\title{
2w45555
}

\section{Quality Control of the Mitochondrion}

Matthew Yoke Wui $\mathrm{Ng}^{1,2}$, Timothy Wai ${ }^{3,{ }^{*}}$ and Anne Simonsen ${ }^{1,2, *}$

${ }^{1}$ Department of Molecular Medicine, Institute of Basic Medical Sciences, University of Oslo, N0372 Oslo, Norway, ${ }^{2}$ Centre for Cancer Cell Reprogramming, Institute of Clinical Medicine, University of Oslo, N-0316, Oslo, Norway, ${ }^{3}$ Institut Pasteur CNRS 3691, 25 Rue du Docteur Roux, Paris, France

${ }^{*}$ Correspondence:

timothy.wai@pasteur.fr

anne.simonsen@medisin.uio.no

Lead contact:

anne.simonsen@medisin.uio.no

Keywords: mitochondria, mitoproteases, UPS, UPRmt, ISR, mitophagy, mitochondrial dynamics, MDVs 


\section{Summary}

Mitochondria are essential organelles that execute and coordinate various metabolic processes in the cell. Mitochondrial dysfunction severely affects cell fitness and contributes to disease. Proper organellar function depends on the biogenesis and maintenance of mitochondria and its $>1000$ proteins, and as a result the cell has evolved mechanisms to coordinate protein and organellar quality control, such as the turnover of proteins via mitochondria-associated degradation, the ubiquitin-proteasome system and mitoproteases, as well as the elimination of mitochondria through mitophagy. Specific quality control mechanisms are engaged depending upon the nature and severity of mitochondrial dysfunction, which can also feedback to elicit transcriptional or proteomic remodeling by the cell. Here, we will discuss the current understanding of how these different quality control mechanisms are integrated and overlap to maintain protein and organellar quality and how they may be relevant for mitochondrial and cellular health.

\section{Introduction}

Mitochondria are specialized organelles that act as metabolic hubs and signaling platforms, involved in an array of essential cellular processes such as ATP production through oxidative phosphorylation (OXPHOS), fatty acid oxidation, calcium buffering, phospholipid synthesis, reactive oxygen species generation and maintenance, ironsulfur cluster biosynthesis, and innate immune signaling (Spinelli and Haigis, 2018). In contrast to the 13 mitochondrial DNA (mtDNA) encoded proteins, more than 1200 nuclear-encoded mitochondrial proteins (NUMPs) are first synthesized in the cytosol and then targeted to various sub-mitochondrial compartments; the outer mitochondrial membrane (OMM), intermembrane space (IMS), inner mitochondrial membrane (IMM) or the mitochondria matrix. It is imperative that these proteins be properly processed, folded, and localized (Wiedemann and Pfanner, 2017), as interference at any point 
along this chain of events is detrimental to the cell. Accordingly, various overlapping and interconnected safeguard mechanisms have evolved to mitigate mitochondrial damage that can occur as a result of external insults such as nutrient deprivation, hypoxia and OXPHOS uncoupling, or as a consequence of aberrant mitochondrial proteostasis. These include protein quality control checkpoints, acting prior to mitochondrial protein import, such as mitochondria associated degradation (MAD) and other processes linked to the Ubiquitin (Ub)-Proteasome system (UPS). Inside mitochondria, mitochondrial proteases (mitoproteases) regulate the quality and function of imported proteins and mtDNA-encoded gene products. Finally, organellar quality control checkpoints that involve the segregation, removal, and turnover of mitochondrial fragments in mitochondria derived vesicles (MDV) or entire organelles (mitophagy) and nuclear transcriptional responses (unfolded protein response of the mitochondria (UPRmt)) are engaged in response to various mitochondrial and cellular signals. Here, we will review these quality control systems and responses (Figure 1) and discuss how the molecular mechanisms of organellar and protein quality control are connected and coordinated.

\section{Quality control of mitochondrial protein import}

The mitochondrial proteome is estimated to contain 1200 proteins in humans (Rath et al., 2020) and around 900-1000 proteins in yeast (Morgenstern et al., 2017, Vögtle et al., 2017). Virtually all mitochondrial proteins are nuclear-encoded and synthesized in the cytosol prior to their targeting and import to mitochondria in a coordinated and regulated manner (Bykov et al., 2020). Cytosolic mitochondrial precursor proteins are kept unfolded by the Hsp70 and Hsp90 family of cytosolic chaperones prior to their delivery to the mitochondria. These precursor proteins often possess a short $\mathrm{N}$-terminal mitochondrial targeting peptide, composed of hydrophobic and positively charged amino acids, facilitating interaction with negatively charged residues on the cytosolic surface of the translocase of outer mitochondrial membrane (TOM) complex (Wiedemann and Pfanner, 2017), the primary import channel for mitochondrial proteins. However, in yeast, precursor proteins can prematurely fold or stall during translocation, as seen when mitochondrial membrane potential is lost (Weidberg and Amon, 2018), leading to 
their accumulation on the OMM or aberrantly elsewhere in the cell, which makes them accessible to the quality control systems in the cytosol (Figure 2).

One such system, MAD is analogous to the endoplasmic reticulum (ER) quality control mechanism called ER-associated degradation (ERAD) (Hwang and Qi, 2018), and facilitates OMM protein ubiquitination and turnover. During MAD, the type II AAA+ ATPase VCP/p97 (Cdc48 in yeast) hydrolyses aberrant proteins from the mitochondrial membrane to facilitate their membrane extraction for degradation by the proteasome (Figure 2, MAD) (Xu et al., 2011), indicating an important role of MAD in mitochondrial homeostasis. Substrates for MAD include factors involved in the maintenance of mitochondrial morphology (Fzo1 in yeast (Cohen et al., 2008), Mitofusins and Mcl-1 in mammals (Tanaka et al., 2010), ER-mitochondrial contact sites (Mdm34p) (Wu et al., 2016b) and protein import (Msp1p, Tomm70p) (Wu et al., 2016b). VCP/p97 and Cdc48 are also capable of removing stalled nascent peptides from cytosolic ribosomes, thus facilitating their degradation by the proteasome (Verma et al., 2013, Defenouillère et al., 2013, Brandman et al., 2012). Cdc48 is recruited to mitochondria in response to oxidative stress (Heo et al., 2010) and its cofactor Doa1 is necessary for the association of the Cdc48 complex to ubiquitinated proteins (Wu et al., 2016b), including IMS and matrix proteins (Liao et al., 2020), although it is unclear how and when these substrates may become ubiquitinated. Interestingly, MAD, but no other quality control mechanism tested, protected yeast cells from paraquat-induced oxidative stress, indicating that $M A D$ is the main player in the clearance of oxidized damaged mitochondrial proteins (Liao et al., 2020).

In yeast, several pathways are involved in the removal of stalled precursor proteins that accumulate in import channels and on the surface of the OMM, promoting their degradation by the cytosolic UPS. Mitochondrial protein translocation-associated degradation (MitoTAD) (Mårtensson et al., 2019) facilitates removal of precursor proteins whose import through the IMM is stalled upon mitochondria depolarization, following treatment with the protonophore CCCP, leading to their accumulation in the TOM complex. Such precursor arrest promotes the interaction between the Ub-like (UBX)-domain-containing protein 2 (Ubx2) and the TOM complex, leading to recruitment 
of Cdc48 and its co-factor Ufd1 to remove arrested precursor proteins and maintain TOM complex function (Mårtensson et al., 2019) (Figure 2, mitoTAD). Ubx2 further interacts with the Cdc48 adaptor protein Vms1, which is itself involved in ribosomeassociated quality control to remove nascent chains from stalled ribosomes (Izawa et al., 2017, Verma et al., 2018, Zurita Rendón et al., 2018), suggesting that the function of Ubx2 expands beyond the surveillance of the TOM complex and highlights the coordination between protein synthesis and import.

The mitochondrial compromised protein response (MitoCPR) (Weidberg and Amon, 2018) involves removal and UPS degradation of stalled precursors destined for the IMS. Such precursors contain an N-terminal mitochondrial targeting signal followed by a hydrophobic "stop-transfer" sequence that facilitates their localization to the IMS. This bipartite signal is removed by proteolytic cleavage, leading to their release into the IMS, thus preventing their further translocation into the mitochondrial matrix (Neupert and Herrmann, 2007). When bipartite protein import is inhibited, precursor proteins accumulate on the mitochondria surface and in mitochondrial translocases, leading to activation of mitoCPR to induce the expression of Cis1 through the transcription factor Pdr3, which in turn recruits the AAA-ATPase Msp1 to the TOM complex to extract nonimported precursor proteins from the OMM surface (Weidberg and Amon, 2018) (Figure 2, mitoCPR). Msp1 is believed to associate with the cytosolic part of translocating precursor proteins to unfold early folded precursors, and if unsuccessful, to target these for proteasomal degradation (Wang et al., 2020). Msp1 is also capable of extracting mistargeted tail-anchored proteins from the OMM, which then get reinserted on the ER membrane, where they are extracted by Cdc48 and sent to the proteasome for degradation (Matsumoto et al., 2019). The mechanisms involved in the mitoTAD and mitoCPR pathways have mainly been elucidated under artificial protein import stress induction in yeast cells and whether these quality control pathways exist in metazoans and can be triggered by physiological stimuli is not known.

Vms1 is also a central component of the ribosome quality control pathway for mitochondrial polypeptides (mitoRQC) in yeast that rescues ribosome-stalled 
polypeptides (Izawa et al., 2017). Vms1, together with E3 ligase Ltn1 and Rqc2, directly bind to 605 ribosomes at the mitochondria surface to facilitate protein import and removal of stalled mitochondrial peptides on cytosolic ribosomes (Izawa et al., 2017). Some mitochondrial proteins are translocated during translation and such cotranslocation can result in formation of ribosome-stalled polypeptides that are inaccessible to the UPS. Such aggregation on the mitochondria involves the addition of C-terminal alanyl/threonine residues (CAT-tails) (Shen et al., 2015) that are generated by Rqc2 and are ultimately toxic to the cell. Vms1 associates with the 60S ribosome to dissociate Rqc2 and prevent CAT-tailing (Su et al., 2019), thus allowing transport of the nascent polypeptide into the mitochondria, where it can be folded or be exposed to the other mitochondrial quality control mechanisms like mito-proteases (see below). Conversely, Ltn1 ubiquitinates C-terminal lysine residues of the stalled polypeptide chain, which then become extracted by Cdc48 for proteasomal degradation (Izawa et al., 2017) (Figure 2, mitoRQC). mitoRQC has not yet been described in mammals, but it is interesting to note that loss of the human homolog of Vms1, ankyrin repeat and zincfinger domain-containing 1 (ANKZF1), decreased mitochondrial integrity, and that ANKZF1 was able to rescue Vms1 deficient yeast cells (van Haaften-Visser et al., 2017), suggesting that ANKZF1 is involved in RQC of mitochondrial surface associated ribosomes, in addition to its well-established roles in global RQC (Verma et al., 2018, Kuroha et al., 2018, Yip et al., 2019). Further supporting this link, ANKZF1 has been shown to translocate to the mitochondrial surface upon $\mathrm{H}_{2} \mathrm{O}_{2}$-induced cellular stress (van Haaften-Visser et al., 2017).

The UPRam is a pathway in yeast that alleviates proteotoxic stress caused by mislocalized mitochondrial proteins by activation of the proteasome and inhibition of protein synthesis (Wrobel et al., 2015) (Figure 2, UPRam). While cytoplasmic protein aggregates typically inhibit the proteasome (Bennett et al., 2005), mitochondrial precursor protein accumulation in the cytosol stimulates proteasomal activity and inhibits protein synthesis in order to reduce the burden of cytosolic precursor proteins (Wrobel et al., 2015). The reason behind the differential influence of cytosolic and mitochondrial proteins on the proteasome is not fully understood. Accumulation of 
cytosolic unfolded precursor proteins can also elicit a much more detrimental response through a yeast apoptotic signaling pathway called the mitochondrial precursor overaccumulation stress (mPOS) (Wang and Chen, 2015) (Figure 2). Interestingly, IMS proteins such as Cox12 and Pet191 have been reported to be retro-translocated to the cytosol through the TOM40 channel (Bragoszewski et al., 2015), which could function to increase the mitochondrial protein abundance in the cytosol in order to initiate UPRam or mPOS. Another cell death mechanism called Mitochondrial stress induced translational termination impairment and protein carboxy terminal extension (MISTERMINATE), described in Drosophila and mammalian cells, is activated during mitochondrial stress, leading to reduced translation termination of nuclear encoded mRNA by impairment of the ribosome recycling ATPase ABCE1 and release factor eRF1. Reduction of ABCE1 and eRF1 activity leads to non-mRNA encoded extension at the C-terminal of mitochondrial proteins such as the complex I subunit NDUFS3, which when accumulated inhibits OXPHOS and is toxic to cells (Wu et al., 2019). Indeed, mitochondrial dysfunction caused by rotenone and CCCP prompted the impairment of translation termination of mitochondrial transcripts through the loss of eRF1 and ABCE1 (Wu et al., 2019). Proteasomal degradation of ABCE1 could possibly be an initiating step in MISTERMINATE, as ABCE1 is K48-polyubiquitinated upon mitochondrial damage (Wu et al., 2018).

\section{The ubiquitin proteasome system in OMM protein quality control}

Mitochondrial protein ubiquitination allows the organelle to respond rapidly to mitochondrial and cellular insults. $\mathrm{Ub}$ is a small protein of 76 amino acids that is conjugated to lysine $(\mathrm{K})$ residues or a wide range of target proteins in a process that involves Ub-activating enzymes (E1), Ub-conjugating enzymes (E2) and Ub ligases (E3), often forming poly-Ub chains (Deol et al., 2019). When conjugated, Ub can alter the function of a protein and can function as binding sites for other proteins with Ubbinding domains. One of the main functions of $\mathrm{Ub}$ is to act as a degradation signal, since proteins tagged with $\mathrm{K} 29$ - and K48-linked polyUb chains are destined for degradation by the proteasome, while proteins linked by K63-linked polyUb chains are 
targeted for degradation by autophagy (discussed below), signal transduction and endocytosis.

Proteins on the cytosolic face of the OMM are under the scrutiny of the UPS. The E3 Ub-ligase MARCH5 (also known as MITOL) facilitates ubiquitination of misfolded proteins on the OMM to initiate their proteasomal degradation (Yonashiro et al., 2009, Sugiura et al., 2011). Additionally, MARCH5 was recently shown to regulate mitochondrial protein import by ubiquitination of mitochondrial precursor proteins on their C-terminal region, thereby facilitating their aggregation and subsequent proteasomal degradation (Phu et al., 2020). This process is counter-regulated by the mitochondrial deubiquitinase USP30, as the depletion of USP30 led to the accumulation of ubiquitinated mitochondrial proteins in the cytosol (Phu et al., 2020). In addition to generating K63-linked polyUb chains during mitophagy, the E3 Ub ligase Parkin also promotes protein import by non-canonical K11 ubiquitination of the TOM complex and may possibly function to re-establish mitochondrial protein transport after mitochondrial damage (Jacoupy et al., 2019).

While mitochondrial membranes physically separate the UPS in the cytosol from most mature mitochondrial proteins, it is interesting to note that ubiquitinated matrix and IMM proteins have been identified in HeLa cells (Lavie et al., 2018), mouse heart (Jeon et al., 2007) and isolated mitochondria from yeast (Lehmann et al., 2016). How and when these proteins become accessible for ubiquitination is not clearly understood - it is possible that proteins are ubiquitinated prior to their mitochondrial import, although it is unclear whether large Ub moieties would sterically inhibit translocation across import channels. Ub-conjugating enzymes have been observed in mitochondria (Schwartz et al., 1992, Patil et al., 2019), suggesting they might contribute to the ubiquitination of proteins in organello. Mitochondrial function also appears to be regulated by the UPS, as mitochondrial proteins related to energy production, including components of all four complexes of the OXPHOS machinery and the ATP-synthase, are substrates for ubiquitination (Jeon et al., 2007, Lavie et al., 2018). The implication of Ub-conjugation on the OXPHOS machinery is not fully elucidated, but it appears that succinyl 
dehydrogenase subunit $A$ (SDHA) is K48 polyubiquitinated and degraded by the UPS during times of low mitochondrial metabolism (Lavie et al., 2018). Extrapolated, we can expect other components of the OXPHOS machinery to also be regulated by the UPS depending on mitochondrial metabolic status.

\section{Mitochondrial Proteases}

Upon transport into the mitochondrion, proteins remain under the surveillance of proteases that are tasked with both quality control and regulatory proteolysis, residing within the different sub-compartments of the mitochondrion (Figure 3 ). Historically known as surveyors of protein quality, mitoproteases have been regarded as the first line of defense in mitochondrial quality control (Leonhard et al., 1999). Beyond aberrant protein turnover, mitoproteases regulate proteolysis (cleavage or degradation) of substrates involved in mitochondrial dynamics, mitophagy, apoptosis, lipid biosynthesis, calcium buffering, OXPHOS, and protein import (Deshwal et al., 2020). A number of regulatory inputs can modulate the activities of mitoproteases, while conversely, disruption of mitoproteases signals the engagement of other mitochondrial and cellular quality control responses (Shpilka and Haynes, 2018). There are 18 catalytically proficient mitoproteases that exclusively localize to the mitochondria and whose bacterial origins can be traced from structural, topological, and functional perspectives (Deshwal et al., 2020). Of these, we will focus on the best-studied ATP-dependent proteases of which there are 4 that employ ATP hydrolysis through their AAA+ domains to execute both quality control and regulatory proteolysis: LONP, CLPXP, the $m-A A A$ protease, and the $i$-AAA protease, all of which form homo- or hetero-oligomeric ring-like structures comprised of an internal ATP-dependent proteolytic chamber (Deshwal et al., 2020), and the mitochondrial rhomboid protease PARL (Presenilin-associated rhomboid-like protein).

LONP1 forms a homo-hexameric complex in the matrix and regulates mitochondrial gene expression, mtDNA maintenance, and OXPHOS. LONP1 degrades oxidatively damaged Aconitase, an enzyme of the Krebs cycle (Bota and Davies, 2016). It also 
regulates turnover of TFAM (Matsushima et al., 2010), a core mtDNA nucleoid protein required for the packaging (Kaufman et al., 2007), maintenance (Gustafsson et al., 2016), and expression (Litonin et al., 2010) of mtDNA (Figure 3, mtDNA maintenance). Furthermore, it is required for the maturation of several proteins involved in mitochondrial gene expression (SLIRP, MTERFD3 and FASTKD2), mtDNA replication (SSBP) and the ATP-dependent mitoprotease CLPX (Zurita Rendón and Shoubridge, 2018, Lagouge et al., 2015) (Figure 3, mtDNA expression). Finally, it degrades COX4-1 under hypoxic conditions to promote the assembly of COX4-2, a structural subunit of the terminal electron transport chain (ETC) enzyme cytochrome $c$ oxidase, thereby optimizing electron transfer and oxygen consumption (Hao et al., 2018) (Figure 3, OXPHOS complexes). Given the crucial role of LONP1 in mitochondrial function, it is not surprising that patients harboring mutations in LONP1 exhibit OXPHOS deficiencies observed in other mitochondrial diseases (Peter et al., 2018). LONP1 mutations cause CODAS syndrome, manifested by cerebral, ocular, dental, auricular, and skeletal anomalies. Further exemplifying its importance, homozygous deletion of Lonp1 leads to embryonic lethality, likely due to the inability to meet the energy demands of embryonic development (Quirós et al., 2014). On the other hand, overexpression of Lon is associated with improved cardiac function in mice and increased lifespan in podospora (Luce and Osiewacz, 2009). Whether phenotypes observed in vivo reflect defects in regulatory cleavage and/or quality control of LONP1 substrates is unknown.

The Caseinolytic mitochondrial matrix peptidase (CLPXP) evolved from the bacterial orthologue ClpP (Bross et al., 1995), and is composed of seven CLPP subunits and six CLPX subunits. Similar to the protein quality control role of its bacterial ancestor, CLPXP is also reported to participate in selectively removing and degrading damaged subunits of Complex I (Szczepanowska et al., 2020) and Complex II (Seo et al., 2016) (Figure 3, OXPHOS complex), thereby preserving bioenergetic capacity, obfuscating the need to reassemble large macromolecular complexes from scratch. Additionally, CLPXP is implicated in the regulation of mitochondrial gene expression by controlling key factors required for mitochondrial RNA (mtRNA) stability (Matsushima et al., 2017) and protein synthesis (Szczepanowska et al., 2016) via the regulatory proteolysis of 
ERAL1, a negative regulator of mitoribosome assembly (Chatzispyrou et al., 2017) (Figure 3, mtDNA expression). Notably, disruption of either CLPXP (Jenkinson et al., 2013) or ERAL1 (Chatzispyrou et al., 2017) are associated with Perrault syndrome, a disease characterized by ovarian dysgenesis, sensorineural hearing impairment and is sometimes accompanied by progressive cerebellar ataxia and intellectual deficit. In mice, whole-body deletion of Clpp recapitulates the primary features of Perrault syndrome accompanied by inflammation and T cell activation (Gispert et al., 2013). Interestingly, dominant mutations in CLPXP can also cause Erythropoietic protoporphyria (Yien et al., 2017) manifesting in photosensitivity and macrocytic anemia. The molecular basis for phenotypic variation is unclear.

The $m-A A A$ protease is an IMM-embedded ATP-dependent protease responsible for the proteolysis of resident matrix proteins and integral IMM proteins facing the matrix. It forms a homo- or hetero-hexameric complex, comprised of either SPG7 and/or AFG3L2 and further assembles into a complex with Prohibitin 1 (PHB1) and -2 (PHB2) of the SPFH (stomatin, prohibitin, flotillin, $\mathrm{HfIC} / \mathrm{K}$ ) superfamily of membrane anchored scaffold proteins (Osman et al., 2009). In mice, an additional subunit Afg3l1 can substitute for either Spg7 or Afg3l2 in hetero-oligomeric complexes. In addition to its quality control function by turnover of misfolded or damaged proteins to ensure OXPHOS functionality (König et al., 2016), the m-AAA protease has been shown to maintain energy production by regulating the assembly of the mitoribosome via its substrate MrpL32, an essential subunit of the large mitochondrial ribosome (Nolden et al., 2005) (Figure 3, mtDNA expression). Additionally, mitochondrial calcium uptake is controlled via proteolysis of the regulatory subunit of the mitochondrial calcium uniporter (MCU) (Sancak et al., 2013), executed by the m-AAA protease (Figure 3, Calcium homeostasis). In the absence of proteolytic regulation, Essential MCU regulator (EMRE) accumulates and assembles with MCU to form a constitutively active uniporter complex that overloads mitochondria with calcium, which triggers the opening of the mitochondrial permeability transition pore (MPTP) in the IMM and programmed cell death (König et al., 2016). 
The $i$-AAA protease, like the m-AAA protease, evolved from the bacterial orthologue FtsH and is composed of 6 subunits of Yme1 (for Yeast mitochondrial DNA escape -1), known as YME1L1 in humans (Wai and Langer, 2013). The $i$-AAA protease is imbedded in the IMM in a proteolytic complex anchored by the scaffold protein Stomatin-like protein 2 (SLP2), which also anchors the mitochondrial processing peptidases, OMA1 and PARL. Just as the PHB complex regulates the proteolytic activity of the m-AAA protease, so does SLP2 influence the proteolytic regulation of its interacting proteases (Wai et al., 2016). The i-AAA protease degrades damaged and misfolded proteins (Leonhard et al., 1999) and performs regulatory cleavage of a growing number of IMS and IMM resident proteins that are directly required for mitochondrial dynamics, lipid transfer, and protein import (MacVicar et al., 2019). In mammals, YME1L is one of two processing peptidases that cleave OPA1 from a long (L-OPA1) to a short (S-OPA1) form, thereby regulating the balance between mitochondrial fusion and fission (MacVicar and Langer, 2016) (Figure 3, Mitochondrial dynamics). OMA1 is also a substrate under the purview of YME1L (Rainbolt et al., 2016). OMA1, initially named for its overlapping activity with the m-AAA protease, is a metalloprotease that is hyperactivated under a number of stress conditions, but also executes the cleavage of IMS and IMM substrates under basal conditions. In yeast, Oma1 is involved in the turnover of mutant MT-CO1, which is encoded by mtDNA (Bohovych et al., 2014, Khalimonchuk et al., 2012). In mammals, OMA1 cleaves L-OPA1 to S-OPA1 to regulate mitochondrial dynamics, yet when challenged with depolarizing agents (Baker et al., 2014, Head et al., 2009, Ehses et al., 2009), inhibitors of the respiratory chain, or mutations in mitochondrial disease genes affecting the $i$-AAA protease (Anand et al., 2014, Hartmann et al., 2016, Song et al., 2007) like m-AAA protease (Ehses et al., 2009), Acyl Glycerol Kinase (Vukotic et al., 2017) and HTRA2 (Oláhová et al., 2017), OMA1 activity is increased leading to proteolysis and degradation of L-OPA1, thereby blocking mitochondrial fusion. YME1L is also involved in the proteomic remodeling of the inner membrane proteome, in part through the turnover of structural components of the TIM23 protein import complex of the IMM (MacVicar et al., 2019), TIMM17A (Rainbolt et al., 2015, Rainbolt et al., 2013) and ROMO1, a partner of TIM23 (Richter et al., 2019) (Figure 3, Protein import). Finally, the i-AAA protease controls the regulatory 
turnover of the phospholipid transfer protein PRELID1, which shuttles the cardiolipin (CL) lipid precursor phosphatidic acid (PA) from the OMM to the IMM (Figure 3, Lipid metabolism). PRELID1 defects result in $\mathrm{CL}$ deficiency, mitochondrial fragmentation and apoptotic sensitivity (Potting et al., 2013), highlighting the importance of maintaining a defined phospholipid composition in the IMM for mitochondrial integrity. Recent proteomic studies from the Langer group have uncovered a number of IMS and IMM proteins as putative substrates of $\mathrm{YME} 1 \mathrm{~L}$, including proteins involved in solute transport, protein import, lipid metabolism, OXPHOS, and cell death (MacVicar et al., 2019). Mutations in YME1L cause a neurodevelopmental disease characterized by developmental delay, hearing loss, and brain and optic atrophy (Hartmann et al., 2016). Like LONP1, Yme1/ deletion is embryonic lethal, yet conditional mouse models are initially viable. However, neuron-specific deletion of $Y m e 1 /$ causes axon degeneration and ocular dysfunction (Sprenger et al., 2019) while cardiomyocyte-specific deletion in mice causes cardiomyopathy and heart failure (Wai et al., 2015). Mitochondrial fragmentation can be suppressed by additional ablation of Oma1, which rescues cardiac function in the heart specific Yme1/ KO mice and argues for an importance of mitochondrial morphology for cardiac function. However, Oma1 ablation in brain-specific Yme1/ KO mice improves mitochondrial morphology, but fails to prevent axon degeneration and locomotor dysfunction, highlighting tissue-specific importance of mitochondrial dynamics regulation. In vivo, Oma1 deletion protects against neurodegeneration (Korwitz et al., 2016), acute kidney injury (Xiao et al., 2014), and cardiomyopathy (Acin-Perez et al., 2018, Wai et al., 2015), supporting the notion that rebalancing mitochondrial dynamics is beneficial for organ function. Recently, Oma1 was identified as a critical regulator of DELE1, a mitochondrial protein whose cleavage promotes its export from mitochondria to orchestrate ATF4-mediated stress responses (Guo et al., 2020, Fessler et al., 2020). Under stress conditions, OMA1 is also involved in the proteolytic cleavage of PGAM5 (Wai et al., 2016), a mitochondrial serine/threonine phosphatase linked to programmed cell death, mitochondrial dynamics, and inflammation (Kang et al., 2015, He et al., 2017, Sekine et al., 2016, Wang et al., 2012). 
The serine protease, PARL localizes to the IMM where it integrates into the SPY complex (consisting of SLP2, PARL and YME1L) (Wai et al., 2016). Rhomboid proteases perform intermembrane cleavage using a catalytic dyad composed of serine and histidine that are contributed by different transmembrane domains. As such, the yeast orthologue of PARL, Pcp1 is required for the proteolytic maturation of Mgm1 (Opa1 in mammals) and is essential for mitochondrial membrane fusion and respiration (Herlan et al., 2003, McQuibban et al., 2003). PARL expression is able to rescue Pcp1 mutant cell defects, implying functional homology, despite significant substrate specificity divergence. In mammals, PARL does not cleave OPA1 (which is processed by YME1L or OMA1) and is required for the proteolytic cleavage of a number of substrates involved in lipid transfer (STARD7) (Yang et al., 2017), mitophagy (PINK1) (Deas et al., 2010), apoptosis (SMAC/diablo) (Saita et al., 2017), necroptosis (PGAM5) (Sekine et al., 2012) (Figure 3, Cell death regulation), and complex III of the respiratory chain (TTC19) (Spinazzi et al., 2019). Whole-body Parl knockout mice are born normal, yet suffer from growth retardation, and atrophy of muscle, spleen and thymus, highlighted by increased apoptosis of immune cells (Cipolat et al., 2006). Brain-specific Parl deletion causes encephalomyopathy and neuronal necrosis, accompanied by defects in Complex III and altered processing of PGAM5 and PINK1 (Spinazzi et al., 2019). Still, it remains to be determined which of the known PARL substrate(s), if any, are causal for the manifestation of these phenotypes, since deletion of either PINK1 or PGAM5 does not affect the PARL-deficient phenotypes in vivo.

\section{Mitophagy}

Autophagy is a conserved process that involves sequestration of cytosolic cargo into double-membrane vesicles (autophagosomes) that eventually fuse with lysosomes, leading to the degradation of the sequestered material. Autophagosome biogenesis involves a cascade of signaling and recruitment events that can be initiated by an array of conditions, such as starvation, hypoxia and ER stress (Dikic and Elazar, 2018). In mammals, such stressors generally activate the ULK1 complex (consisting of ULK1, ATG13, FIP200 and ATG101), to initiate the pathway leading to lipid conjugation of 
ATG8 proteins that line the autophagosome membrane. Quality control at the organelle level can be achieved by selective autophagy of mitochondria, in a process commonly referred to as mitophagy (Lemasters, 2005) (Figure 4). Mitophagy is important to maintain the quality of the mitochondrial pool and for regulation of mitochondrial abundance in response to environmental cues such as hypoxia (Quinsay et al., 2010, Tracy et al., 2007), oocyte fertilization (Shitara et al., 2000), erythroid cell maturation and stem cell pluripotency (Takano-Ohmuro et al., 2000, Diwan et al., 2007, Ho et al., 2017). Several gene products required for mitophagy have been found to be mutated in neurodegenerative diseases such as Parkinson disease (PD) (Kitada et al., 1998, Valente et al., 2004), Huntington disease (Khalil et al., 2015) and Alzheimer disease (Ye et al., 2015), as well as cancer (Bernardini et al., 2017), giving rise to the notion that dysregulation of mitophagy contributes to disease. During mitophagy, mitochondria are specifically sequestered into autophagosomes via receptor proteins that link mitochondria to the autophagy membrane (Dikic and Elazar, 2018). Such autophagy receptors can either interact with ubiquitinated OMM proteins or themselves be integrated into the OMM, but have in common the ability to bind to ATG8 homolog proteins of the LC3 and GABARAP subfamilies in the autophagy membrane via a specific LC3 interacting region (LIR) (Johansen and Lamark, 2020). In mammals, mitophagy is generally divided into two main functionally distinct groups, based the requirement for the kinase PINK1 and the Ub E3 ligase Parkin, often referred to as PINK1/Parkin-dependent and PINK1/Parkin-independent mitophagy. The PINK1/Parkindependent pathway can be initiated by a loss of mitochondrial membrane potential (Narendra et al., 2008), while PINK1/Parkin-independent mitophagy does not require loss of the mitochondrial membrane potential (Allen et al., 2013). PINK1/Parkindependent and -independent pathways utilize different sets of autophagy receptors. It is assumed that the autophagy receptors involved in PINK1/Parkin-dependent mitophagy are cytosolic proteins that interact with ubiquitinated OMM proteins via Ub-binding domains, while receptors involved in PINK1/Parkin-independent mitophagy are integral mitochondrial proteins that interact directly with ATG8 family proteins. While there are clear differences between the PINK1/Parkin-dependent and -independent pathways, crosstalk between the two pathways has been reported. An example illustrating this is 
the E3 ubiquitin ligase ARIH1 that requires PINK1 to regulate Parkin-independent mitophagy (Villa et al., 2017).

\section{PINK1/Parkin-dependent mitophagy}

In healthy, import-competent mitochondria harboring a negative membrane potential, PINK1 is constantly translocated into the mitochondria where it is cleaved by the mitochondrial processing peptidases MPP (Greene et al., 2012) and PARL (Jin et al., 2010, Deas et al., 2010) in the matrix and subsequently retro-translocated to the cytosol to be degraded by the $\mathrm{N}$-end rule pathway (Yamano and Youle, 2013) (Figure 4a). In contrast, PINK1 accumulates on the OMM upon depolarization of the mitochondrial membrane potential, when translocation of precursors into the mitochondria is stalled (Figure 4b), allowing the formation of a TOM-PINK1 complex (Lazarou et al., 2012) that promotes the recruitment of Parkin, which in turn ubiquitinates OMM proteins. MARCH5 ubiquitylates OMM proteins to form the "seeding" Ub chains for Parkin recruitment (Koyano et al., 2019). Thereafter, PINK1 phosphorylates Ub chains to further stimulate the mitochondrial recruitment of Parkin (Shiba-Fukushima et al., 2014, Okatsu et al., 2015, Wauer et al., 2015) and its E3 Ub ligase activity (Kane et al., 2014). Interestingly, the autophagy receptor p62/SQSTM1 was recently shown to recruit an E3 Ub ligase complex, consisting of Keap1 and Rbx1 to promote mitochondrial ubiquitination in the absence of Parkin in the liver of mice (Yamada et al., 2018). The generation of phosphorylated poly-Ub chains on OMM proteins leads to the recruitment of autophagy receptors that contain Ub binding domains, such as OPTN (Wong and Holzbaur, 2014) and NDP52 (also known as CALCOCO2) (Lazarou et al., 2015) to the mitochondrial surface. Using HeLa cells, lacking all five sequestosome-like receptors (SLRs) (TAX1BP1, NDP52, NBR1, p62/SQSTM1 and OPTN) as a template for rescue experiments, it was found that only NDP52 and OPTN were absolutely required for PINK1/Parkin-dependent mitophagy (Lazarou et al., 2015). However, other reports have implicated p62 in mitophagy in macrophages (Zhong et al., 2016) and leukemia cells (Nguyen et al., 2019), suggesting different cell or tissue specificities with regards to essential mitophagy receptors. Equally important, 4-Nitrophenylphosphatase domain and non-neuronal SNAP25-like protein homolog 1 (NIPSNAP1) and 2 (NIPSNAP2) 
were recently shown to be required for PINK1/Parkin-dependent mitophagy by facilitating mitochondrial recruitment of the SLRs, the autophagy-linked FYVE protein (ALFY) and human ATG8 proteins (Princely Abudu et al., 2019). Similar to PINK1, NIPSNAP1/2 accumulate on the OMM upon mitochondria depolarization, thus acting as a "eat me" signal for mitophagy by interacting with mitophagy receptors such as NDP52 and p62 to induce PINK1/Parkin mitophagy (Princely Abudu et al., 2019).

Most of our understanding of the PINK1/Parkin-dependent mitophagy pathway originated from studies where harsh depolarizing agents were used to trigger mitophagy. However, such chronic depolarization of mitochondria observed with the use of protonophores (e.g. FCCP, CCCP) or OXPHOS inhibitors (e.g. Oligomycin, Antimycin A) poorly mimic physiological or pathophysiological situations. Indeed, the importance of PINK1 and Parkin for in vivo mitophagy is less clear, with differences observed across species, tissues, and cell lines. Depletion of PINK1 and Parkin does not affect basal mitophagy in Drosophila (Lee et al., 2018a, Kim et al., 2019) or mice (McWilliams et al., 2018). Moreover, PINK1 is dispensable for Parkin activation upon mitochondrial depolarization in cardiac myocytes from mice (Kubli et al., 2015) and acute exerciseinduced mitophagy in mice does not require the stabilization of PINK1 on the mitochondria (Drake et al., 2019). On the contrary, PINK1 and Parkin were required for hypoxia induced mitophagy in the wing discs of L3 larvae (Kim et al., 2019), highlighting possible tissue or organism specific influences on mitophagy. Furthermore, mitochondrial stress leads to elevated levels of DAMPs in the form of mtDNA and subsequent induction of STING-mediated type I interferon response in mice lacking PINK1 or Parkin, indicating that PINK1 and Parkin are required in vivo to remove damaged mitochondria and to regulate innate immunity (Sliter et al., 2018). Nevertheless, all these point towards the possibility of alternative mechanisms, parallel to the PINK1/Parkin-dependent mitophagy pathway in whole organisms.

\section{PINK1/Parkin-independent mitophagy}

PINK1/Parkin-independent mitophagy is induced through receptors that are anchored on the cytosolic face of the OMM such as BNIP3 (Quinsay et al., 2010), BNIP3L 
(Sandoval et al., 2008, Schwarten et al., 2009), BCL2-L13 (Murakawa et al., 2015), FUNDC1 (Liu et al., 2012, Chen et al., 2016) and FKBP8 (Bhujabal et al., 2017) in humans and Atg32 (Okamoto et al., 2009) in yeast (Figure 4d). In yeast, the OMM protein Atg32 (yeast homologue of BCL2L13) interacts with Atg8 and Atg11 to mediate mitophagy (Okamoto et al., 2009). The expression of membrane receptors like BNIP3L and BNIP3 are upregulated upon the stabilization of HIF1 1 , during hypoxia (Bellot et al., 2009) and iron depletion (Allen et al., 2013). Mitophagy receptors can also be regulated by phosphorylation on their LIR motifs, as seen for FUNDC1 (Wu et al., 2014, Liu et al., 2012, Chen et al., 2014), BNIP3L (Rogov et al., 2017) and BNIP3 (Zhu et al., 2013), which controls their affinities towards ATG8 proteins. BCL2-L-13 is the mammalian homologue of yeast Atg32 that is involved in mitochondrial fragmentation and mitophagy (Murakawa et al., 2015), and is able to substitute Atg32 to a limited extent by promoting mitophagy in otherwise mitophagy-deficient yeast cells lacking ATG32 (Murakawa et al., 2015). Atg32 is proteolytically cleaved by the mitoprotease Yme1 ( $i$ AAA protease), thereby regulating its interaction with Atg11 to induce mitophagy (Wang et al., 2013), illustrating the importance of mitoproteases in the regulation of organelle quality control. Yet in mammals, there is no evidence to suggest that YME1L impacts mitophagy. Both membrane-anchored and cytosolic mitophagy receptors associate to the cytosolic face of the OMM. However, should the integrity of the OMM be disrupted such that the IMS is exposed the cytosol, proteins and lipids within the IMS can also associate with the autophagy machinery. The IMM scaffold protein PHB2 (Wei et al., 2017) and the IMM enriched phospholipid CL (Chu et al., 2013, Shen et al., 2017) are elements of the IMM that are both capable of direct interaction to LC3 and consequently function as autophagy receptors in the IMM (Figure 4e), possibly upon OMM rupture.

\section{Mitophagosome biogenesis}

The membrane origin of the autophagosome has been a long-standing issue. While early autophagic structures seem to originate from ER membranes that are closely associated to the mitochondria at regions referred to as mitochondria associated membrane (MAMs) during starvation-induced autophagy (Hamasaki et al., 2013, YläAnttila et al., 2009), the origin of the mitophagosome membrane has been less well 
understood. Recent evidence suggests that the autophagosome membrane also forms at MAMs following induction of mitophagy (Gelmetti et al., 2017, Zachari et al., 2019), in a manner involving de novo membrane formation around the mitochondrion to be degraded (Vargas et al., 2019). This is supported by observations of recruitment of the autophagy-initiating kinase ULK1 to the mitochondria during hypoxia and protonophoremediated mitophagy (Wu et al., 2014), as well as recruitment of early core autophagy proteins (ULK1, ATG14 and DFCP1) to depolarized mitochondria (Itakura et al., 2012). Surprisingly, mitophagy can still occur in the absence of Atg13 in yeast (Okamoto et al., 2009) despite it being an essential member of the yeast Atg1 complex (the mammalian orthologue of ULK1) required for starvation-induced autophagy. In contrast, a recent report found that ATG13, but not ULK1/2 is necessary for the induction phase of mitophagosome formation in mammalian cell lines (Zachari et al., 2019). Thus, activation of the Atg1/ULK1 complex seems to differ depending on the type of autophagy and model organism being studied. It was recently shown that the mitophagy receptors NDP52 and OPTN1, in addition to interacting with ubiquitinated OMM proteins and ATG8 proteins, facilitate recruitment of the early autophagy machinery required for de novo synthesis of the autophagosome membrane at the mitochondria (Lazarou et al., 2015, Vargas et al., 2019, Yamano et al., 2020) . NDP52 interacts with the ULK1 complex subunit Focal Adhesion Kinase Family interacting protein of 200kDa (FIP200) (Vargas et al., 2019) and OPTN1 binds ATG9A (Yamano et al., 2020). ATG8 proteins facilitate further ubiquitin-independent recruitment of OPTN and NDP52 to the growing autophagosome membrane (Padman et al., 2019), thereby amplifying mitophagosome formation. It is interesting to note that de novo autophagosome biogenesis around the mitochondria can occur in cells lacking LC3 and GABARAP proteins, but these proteins are required for fusion of mitophagosomes with lysosomes (Vargas et al., 2019, Nguyen et al., 2016). Notably, mitochondria in neurons are quickly sequestered into non-acidic organelles where they remain for hours before finally fusing with the lysosome to be degraded, suggesting that while mitophagy sequestration into autophagosomes is efficient, the rate limiting step of mitophagy lies in the acidification of the lysosomes (Evans and Holzbaur, 2020). 
It is difficult to imagine how elongated mitochondria can be encapsulated in autophagosomes of a limited size. Indeed, it was previously observed that mitochondria can be turned over in piecemeal fashion whereby small Parkin-positive mitochondrial fragments are delivered to the autophagosome at ER-Mitochondria contact sites (Yang and Yang, 2013). Corroborating this, proximity labelling with apex-tagged human ATG8 proteins revealed that the OMM protein MTX1 directly interacts with LC3C and p62 to recruit mitochondrial fragments to the autophagosome in a piecemeal manner in the absence of external mitophagy stimuli (Le Guerroué et al., 2017) (Figure 4e). While piecemeal mitophagy and MDVs (discussed below) both involve the delivery of mitochondrial cargo in vesicles to the lysosomes in a DRP1-independent manner, the enrichment of oxidized mitochondrial proteins in LC3C vesicles was not observed, and thus cargo differences may distinguish piecemeal mitophagy from oxidative stress induced MDV formation (Le Guerroué et al., 2017).

\section{Mitochondrial derived vesicles (MDVs)}

MDVs are small vesicles of $70-100 \mathrm{~nm}$ in diameter that originate from the OMM and selectively incorporate mitochondrial cargo. They were first identified as vesicles that transport Mitochondrial E3 Ubiquitin Protein Ligase 1 (MUL1, also referred to as MAPL), to peroxisomes (Neuspiel et al., 2008, Braschi et al., 2010), but we now know that there are diverse MDV subpopulations containing distinct cargo, being selectively delivered to different destinations including multivesicular bodies or lysosomes (Soubannier et al., 2012a). Reflecting this, MDVs are made up of either single or double membranes of OMM or both OMM and IMM origin (Figure 1f), possibly containing different, functionally distinct cargos (Sugiura et al., 2014). A subset of MDVs contains MUL1/MAPL but lack $\Delta \Psi$, and another subset that maintain $\Delta \Psi$ but did not have MUL1/MAPL, while yet another subset contained TOMM20 but not MUL1/MAPL (Neuspiel et al., 2008). MDVs are formed under normal conditions and can be upregulated in response to stress induced by the complex III inhibitor Antimycin A, the cytostatic chemotherapeutic doxorubicin, $\mathrm{H}_{2} \mathrm{O}_{2}$ (Cadete et al., 2016) and hypoxia ( $\mathrm{Li}$ et al., 2020), and may affect different cellular functions such as peroxisome biogenesis and antibacterial defense 
(Abuaita et al., 2018). MDVs form in a DRP1-independent manner (Neuspiel et al., 2008) suggesting that fission events are not a prerequisite for MDV formation. However, it appears that MDV formation and mitophagy initiation may share some regulators, as PINK1 and Parkin are involved in the biogenesis of MDVs destined for the lysosomes (McLelland et al., 2014, Ryan et al., 2020). Moreover, the autophagy related SNARE protein Syntaxin17 is also required for the fusion of MDVs to endolysosomes and is itself present on the mature MDV surface (McLelland et al., 2016). Nevertheless, MDVs are formed and delivered to the lysosomes independently of the autophagy genes Atg5 and Becn1, supporting the notion that the MDV pathway is distinct from mitophagy (McLelland et al., 2014). Whether mitophagy and MDVs are functionally redundant (even partially) in the context of organellar or protein quality control remains unexplored, but it is assumed that MDVs occur at baseline housekeeping levels while mitophagy is stimulated upon stress (Sugiura et al., 2014). MDV-like structures, referred to as mitochondrial-derived compartments (MDCs) have been described in yeast (Hughes et al., 2016). Selected mitochondrial proteins, such as Tom70 and Cox7 are sorted into MDCs in a Dnm1-dependent manner. However, in contrast to MDVs, MDC formation require the autophagy proteins Atg5 and Vam3 (Hughes et al., 2016).

Electron tomography revealed an upregulation in the formation of MDVs in isolated mouse heart perfused with chloroquine and Antimycin A, indicating that MDVs are rapidly upregulated in response to mitochondrial insults (Cadete et al., 2016). Elegant electron and light microscopy imaging revealed the presence of MDVs in the cells of rat, mice, Drosophila and planarian neurons, further representing physiological evidence for the presence of MDVs in different organisms (Yao et al., 2020). The biological significance of MDVs is not completely understood, but current evidence points towards a mito-protective role. In cell-free mitochondrial budding experiments, MDVs formed upon mitochondrial stress were enriched with oxidized proteins (Soubannier et al., 2012b), indicating that MDVs can function as an apparatus for the removal of damaged oxidized proteins without whole-sale turnover of the entire organelle. Indeed, proteomic studies in mice using heavy water labeling of cardiac or hepatic mitochondrial proteomes have revealed dramatic differences in half-lives of proteins belonging to the 
same macromolecular complexes or submitochondrial compartments, which cannot be explained by turnover of entire organelles under basal conditions (Kim et al., 2012). Whether MDVs and/or mitochondrial proteases are responsible for this heterogeneity is unknown. In cardiomyocytes, MDV formation is stimulated by hypoxia, possibly as a mechanism to alleviate mitochondrial damage during ischemic myocardial damage as MDV formation was found to be inversely correlated with myocyte apoptosis ( $\mathrm{Li}$ et al., 2020). Further supporting the protective properties of MDVs, exogenous supplementation of MDVs mitigated hypoxia induced apoptosis by increasing $\mathrm{Bcl}-2$ protein levels ( $\mathrm{Li}$ et al., 2020). While still a relatively early field of mitochondrial research, MDVs are proving themselves to be important players in mitochondrial biology and quality control.

\section{Regulation of mitochondrial morphology}

Mitochondria morphology is influenced by an array of factors such as respiratory status, apoptosis induction, and proteotoxic stress, possibly in order to adapt mitochondria to cellular challenges. Mitochondrial morphology vary widely across cell types, reflecting the different metabolic demands and structural constraints of these cells and tissues (Vafai and Mootha, 2012). A number of structural and functional parallels can be drawn between membrane dynamics of mitochondria and bacteria (Pernas and Scorrano, 2016) and the early genetic regulation of mitochondrial dynamics was first worked out in yeast (Shaw and Nunnari, 2002). At the molecular level, mitochondrial morphology is defined by opposing events of fission and fusion of mitochondrial membranes (Figure 5). In mammals, mitochondrial fusion is mediated by dynamin-like GTPases: Mitofusin 1 and 2 (MFN1 and MFN2, respectively) on the OMM, and optic atrophy 1 (OPA1) on the IMM (Chen et al., 2003, Cipolat et al., 2004, Olichon et al., 2003). While IMM fusion is coordinated with OMM fusion, these processes are functionally separable (Chen et al., 2003, Cipolat et al., 2004, Frezza et al., 2006).

OMM fusion in mammals is performed by MFN1 and MFN2, which have partially overlapping functions and exist at contact sites between two adjacent mitochondria in 
homo or heterotypic complexes (Giacomello et al., 2020) (Figure 5b). In yeast, a single mitofusin, Fzo1, catalyzes OMM fusion. Mfn1 knockout in mouse embryonic fibroblasts (MEF) induces mitochondrial fragmentation, while Mfn2 knockout MEFs exhibits swollen spherical mitochondria. This difference can be explained by the fact that MFN1 has a greater guanosine triphosphate (GTP)-dependent membrane tethering activity (Ishihara et al., 2004). Beyond mitochondrial fusion, MFN2 has been proposed to be a key regulator of the mitochondria-ER contact sites tethering (de Brito and Scorrano, 2008), although this claim has been challenged (Naon et al., 2016, Naon et al., 2017).

IMM fusion occurs downstream of OMM fusion and is mediated by OPA1 (Figure 5b). OPA1 is functionally dependent on MFN1 since OPA1 overexpression can rescue mitochondrial fragmentation caused by the loss of MFN2, but not MFN1. Indeed, genetic loss of OPA1 leads to mitochondrial fragmentation its overexpression induces mitochondria elongation (Cipolat et al., 2004). OPA1 is the mammalian orthologue of Mgm1p, the dynamin-like GTPase originally described in baker's yeast as an essential fusion protein (Sesaki et al., 2003) and like Mgm1p, is inserted into the IMM with its Nterminus in the matrix followed by a transmembrane domain, exposing the majority of the protein to the IMS (Faelber et al., 2019). OPA1 harbors sites for proteolytic cleavage by mitoproteases that are essential for its maturation and activities in mitochondrial fusion (Anand et al., 2014, Song et al., 2007), cristae shaping (Cipolat et al., 2004, Lee et al., 2017, Olichon et al., 2003), and mitochondrial DNA maintenance (Elachouri et al., 2011).

OMM fission (Figure $5 \mathrm{c}$ ) is a multi-step process beginning with DRP1 (Dnm1 in yeast), a large GTPase that is recruited from the cytosol to OMM foci that accumulate at respective constriction sites (Labrousse et al., 1999, Pitts et al., 1999). The importance of DRP1 in membrane fission is exemplified by the drastic elongation of both mitochondria and peroxisomes in DRP1 depleted cells (Koch et al., 2003). DRP1 does not bind membrane phospholipids directly and its OMM binding requires metazoanspecific adaptor proteins such as mitochondrial fission factor (MFF) (Gandre-Babbe and van der Bliek, 2008) and mitochondrial dynamics proteins 49 and 51 (MiD49 and 
MiD51) (Palmer et al., 2011, Losón et al., 2013). First discovered in yeast, Dnm1 (Otsuga et al., 1998) requires adaptors Mdv1 and Caf4, which bind directly to Fis1 to promote mitochondrial division (Griffin et al., 2005, Tieu et al., 2002). In humans, FIS1 was initially proposed to be an adapter for DRP1, yet a number of subsequent, conflicting studies regarding its relevance for mitochondrial fission in mammals have called into question its true function for mitochondrial dynamics (Jacobi et al., 2015, Losón et al., 2013, Onoue et al., 2013, Osellame et al., 2016, Palmer et al., 2011, Yu et al., 2019).

Organellar contacts with mitochondria are important platforms for mitochondrial fission. Cryo-EM studies in yeast and mammalian cells showed ER tubules encircling the mitochondria at so-called ER-mitochondrial contact sites, causing pre-constriction around the mitochondrion involving ER resident protein INF2 and Spire1C on the OMM, both of which can bind actin and induce its polymerization. Loss of either INF2 or Spire1C caused a drastic elongation of the mitochondrial network, accompanied by a reduction in mitochondrial DRP1 (Korobova et al., 2013, Manor et al., 2015). DRP1 and its adaptors MFF and MiD49/51 are also specifically recruited to these mitochondria-ER contact sites, prior to mitochondrial division (Friedman et al., 2011). Finally, trans-Golgi network (TGN) derived vesicles are recruited to ER-induced mitochondrial constriction sites to terminate membranes scission downstream of DRP1 recruitment and activity (Nagashima et al., 2020). Mitochondrial dynamics are also regulated by mitochondria to lysosome tethering. Mitochondrial fission events appear to initiate at these contact sites and are dependent on active lysosome bound RAB7 (Wong et al., 2018, Peng et al., 2020).

The molecular events of IMM fission are less well-defined. Replicating mtDNA has been spatially associated at mitochondria-ER contacts and constrictions, marking future mitochondrial fission sites (Lewis et al., 2016), allowing mtDNA distribution to the two newly generated mitochondria. This new observation describes mtDNA replication as one of the first steps of mitochondrial division, which occurs at the inner membrane. Studies have suggested that IM constriction is $\mathrm{Ca}^{2+}$-dependent (Lee et al., 2018b). Mitochondrial calcium uptake lowers mitochondrial membrane potential leading to the 
activation of OMA1 and the processing of L-OPA1 to S-OPA1 which drives mitochondrial fission in a GTPase dependent fashion (Anand et al., 2014). Finally, MTFP1 (also known as MTP18) is an integral IMM protein proposed to be involved in an early step of mitochondrial division, upstream of DRP1 activity. Indeed, MTP18 loss induces mitochondrial hyper-fusion and a deregulation of DRP1 phosphorylation in a yet unknown mechanism (Tondera et al., 2004, Tondera et al., 2005) while its overexpression causes mitochondrial fragmentation. However, MTP18 lacks catalytic or dynamin-like motifs, making it unlikely to be the executer of inner membrane fission.

\section{Mitochondrial dynamics in quality control}

Mitochondrial fusion has been proposed to preserve cellular integrity (Gomes et al., 2011, Tondera et al., 2009), increase ATP production, and maintain mitochondrial DNA levels (mtDNA) (Chen et al., 2010, Elachouri et al., 2011) (Figure 5). Fusion is believed to benefit mitochondrial function by allowing the spreading of metabolites, proteins and mtDNA throughout the mitochondrial network, allowing functional complementation by diffusion and maximizing bioenergetic capacity. However, experimental evidence supporting a direct role of content mixing as an argument for increased mitochondrial activity is limited (Chen et al., 2010, Nakada et al., 2001). Recent imaging studies demonstrating compartmentalization of ETC function in individual cristae of fused mitochondrial networks therefore calls into question the validity of this theory (Wolf et al., 2019).

Mitochondrial elongation can be observed during stress-induced mitochondrial hyperfusion ( $\mathrm{SiMH})$, a cytoprotective response that occurs in response to exogeneous cellular insults including protein synthesis inhibition, ER stress, and nutrient and oxygen deprivation (Gomes et al., 2011, Khacho et al., 2014, Rambold et al., 2011, Tondera et al., 2009). SiMH is characterized by an elongation of the mitochondrial network resulting from unopposed fusion that requires OPA1 and MFN1 (but not MFN2) and the inner membrane proteolytic scaffold protein SLP2 (Tondera et al., 2009, Wai et al., 2016). At the molecular level, there are clear differences between the essential components for 
OMM and IMM fusion, and those for SiMH: SLP2 is dispensable for mitochondrial morphology under basal conditions, but its depletion prevents the induction of SiMH due to the hyperactivation of OMA1 by a variety of stressors (Wai et al., 2016, Baker et al., 2014). On the other hand, MFN2 and PHB2, while essential for normal mitochondrial morphology, are functionally dispensable for SiMH (Tondera et al., 2009). It is noteworthy that both PHBs and SLP2 act as proteolytic hubs in the IMM: PHBs interact with the m-AAA protease to regulate its proteolytic activities while SLP2 forms a complex with the $i$-AAA protease YME1L and the rhomboid protease PARL, whose substrates are themselves involved in the control of mitophagy, mitochondrial dynamics, stress responses, and programmed cell death. Given the interconnection of these factors and overlapping processes of quality control, it is unclear how to clearly define the individual, biological importance of SiMH. Nevertheless, starvation-induced SiMH has been proposed to be a way of protecting mitochondria from degradation by forming elongated structures that are less accessible for engulfment by mitophagy (Rambold et al., 2011, Gomes et al., 2011). However, more recent work from the Sonenberg and McBride groups demonstrated that mTORC1 inhibition drives mitochondrial elongation caused by the repression of MTFP1 translation. This phenomenoncan be reverted by ectopic expression of MTFP1, without impacting autophagy, indicating that the hyperfusion may not necessarily confer protection against mitophagy (Morita et al., 2017). Mitochondrial dynamics has also been shown to regulate cell death. The fission protein, DRP1 is SUMOylated by MAPL to enhance Mitochondria-ER contacts to recruit activated BAX to promote cytochrome $c$ release, which in turn induces apoptosis (Prudent et al., 2015, Braschi et al., 2009).

Early evidence points towards mitochondrial fission being important for mitophagy (Tanaka et al., 2010, Rambold et al., 2011, Abeliovich et al., 2013, Mao et al., 2013, Kageyama et al., 2014, Ikeda et al., 2015). The Youle lab demonstrated that induction of mitochondrial dysfunction using the uncoupling agent CСCP leads to the fragmentation and elimination of depolarized mitochondria through the PINK1/Parkindependent pathway (Narendra et al., 2008), thus suggesting a link between mitochondrial dynamics and mitophagy. Moreover, it was found that newly derived 
daughter mitochondria with lowered membrane potential are more likely to undergo mitophagy post division (Twig et al., 2008). However, these studies do not distinguish whether fragmentation is required for mitophagy or whether lowered membrane potential alone was sufficient. Initially, mitochondrial fragmentation was thought to be required to generate mitochondria of suitable size for their engulfment in autophagosomes of a restricted size (Baba et al., 1994). In support of this, DRP1 ablation reduced CCCP-induced PINK1/Parkin-dependent mitophagy in INS1 cells (Twig et al., 2008). Furthermore, mitochondria in Opa1 depleted MEFs get degraded during starvation, which has been interpreted as an indication that mitochondrial elongation is protective against mitophagy (Gomes et al., 2011). Although depletion of Opa1 causes defects beyond mitochondrial fusion, including impaired respiration, mtDNA depletion, and cristae dysmorphology, making it challenging to conclude that mitochondrial elongation per se is protective against mitophagy (Giacomello et al., 2020). Comparably, in yeast, deletion of Dnm1 or genes involved in mitochondrial fission such as Fis1, Mdc1, and Caf4 were found to inhibit mitophagy (Kanki and Klionsky, 2008, Mao et al., 2013). However, contradicting reports challenge the notion that mitochondrial fission is a prerequisite for mitophagy. Drp1 impairment by the expression of a dominant-negative Drp1 variant and by depletion of Drp1 did not impair mitophagy in yeast (Mendl et al., 2011, Bernhardt et al., 2015). Furthermore, temporal analysis of both mitochondrial division and mitophagy revealed that division and autophagosome formation occurs independently of DRP1 mediated mitochondrial fission (Yamashita et al., 2016). Surprisingly, while the fission protein DRP1 is not required for mitophagy, it is required to confer selectivity as evidenced by its requirement for the clearance of protein aggregate foci on the mitochondria (Burman et al., 2017). The loss of DRP1 led to the increased distribution of Parkin along the mitochondrial surface away from protein aggregate foci and thereby increased unselective turnover of mitochondria (Burman et al., 2017). Nevertheless, dephosphorylation of the mitophagy receptor FUNDC1 promotes its binding to DRP1 and DRP1-dependent mitochondrial fragmentation (Chen et al., 2016, Wu et al., 2016a), illustrating yet another interconnection between organelle quality control and balanced mitochondrial dynamics. However, the LIR-containing cytosolic portion of FUNDC1 is 
sufficient to induce mitophagy even in the absence of mitochondrial fragmentation (Kuang et al., 2016), indicating that PINK1/Parkin-independent mitophagy can be uncoupled from mitochondrial morphology. Indeed, mitophagy still occurs in the absence of DRP1 in the presence of other mitophagy inducers (hypoxia, iron chelation, proteotoxic stress) (Burman et al., 2017, Yamashita et al., 2016). In such cases, vesiclelike budding of the mitochondria has been proposed to contribute to the generation of small mitochondrial fragments that can be engulfed for mitophagy (Yamashita and Kanki, 2017).

Mitochondrial shape responds to cellular and extracellular cues both in vitro and in vivo, and is known to trigger other cellular quality control mechanisms (Arruda et al., 2014, Gomes et al., 2011, Jacobi et al., 2015, Khacho et al., 2014, Twig et al., 2008). This rapid response is orchestrated by post-translational modifications (PTMs) such as phosphorylation, ubiquitination, SUMOylation, and acetylation of mitochondrial shaping proteins (Sabouny and Shutt, 2020). For example, MFF phosphorylation by (AMP)activated protein kinase (AMPK) promotes the recruitment of DRP1 to mitochondria to induce mitochondrial fission and fragmentation (Toyama et al., 2016). DRP1 is itself a kinase-substrate for PKA (Cribbs and Strack, 2007), Glycogen synthase kinase-3 $\beta$ (GSK3ß) (Loh et al., 2015, Yan et al., 2015), ERK1/2 (Cai et al., 2016, Prieto et al., 2016), and PIM1 (Din et al., 2013) to either promote or inhibit mitochondrial recruitment based upon the phosphorylation site (Sabouny and Shutt, 2020). Interestingly, MFN1 is also phosphorylated by ERK1 to regulate its fusion activity (Pyakurel et al., 2015) while MFN2 contains a PKA phosphorylation site (Zhou et al., 2010) and is also phosphorylated by mitogen-activated protein kinase 8 (MAPK8 also known as JNK) (Leboucher et al., 2012). Additionally, PINK1 phosphorylates MFN2 to promote the recruitment of Parkin to depolarized mitochondria (Chen and Dorn, 2013). Equally important, fusion and fission protein turnover are regulated by the UPS. The E3 Ub ligase Parkin is known to ubiquitinate MFN1 and MFN2 upon mitophagy induction (Gegg et al., 2010, Chen and Dorn, 2013). Furthermore, Parkin-mediated ubiquitination of MFN2 triggers the disassembly of a MFN2-dependent ER-mitochondria tethering complex, which is regulated by p97 (McLelland et al., 2018). Disassembly of this 
complex has been proposed to free up additional OMM proteins for their ubiquitination, including VDAC (McLelland et al., 2018). Thus, ubiquitination not only serves an eat me signal, but is also important for the functional tethering of mitochondria to ER (Basso et al., 2018). MUL1/MAPL is an E3 SUMO/Ubiquitin ligase that acts on OMM proteins including DRP1 (Prudent et al., 2015) and the mitofusin orthologue in flies (Marf), to regulate mitochondrial morphology and mitophagy (Yun et al., 2014). Notably, this pathway functionally overlaps with PINK/Parkin-dependent mitophagy and is induced by metabolic reprogramming (Cilenti et al., 2020). However, both MUL1/MAPL and Parkin are necessary to remove paternal mitochondria from mouse embryos via mitophagy to ensure maternal mitochondrial inheritance (Rojansky et al., 2016), suggesting that multiple Ub pathways might exist in parallel to serve metabolic niches or tissue-specific responses. The mitochondrial Ub ligase MITOL/MARCH5 interacts with and ubiquitinates proteins of the fission-fusion machinery such as DRP1, FIS1 and MFN2 (Nagashima et al., 2014), leading to aggregation of DRP1 at foci. Exemplifying the role of MARCH5 in mitochondrial dynamics, its deletion causes mitochondrial hypertubulation, which is reversed by ectopic expression of DRP1 (Karbowski et al., 2007, Park et al., 2010). MITOL/MARCH also regulates ER tethering to mitochondria by activating MFN2 on mitochondria via K192 ubiquitination (but not ER-bound MFN2) (Sugiura et al., 2013). MFN2 oligomerization depends on ubiquitination, demonstrating a regulatory role of MITOL/MARCH5 in the tuning of mitochondrial fusion and/or membrane contacts while also regulating protein quality control of substrates including mutant SOD1 (Yonashiro et al., 2009).

The physiological importance of mitochondrial shaping proteins is undeniable. Mutations in MFN2 cause the neurodegenerative disease Charcot Marie Tooth Syndrome Type $2 \mathrm{~A}$, characterized by peripheral neuropathy and, in a subset of patients, adipose tissue dysfunction and lipomatosis (Capel et al., 2018, Rocha et al., 2017, Züchner et al., 2004). The majority of patients with dominant mutations in OPA1 manifest isolated optic atrophy, but a subgroup develops a more severe disseminated neurological phenotype as part of a dominant optic atrophy (DOA+) phenotype, including early-onset Behr-like syndrome (Carelli et al., 2015, Delettre et al., 2000). Mutations in DRP1 or its receptors 
can manifest in severe neurological disorders with or without multiple organ involvement (Bartsakoulia et al., 2018, Gerber et al., 2017, Koch et al., 2016, Shamseldin et al., 2012, Waterham et al., 2007). In addition, mutations affecting the mitoproteases that regulate mitochondrial dynamics are also associated with neurodegenerative diseases (Casari et al., 1998, Di Bella et al., 2010, Hartmann et al., 2016). Yet, it has been challenging to ascertain whether imbalanced mitochondrial dynamics resulting from pathogenic mutations in these genes is in fact causal, given the pleiotropic nature of these proteins.

\section{$\underline{\text { Transcriptional responses and mitochondrial proteostasis }}$}

Upon the accumulation of aberrant proteins, mitochondria can respond by inducing nuclear transcriptional changes aimed at decreasing the mitochondrial protein burden. One such process is the UPRmt, which involves signaling cascades that mediate upregulation of nuclear transcribed chaperones and proteases (Figure 6a). UPRmt is best described in C.elegans and appears to be somewhat similar to the human UPRmt (Mottis et al., 2019). In C.elegans, the UPRmt is carried out by the transcription factors ATFS-1 and DVE-1 (homologue to the human SATB2). ATFS-1 contains both a mitochondrial targeting sequence and a nuclear localization signal that forms the basis for its mitochondrial surveillance activity (Haynes et al., 2010). Under normal conditions, ATFS-1 translocates from the cytosol into the mitochondria where it is degraded by the LONP protease (Nargund et al., 2012). However, when mitochondria are rendered import incompetent, newly synthesized ATFS-1 is redirected to the nucleus where it functions as a transcription factor to upregulate the expression of mitochondrial chaperones and metabolic genes (Nargund et al., 2015, Aldridge et al., 2007, Nargund et al., 2012). Similar to ATFS-1, DVE-1 activation is also dependent on its translocation into the nucleus after mitochondrial stress in a process that requires the mitoprotease ClpP and complex formation with the Ub-like protein 5 (Ubl-5) (Haynes et al., 2007). Peptides generated by ClpP are released through the matrix peptide exporter HAF-1 to activate ATFS-1 (Haynes et al., 2010). Interestingly, human SATB2 is also able to interact with Ubl5, suggesting that SATB2 may have conserved functions in relation to 
DVE-1 (Haynes et al., 2007). Indeed, SATB2 was recently shown to be required for UPRmt gene expression upon Antimycin A treatment (Shao et al., 2020), indicating that SATB2 is most likely the functional equivalent of DVE-1 in mammals. These factors are regulated by SUMOylation: the yeast Ub-like-specific protease 4 (ULP-4) removes inhibitory SUMO-tags from ATFS-1 (at K326) and DVE-1 (at K327) upon mitochondrial stress to stabilize and activate ATFS-1, and at the same time promote the nuclear translocation of DVE-1 in order to activate mitochondrial protective genes (Gao et al., 2019). SATB2 can also be SUMOylated to alter its subnuclear localization (Dobreva et al., 2003).

In mammals, the UPRmt is a segment of the integrated stress response pathway (ISR). The ISR is a signaling pathway that leads to selective inhibition of a set of genes, while at the same time favoring the expression of stress response genes leading to global gene, protein and metabolic reprogramming (Figure 6b). The ISR is initiated by the eukaryotic initiation factor (elF2 $\alpha$ ) kinases, consisting of heme-regulated inhibitor (HRI), PKR-like ER kinase (PERK), general control non-depressible 2 (GCN2) and protein kinase $R(P K R)$, which are activated upon cellular stress, specific for each of the kinases, to phosphorylate a serine residue on elF2 $\alpha$ (Costa-Mattioli and Walter, 2020). Phosphorylated-elF2 $\alpha$ results in a global decrease in translation to decrease protein burden while simultaneously upregulating the expression of genes that will contribute to reestablish homeostasis. Among the genes upregulated by phosphorylated-elF2 $\alpha$ are genes of the activating transcription factor (ATF) family. ATFs are bZIP transcription factors that are capable of forming homo- and/or hetero-dimers with other bZIP transcription factors and have been implicated in a variety of cellular stress responses. While the ATF family consists of 8 different members, ATF4 and ATF5 are the functional homologs of ATFS-1 in humans (Fiorese et al., 2016, Quirós et al., 2017). ATF5 induces a similar transcriptional response compared to ATFS-1, and was remarkably able to rescue UPRmt signaling in C.elegans lacking atfs-1 (Fiorese et al., 2016), indicating that the UPRmt is conserved between C.elegans and mammals. Mitochondrial stress is relayed through OMA1-dependent cleavage of the inner mitochondrial protein DAP3-binding cell death enhancer 1 (DELE1) (Guo et al., 2020, 
Fessler et al., 2020) and DELE1 cleavage leads to its export to the cytosol where it interacts with HRI to phosphorylate elF2 $\alpha$, leading to activation of ATF4 (Guo et al., 2020, Fessler et al., 2020). Similarly, ATF5 is itself transcriptionally upregulated in response to elF2 $\alpha$ phosphorylation in response to proteasome inhibition and mitochondrial dysfunction induced by arsenite treatment (Zhou et al., 2008), and this is dependent on the upstream binding of ATF4 to the ATF5 promoter (Teske et al., 2013). Interestingly, the expression of the transcription factor ATF3 of the ATF family is also induced during mammalian UPRmt (Münch and Harper, 2016), suggesting that other members of the ATF family are also involved in UPRmt.

In addition to the UPRmt, mitochondria-to-nucleus signaling also occurs through the SiRT3-FOXO3A axis. Specifically, misfolded protein accumulation leads to stabilization of the mitochondrial deacetylase SiRT3 which in turn induces mitophagy and antioxidant defense mechanism through the deacetylation and activation of magnesium superoxide dimutase (MnSOD) and the transcription factor Forkhead box O3 (FOXO3A) (Papa and Germain, 2014). FOXO3A deacetylation by SiRT3 stimulates its nuclear translocation and FOXO3A dependent transcription of the antioxidant encoding genes like MnSOD and Catalase in order to reduce oxidative stress in the mitochondria (Sundaresan et al., 2009).

Peroxisomal proliferator-activated receptor Gamma Coactivator 1 alpha (PGC1 $\alpha$ ) is the master regulator of mitochondrial biogenesis that regulates metabolic rewiring in the face of different environmental cues and metabolic demand (reviewed elsewhere (RiusPérez et al., 2020)). Parkin is able to induce activation of PGC1a through ubiquitination of Parkin interacting substrate (PARIS), a transcriptional repressor of PGC1a, with K48linkages, leading to its degradation by the proteasome. Thus, upon activation by mitochondrial damage, Parkin activation leads to UPS-mediated degradation of PARIS which relieves the repression of PGC1a expression, and stimulates mitochondrial biogenesis to restore normal mitochondrial function (Shin et al., 2011). In breast cancer (BCa) cells, the accumulation of proteins in the IMS leads to a novel pathway of UPRmt activation that involves the Estrogen receptor alpha $(E R \alpha)$. In short, proteotoxic stress in the IMS leads to a signaling cascade involving reactive oxygen species (ROS) and AKT, 
which results in phosphorylation and activation of ERa. This facilitates its ligand-free translocation into the nucleus to upregulate the transcription of the mitochondrial proteases? HTRA2 and NRF1 (Papa and Germain, 2011), possibly allowing BCa cells to overcome excessive mitochondrial damage, which in turn, increases cell survival and confers the ability to persist through estrogen depleted conditions.

\section{Mitochondrial transfer}

A relatively new and unexplored concept put forth is the secretion of mitochondria from cells. Interestingly, proteins of mitochondrial origin have been observed in the proteome of the exosome (Mathivanan et al., 2012). The biological function of these extracellular mitochondria is not fully explored, nor do we know how mitochondria are loaded into extracellular vesicles. While extracellular mitochondria have been implicated in inflammatory signaling (Puhm et al., 2019, Boudreau et al., 2014), recent reports have proposed that expulsion of mitochondria from cells function as a novel quality control mechanism for removal of damaged mitochondria. Supporting this idea, mitochondria in C.elegans have been reported to extrudefrom the cell in $4 \mu \mathrm{m}$ large vesicles called exophers upon the induction of proteotoxic stress, caused by hampering chaperone activity, inhibition of the proteasome or knockdown of autophagy proteins (Melentijevic et al., 2017). Recent reports also describe the release of exophers containing defective mitochondria from mammalian cardiomyocytes that are captured by cardiac-resident macrophages for degradation (Nicolás-Ávila et al., 2020). In humans, cell-free respiratory competent mitochondria have been observed in the blood (Al Amir Dache et al., 2020), however the biological significance underlying their release is not well understood. Extracellular vesicles secreted from melanoma-tissue cells were found to be enriched in mitochondrial membrane proteins (Jang et al., 2019). Additionally, small extracellular vesicles from PD patients contained lower amounts of the tetraspanins, CD9 and CD63, and the mitochondrial proteins ATP5A, NDUFS3, and SDHB (Picca et al., 2020) suggesting that mitochondria are differently secreted in disease states. This led to speculations that unique mitochondrial protein signatures in extracellular vesicles may provide diagnostic or prognostic value as biomarkers for diseases like PD and 
cancer. Mitochondrial release to the extracellular microenvironment might contribute to the debilitated mitochondrial function often seen in diseases. Indeed, mitochondria transfer through tunneling nanotubes (TNTs) promoted survival and invasiveness in prostate cancer (Wang and Gerdes, 2015) and bladder cancer cells (Lu et al., 2017). TNTs are nanotubular structures of around $50-200 \mathrm{~nm}$ in diameter that are able to mediate the transfer of cytosolic material (including organelles) between cells (Rustom et al., 2004). TNT mediated mitochondria transfer appears to promote mesenchymal stem cell (MSC) repair after rotenone-induced mitochondrial dysfunction (Ahmad et al., 2014). MSCs were also able to mediate mitochondria transfer through nanotubes to decrease apoptosis and enhance the aerobic capacity in HUVEC cells after damage caused by simulated ischemia-reperfusion injury (Liu et al., 2014). Ischemia also led to the transfer of astrocytic mitochondria into neurons and was correlated with increased neuroprotection in mice (Hayakawa et al., 2016). Thus, it appears that receiving external mitochondria may be beneficial for neighboring cells. Interestingly, mitochondria from retinal ganglion cells were found to be associated to lysosomes of adjoining glial cells where they are degraded (Davis et al., 2014). This raises the question if cells necessarily degrade their own mitochondria or if neighboring cells can take over this task. This will have significance for diseases that are often characterized by mitochondrial dysfunction and are dependent on autophagy of neighboring cells such as cancer (Katheder et al., 2017). Overall, the amount of mitochondria or mitochondrialderived cargo circulating or transferred to other cells and tissues in most of these studies represents a fraction of the mitochondrial content of acceptor cells and tissues, and thus makes it unlikely that incoming mitochondria provide significant bioenergetic benefits and may rather, if true, reflect signaling function(s) of the organelle (Chandel, 2015).

\section{Concluding remarks and perspectives}

As we continue to push the boundary of our understanding of the various mitochondrial quality control mechanisms, it is important to keep in mind the pleiotropy of the different players. Core proteins in a given quality control mechanism are also involved in the 
other quality control pathways and thus the true overall picture of mitochondrial quality control resembles a tangled web rather than individual, independent pathways. Illustrating this, DRP1, while best known for its role in mitochondrial fission (Smirnova et al., 2001), also influences different independent and downstream processes such as calcium homeostasis (Favaro et al., 2019), DNA damage response (Qian et al., 2012), OXPHOS (Bras et al., 2007), apoptosis (Frank et al., 2001) and mitophagy (Kageyama et al., 2014) as well as peroxisomal fission (Waterham et al., 2007). Another example, Parkin, is a protein well studied for its role in mitophagy, but is also involved in proteasome-dependent protein degradation (Yoshii et al., 2011), mitochondrial fission (Buhlman et al., 2014), regulation of mitochondrial mRNA translation and localization (Gehrke et al., 2015), MDV formation (McLelland et al., 2014) and apoptosis (Carroll et al., 2014). Thus, it is problematic to make broad conclusions based on the outcome of manipulations of a single member of a pathway that is also involved in other regulatory processes. As such, it is crucial to understand how different quality control mechanisms are interconnected, if there is a scale, threshold or type of mitochondrial damage that elicits the different responses, if these processes occur simultaneously or in hierarchical sequence, and if they are dependent or independent of each other. Investigation into the spatiotemporal relationship between the different mechanisms may reveal dependencies and inter-regulation of the different pathways. Despite the recent advances in our understanding of mitochondrial quality control, much remains to be discovered, especially with regards to the relationship between different quality control mechanisms and how they are regulated under various pathophysiological conditions.

\section{Acknowledgements}

This work was supported by the Research Council of Norway through its Center of Excellence funding scheme (Project: 262652) and FRIPRO grants (Project: 221831) and by a European Research Council (ERC) Starting Grant to T.W. (No. 714472 Acronym "Mitomorphosis").

Figures were generated using Biorender.com 


\section{$\underline{\text { References }}$}

ABELIOVICH, H., ZAREI, M., RIGBOLT, K. T. G., YOULE, R. J. \& DENGJEL, J. 2013. Involvement of mitochondrial dynamics in the segregation of mitochondrial matrix proteins during stationary phase mitophagy. Nature Communications, 4, 2789.

ABUAITA, B. H., SCHULTZ, T. L. \& O'RIORDAN, M. X. 2018. Mitochondria-Derived Vesicles Deliver Antimicrobial Reactive Oxygen Species to Control Phagosome-Localized Staphylococcus aureus. Cell Host Microbe, 24, 625-636.e5.

ACIN-PEREZ, R., LECHUGA-VIECO, A. V., DEL MAR MUÑOZ, M., NIETO-ARELLANO, R., TORROJA, C., SÁNCHEZ-CABO, F., JIMÉNEZ, C., GONZÁLEZ-GUERRA, A., CARRASCOSO, I., BENINCÁ, C., QUIROS, P. M., LÓPEZ-OTÍN, C., CASTELLANO, J. M., RUÍZ-CABELLO, J., JIMÉNEZ-BORREGUERO, L. J. \& ENRÍQUEZ, J. A. 2018. Ablation of the stress protease OMA1 protects against heart failure in mice. Sci Transl Med, 10.

AHMAD, T., MUKHERJEE, S., PATTNAIK, B., KUMAR, M., SINGH, S., KUMAR, M., REHMAN, R., TIWARI, B. K., JHA, K. A., BARHANPURKAR, A. P., WANI, M. R., ROY, S. S., MABALIRAJAN, U., GHOSH, B. \& AGRAWAL, A. 2014. Miro1 regulates intercellular mitochondrial transport \& enhances mesenchymal stem cell rescue efficacy. The EMBO Journal, 33, 994-1010.

AL AMIR DACHE, Z., OTANDAULT, A., TANOS, R., PASTOR, B., MEDDEB, R., SANCHEZ, C., ARENA, G., LASORSA, L., BENNETT, A., GRANGE, T., EL MESSAOUDI, S., MAZARD, T., PREVOSTEL, C. \& THIERRY, A. R. 2020. Blood contains circulating cell-free respiratory competent mitochondria. The FASEB Journal, 34, 3616-3630.

ALDRIDGE, J. E., HORIBE, T. \& HOOGENRAAD, N. J. 2007. Discovery of genes activated by the mitochondrial unfolded protein response (mtUPR) and cognate promoter elements. PLoS One, 2, e874.

ALLEN, G. F. G., TOTH, R., JAMES, J. \& GANLEY, I. G. 2013. Loss of iron triggers PINK1/Parkin-independent mitophagy. EMBO reports, 14, 1127-1135.

ANAND, R., WAI, T., BAKER, M. J., KLADT, N., SCHAUSS, A. C., RUGARLI, E. \& LANGER, T. 2014. The i-AAA protease YME1L and OMA1 cleave OPA1 to balance mitochondrial fusion and fission. Journal of Cell Biology, 204, 919-929.

ARRUDA, A. P., PERS, B. M., PARLAKGÜL, G., GÜNEY, E., INOUYE, K. \& HOTAMISLIGIL, G. S. 2014. Chronic enrichment of hepatic endoplasmic reticulum-mitochondria contact leads to mitochondrial dysfunction in obesity. Nature Medicine, 20, 1427-1435.

BABA, M., TAKESHIGE, K., BABA, N. \& OHSUMI, Y. 1994. Ultrastructural analysis of the autophagic process in yeast: detection of autophagosomes and their characterization. Journal of Cell Biology, 124, 903-913.

BAKER, M. J., LAMPE, P. A., STOJANOVSKI, D., KORWITZ, A., ANAND, R., TATSUTA, T. \& LANGER, T. 2014. Stress-induced OMA1 activation and autocatalytic turnover regulate OPA1-dependent mitochondrial dynamics. The EMBO Journal, 33, 578-593.

BARTSAKOULIA, M., PYLE, A., TRONCOSO-CHANDÍA, D., VIAL-BRIZZI, J., PAZ-FIBLAS, M. V., DUFF, J., GRIFFIN, H., BOCZONADI, V., LOCHMÜLLER, H., KLEINLE, S., CHINNERY, P. F., GRÜNERT, S., KIRSCHNER, J., EISNER, V. \& HORVATH, R. 2018. A novel mechanism causing imbalance of mitochondrial fusion and fission in human myopathies. Human Molecular Genetics, 27, 11861195. 
BASSO, V., MARCHESAN, E., PEGGION, C., CHAKRABORTY, J., VON STOCKUM, S., GIACOMELLO, M., OTTOLINI, D., DEBATTISTI, V., CAICCI, F., TASCA, E., PEGORARO, V., ANGELINI, C., ANTONINI, A., BERTOLI, A., BRINI, M. \& ZIVIANI, E. 2018. Regulation of ER-mitochondria contacts by Parkin via Mfn2. Pharmacological Research, 138, 43-56.

BELLOT, G., GARCIA-MEDINA, R., GOUNON, P., CHICHE, J., ROUX, D., POUYSSÉGUR, J. \& MAZURE, N. M. 2009. Hypoxia-induced autophagy is mediated through hypoxia-inducible factor induction of BNIP3 and BNIP3L via their BH3 domains. Molecular and Cellular Biology, 29, 2570-81.

BENNETT, E. J., BENCE, N. F., JAYAKUMAR, R. \& KOPITO, R. R. 2005. Global impairment of the ubiquitinproteasome system by nuclear or cytoplasmic protein aggregates precedes inclusion body formation. Molecular Cell, 17, 351-65.

BERNARDINI, J. P., LAZAROU, M. \& DEWSON, G. 2017. Parkin and mitophagy in cancer. Oncogene, 36, 1315-1327.

BERNHARDT, D., MÜLLER, M., REICHERT, A. S. \& OSIEWACZ, H. D. 2015. Simultaneous impairment of mitochondrial fission and fusion reduces mitophagy and shortens replicative lifespan. Scientific Reports, 5, 7885.

BHUJABAL, Z., BIRGISDOTTIR Å, B., SJØTTEM, E., BRENNE, H. B., ØVERVATN, A., HABISOV, S., KIRKIN, V., LAMARK, T. \& JOHANSEN, T. 2017. FKBP8 recruits LC3A to mediate Parkin-independent mitophagy. EMBO reports, 18, 947-961.

BOHOVYCH, I., DONALDSON, G., CHRISTIANSON, S., ZAHAYKO, N. \& KHALIMONCHUK, O. 2014. Stresstriggered activation of the metalloprotease Oma1 involves its C-terminal region and is important for mitochondrial stress protection in yeast. Journal of Biological Chemistry, 289, 13259-72.

BOTA, D. A. \& DAVIES, K. J. A. 2016. Mitochondrial Lon protease in human disease and aging: Including an etiologic classification of Lon-related diseases and disorders. Free Radical Biology and Medicine, 100, 188-198.

BOUdREAU, L. H., DUCHEZ, A.-C., CLOUTIER, N., SOULET, D., MARTIN, N., BOLLINGER, J., PARÉ, A., ROUSSEAU, M., NAIKA, G. S., LÉVESQUE, T., LAFLAMME, C., MARCOUX, G., LAMBEAU, G., FARNDALE, R. W., POULIOT, M., HAMZEH-COGNASSE, H., COGNASSE, F., GARRAUD, O., NIGROVIC, P. A., GUDERLEY, H., LACROIX, S., THIBAULT, L., SEMPLE, J. W., GELB, M. H. \& BOILARD, E. 2014. Platelets release mitochondria serving as substrate for bactericidal group IIAsecreted phospholipase A2 to promote inflammation. Blood, 124, 2173-2183.

BRAGOSZEWSKI, P., WASILEWSKI, M., SAKOWSKA, P., GORNICKA, A., BÖTTINGER, L., QIU, J., WIEDEMANN, N. \& CHACINSKA, A. 2015. Retro-translocation of mitochondrial intermembrane space proteins. Proceedings of the National Academy of Sciences, 112, 7713-8.

BRANDMAN, O., STEWART-ORNSTEIN, J., WONG, D., LARSON, A., WILLIAMS, CHRISTOPHER C., LI, G.-W., ZHOU, S., KING, D., SHEN, PETER S., WEIBEZAHN, J., DUNN, JOSHUA G., ROUSKIN, S., INADA, T., FROST, A. \& WEISSMAN, JONATHAN S. 2012. A Ribosome-Bound Quality Control Complex Triggers Degradation of Nascent Peptides and Signals Translation Stress. Cell, 151, 1042-1054.

BRAS, M., YUSTE, V. J., ROUÉ, G., BARBIER, S., SANCHO, P., VIRELY, C., RUBIO, M., BAUDET, S., ESQUERDA, J. E., MERLE-BÉRAL, H., SARFATI, M. \& SUSIN, S. A. 2007. Drp1 mediates caspaseindependent type III cell death in normal and leukemic cells. Molecular and Cellular Biology, 27, 7073-88.

BRASCHI, E., GOYON, V., ZUNINO, R., MOHANTY, A., XU, L. \& MCBRIDE, H. M. 2010. Vps35 mediates vesicle transport between the mitochondria and peroxisomes. Current Biology, 20, 1310-5.

BRASCHI, E., ZUNINO, R. \& MCBRIDE, H. M. 2009. MAPL is a new mitochondrial SUMO E3 ligase that regulates mitochondrial fission. EMBO Rep, 10, 748-54.

BROSS, P., ANDRESEN, B. S., KNUDSEN, I., KRUSE, T. A. \& GREGERSEN, N. 1995. Human ClpP protease: cDNA sequence, tissue-specific expression and chromosomal assignment of the gene. FEBS Lett, $377,249-52$. 
BUHLMAN, L., DAMIANO, M., BERTOLIN, G., FERRANDO-MIGUEL, R., LOMBÈS, A., BRICE, A. \& CORTI, O. 2014. Functional interplay between Parkin and Drp1 in mitochondrial fission and clearance. Biochimica et Biophysica Acta (BBA) - Molecular Cell Research, 1843, 2012-2026.

BURMAN, J. L., PICKLES, S., WANG, C., SEKINE, S., VARGAS, J. N. S., ZHANG, Z., YOULE, A. M., NEZICH, C. L., WU, X., HAMMER, J. A. \& YOULE, R. J. 2017. Mitochondrial fission facilitates the selective mitophagy of protein aggregates. Journal of Cell Biology, 216, 3231-3247.

BYKOV, Y. S., RAPAPORT, D., HERRMANN, J. M. \& SCHULDINER, M. 2020. Cytosolic Events in the Biogenesis of Mitochondrial Proteins. Trends in Biochemical Sciences, 45, 650-667.

CADETE, V. J. J., DESCHÊNES, S., CUILLERIER, A., BRISEBOIS, F., SUGIURA, A., VINCENT, A., TURNBULL, D., PICARD, M., MCBRIDE, H. M. \& BURELLE, Y. 2016. Formation of mitochondrial-derived vesicles is an active and physiologically relevant mitochondrial quality control process in the cardiac system. The Journal of physiology, 594, 5343-5362.

CAI, J., WANG, J., HUANG, Y., WU, H., XIA, T., XIAO, J., CHEN, X., LI, H., QIU, Y., WANG, Y., WANG, T., XIA, H., ZHANG, Q. \& XIANG, A. P. 2016. ERK/Drp1-dependent mitochondrial fission is involved in the MSC-induced drug resistance of T-cell acute lymphoblastic leukemia cells. Cell death \& disease, 7, e2459-e2459.

CAPEL, E., VATIER, C., CERVERA, P., STOJKOVIC, T., DISSE, E., COTTEREAU, A. S., AUCLAIR, M., VERPONT, M. C., MOSBAH, H., GOURDY, P., BARRAUD, S., MIQUEL, A., ZÜCHNER, S., BONNEFOND, A., FROGUEL, P., CHRISTIN-MAITRE, S., DELEMER, B., FÈVE, B., LAVILLE, M., ROBERT, J., TENENBAUM, F., LASCOLS, O., VIGOUROUX, C. \& JÉRU, I. 2018. MFN2-associated lipomatosis: Clinical spectrum and impact on adipose tissue. Journal of Clinical Lipidology, 12, 1420-1435.

CARELLI, V., SABATELLI, M., CARROZZO, R., RIZZA, T., SCHIMPF, S., WISSINGER, B., ZANNA, C., RUGOLO, M., LA MORGIA, C., CAPORALI, L., CARBONELLI, M., BARBONI, P., TONON, C., LODI, R. \& BERTINI, E. 2015. 'Behr syndrome' with OPA1 compound heterozygote mutations. Brain, 138, e321-e321.

CARROLL, RICHARD G., HOLLVILLE, E. \& MARTIN, SEAMUS J. 2014. Parkin Sensitizes toward Apoptosis Induced by Mitochondrial Depolarization through Promoting Degradation of Mcl-1. Cell Reports, 9, 1538-1553.

CASARI, G., DE FUSCO, M., CIARMATORI, S., ZEVIANI, M., MORA, M., FERNANDEZ, P., DE MICHELE, G., FILLA, A., COCOZZA, S., MARCONI, R., DÜRR, A., FONTAINE, B. \& BALLABIO, A. 1998. Spastic paraplegia and OXPHOS impairment caused by mutations in paraplegin, a nuclear-encoded mitochondrial metalloprotease. Cell, 93, 973-83.

CHANDEL, N. S. 2015. Evolution of Mitochondria as Signaling Organelles. Cell Metabolism, 22, 204-6.

CHATZISPYROU, I. A., ALDERS, M., GUERRERO-CASTILLO, S., ZAPATA PEREZ, R., HAAGMANS, M. A., MOUCHIROUD, L., KOSTER, J., OFMAN, R., BAAS, F., WATERHAM, H. R., SPELBRINK, J. N., AUWERX, J., MANNENS, M. M., HOUTKOOPER, R. H. \& PLOMP, A. S. 2017. A homozygous missense mutation in ERAL1, encoding a mitochondrial rRNA chaperone, causes Perrault syndrome. Human Molecular Genetics, 26, 2541-2550.

CHEN, G., HAN, Z., FENG, D., CHEN, Y., CHEN, L., WU, H., HUANG, L., ZHOU, C., CAI, X., FU, C., DUAN, L., WANG, X., LIU, L., LIU, X., SHEN, Y., ZHU, Y. \& CHEN, Q. 2014. A regulatory signaling loop comprising the PGAM5 phosphatase and CK2 controls receptor-mediated mitophagy. Molecular Cell, 54, 362-77.

CHEN, H., DETMER, S. A., EWALD, A. J., GRIFFIN, E. E., FRASER, S. E. \& CHAN, D. C. 2003. Mitofusins Mfn1 and $\mathrm{Mfn} 2$ coordinately regulate mitochondrial fusion and are essential for embryonic development. Journal of Cell Biology, 160, 189-200.

CHEN, H., VERMULST, M., WANG, Y. E., CHOMYN, A., PROLLA, T. A., MCCAFFERY, J. M. \& CHAN, D. C. 2010. Mitochondrial fusion is required for mtDNA stability in skeletal muscle and tolerance of mtDNA mutations. Cell, 141, 280-289. 
CHEN, M., CHEN, Z., WANG, Y., TAN, Z., ZHU, C., LI, Y., HAN, Z., CHEN, L., GAO, R., LIU, L. \& CHEN, Q. 2016. Mitophagy receptor FUNDC1 regulates mitochondrial dynamics and mitophagy. Autophagy, 12, 689-702.

CHEN, Y. \& DORN, G. W., 2ND 2013. PINK1-phosphorylated mitofusin 2 is a Parkin receptor for culling damaged mitochondria. Science, 340, 471-475.

CHU, C. T., JI, J., DAGDA, R. K., JIANG, J. F., TYURINA, Y. Y., KAPRALOV, A. A., TYURIN, V. A., YANAMALA, N., SHRIVASTAVA, I. H., MOHAMMADYANI, D., QIANG WANG, K. Z., ZHU, J., KLEINSEETHARAMAN, J., BALASUBRAMANIAN, K., AMOSCATO, A. A., BORISENKO, G., HUANG, Z., GUSDON, A. M., CHEIKHI, A., STEER, E. K., WANG, R., BATY, C., WATKINS, S., BAHAR, I., BAYIR, H. \& KAGAN, V. E. 2013. Cardiolipin externalization to the outer mitochondrial membrane acts as an elimination signal for mitophagy in neuronal cells. Nature Cell Biology, 15, 1197-1205.

CILENTI, L., DI GREGORIO, J., AMBIVERO, C. T., ANDL, T., LIAO, R. \& ZERVOS, A. S. 2020. Mitochondrial MUL1 E3 ubiquitin ligase regulates Hypoxia Inducible Factor (HIF-1 $\alpha$ ) and metabolic reprogramming by modulating the UBXN7 cofactor protein. Scientific Reports, 10, 1609.

CIPOLAT, S., MARTINS DE BRITO, O., DAL ZILIO, B. \& SCORRANO, L. 2004. OPA1 requires mitofusin 1 to promote mitochondrial fusion. Proceedings of the National Academy of Sciences, 101, 15927-32.

CIPOLAT, S., RUDKA, T., HARTMANN, D., COSTA, V., SERNEELS, L., CRAESSAERTS, K., METZGER, K., FREZZA, C., ANNAERT, W., D'ADAMIO, L., DERKS, C., DEJAEGERE, T., PELLEGRINI, L., D'HOOGE, R., SCORRANO, L. \& DE STROOPER, B. 2006. Mitochondrial rhomboid PARL regulates cytochrome $C$ release during apoptosis via OPA1-dependent cristae remodeling. Cell, 126, 163-75.

COHEN, M. M., LEBOUCHER, G. P., LIVNAT-LEVANON, N., GLICKMAN, M. H. \& WEISSMAN, A. M. 2008. Ubiquitin-proteasome-dependent degradation of a mitofusin, a critical regulator of mitochondrial fusion. Molecular Biology of the Cell, 19, 2457-64.

COSTA-MATTIOLI, M. \& WALTER, P. 2020. The integrated stress response: From mechanism to disease. Science, 368, eaat5314.

CRIBBS, J. T. \& STRACK, S. 2007. Reversible phosphorylation of Drp1 by cyclic AMP-dependent protein kinase and calcineurin regulates mitochondrial fission and cell death. EMBO reports, 8, 939-944.

DAVIS, C.-H. O., KIM, K.-Y., BUSHONG, E. A., MILLS, E. A., BOASSA, D., SHIH, T., KINEBUCHI, M., PHAN, S., ZHOU, Y., BIHLMEYER, N. A., NGUYEN, J. V., JIN, Y., ELLISMAN, M. H. \& MARSH-ARMSTRONG, N. 2014. Transcellular degradation of axonal mitochondria. Proceedings of the National Academy of Sciences, 111, 9633-9638.

DE BRITO, O. M. \& SCORRANO, L. 2008. Mitofusin 2 tethers endoplasmic reticulum to mitochondria. Nature, 456, 605-10.

DEAS, E., PLUN-FAVREAU, H., GANDHI, S., DESMOND, H., KJAER, S., LOH, S. H. Y., RENTON, A. E. M., HARVEY, R. J., WHITWORTH, A. J., MARTINS, L. M., ABRAMOV, A. Y. \& WOOD, N. W. 2010. PINK1 cleavage at position A103 by the mitochondrial protease PARL. Human Molecular Genetics, 20, 867-879.

DEFENOUILLÈRE, Q., YAO, Y., MOUAIKEL, J., NAMANE, A., GALOPIER, A., DECOURTY, L., DOYEN, A., MALABAT, C., SAVEANU, C., JACQUIER, A. \& FROMONT-RACINE, M. 2013. Cdc48-associated complex bound to $60 \mathrm{~S}$ particles is required for the clearance of aberrant translation products. Proceedings of the National Academy of Sciences, 110, 5046-5051.

DELETTRE, C., LENAERS, G., GRIFFOIN, J. M., GIGAREL, N., LORENZO, C., BELENGUER, P., PELLOQUIN, L., GROSGEORGE, J., TURC-CAREL, C., PERRET, E., ASTARIE-DEQUEKER, C., LASQUELLEC, L., ARNAUD, B., DUCOMMUN, B., KAPLAN, J. \& HAMEL, C. P. 2000. Nuclear gene OPA1, encoding a mitochondrial dynamin-related protein, is mutated in dominant optic atrophy. Nature Genetics, 26, 207-10.

DEOL, K. K., LORENZ, S. \& STRIETER, E. R. 2019. Enzymatic Logic of Ubiquitin Chain Assembly. Frontiers in Physiology, 10. 
DESHWAL, S., FIEDLER, K. U. \& LANGER, T. 2020. Mitochondrial Proteases: Multifaceted Regulators of Mitochondrial Plasticity. Annual Review of Biochemistry, 89, 501-528.

DI BELLA, D., LAZZARO, F., BRUSCO, A., PLUMARI, M., BATTAGLIA, G., PASTORE, A., FINARDI, A., CAGNOLI, C., TEMPIA, F., FRONTALI, M., VENEZIANO, L., SACCO, T., BODA, E., BRUSSINO, A., BONN, F., CASTELLOTTI, B., BARATTA, S., MARIOTTI, C., GELLERA, C., FRACASSO, V., MAGRI, S., LANGER, T., PLEVANI, P., DI DONATO, S., MUZI-FALCONI, M. \& TARONI, F. 2010. Mutations in the mitochondrial protease gene AFG3L2 cause dominant hereditary ataxia SCA28. Nature Genetics, 42, 313-21.

DIKIC, I. \& ELAZAR, Z. 2018. Mechanism and medical implications of mammalian autophagy. Nature Reviews Molecular Cell Biology, 19, 349-364.

DIN, S., MASON, M., VÖLKERS, M., JOHNSON, B., COTTAGE, C. T., WANG, Z., JOYO, A. Y., QUIJADA, P., ERHARDT, P., MAGNUSON, N. S., KONSTANDIN, M. H. \& SUSSMAN, M. A. 2013. Pim-1 preserves mitochondrial morphology by inhibiting dynamin-related protein 1 translocation. Proceedings of the National Academy of Sciences, 110, 5969-5974.

DIWAN, A., KOESTERS, A. G., ODLEY, A. M., PUSHKARAN, S., BAINES, C. P., SPIKE, B. T., DARIA, D., JEGGA, A. G., GEIGER, H., ARONOW, B. J., MOLKENTIN, J. D., MACLEOD, K. F., KALFA, T. A. \& DORN, G. W., 2ND 2007. Unrestrained erythroblast development in Nix-/- mice reveals a mechanism for apoptotic modulation of erythropoiesis. Proceedings of the National Academy of Sciences, 104, 6794-6799.

DOBREVA, G., DAMBACHER, J. \& GROSSCHEDL, R. 2003. SUMO modification of a novel MAR-binding protein, SATB2, modulates immunoglobulin mu gene expression. Genes \& development, 17, 3048-3061.

DRAKE, J. C., LAKER, R. C., WILSON, R. J., ZHANG, M. \& YAN, Z. 2019. Exercise-induced mitophagy in skeletal muscle occurs in the absence of stabilization of Pink1 on mitochondria. Cell cycle, 18, 16.

EHSES, S., RASCHKE, I., MANCUSO, G., BERNACCHIA, A., GEIMER, S., TONDERA, D., MARTINOU, J. C., WESTERMANN, B., RUGARLI, E. I. \& LANGER, T. 2009. Regulation of OPA1 processing and mitochondrial fusion by m-AAA protease isoenzymes and OMA1. Journal of Cell Biology, 187, 1023-36.

ELACHOURI, G., VIDONI, S., ZANNA, C., PATTYN, A., BOUKHADDAOUI, H., GAGET, K., YU-WAI-MAN, P., GASPARRE, G., SARZI, E., DELETTRE, C., OLICHON, A., LOISEAU, D., REYNIER, P., CHINNERY, P. F., ROTIG, A., CARELLI, V., HAMEL, C. P., RUGOLO, M. \& LENAERS, G. 2011. OPA1 links human mitochondrial genome maintenance to mtDNA replication and distribution. Genome research, $21,12-20$.

EVANS, C. S. \& HOLZBAUR, E. L. F. 2020. Degradation of engulfed mitochondria is rate-limiting in Optineurin-mediated mitophagy in neurons. elife, 9, e50260.

FAELBER, K., DIETRICH, L., NOEL, J. K., WOLLWEBER, F., PFITZNER, A.-K., MÜHLEIP, A., SÁNCHEZ, R., KUDRYASHEV, M., CHIARUTTINI, N., LILIE, H., SCHLEGEL, J., ROSENBAUM, E., HESSENBERGER, M., MATTHAEUS, C., KUNZ, S., VON DER MALSBURG, A., NOÉ, F., ROUX, A., VAN DER LAAN, M., KÜHLBRANDT, W. \& DAUMKE, O. 2019. Structure and assembly of the mitochondrial membrane remodelling GTPase Mgm1. Nature, 571, 429-433.

FAVARO, G., ROMANELLO, V., VARANITA, T., ANDREA DESBATS, M., MORBIDONI, V., TEZZE, C., ALBIERO, M., CANATO, M., GHERARDI, G., DE STEFANI, D., MAMMUCARI, C., BLAAUW, B., BONCOMPAGNI, S., PROTASI, F., REGGIANI, C., SCORRANO, L., SALVIATI, L. \& SANDRI, M. 2019. DRP1-mediated mitochondrial shape controls calcium homeostasis and muscle mass. Nature Communications, 10, 2576. 
FESSLER, E., ECKL, E.-M., SCHMITT, S., MANCILLA, I. A., MEYER-BENDER, M. F., HANF, M., PHILIPPOUMASSIER, J., KREBS, S., ZISCHKA, H. \& JAE, L. T. 2020. A pathway coordinated by DELE1 relays mitochondrial stress to the cytosol. Nature, 579, 433-437.

FIORESE, C. J., SCHULZ, A. M., LIN, Y. F., ROSIN, N., PELLEGRINO, M. W. \& HAYNES, C. M. 2016. The Transcription Factor ATF5 Mediates a Mammalian Mitochondrial UPR. Current Biology, 26, 20372043.

FRANK, S., GAUME, B., BERGMANN-LEITNER, E. S., LEITNER, W. W., ROBERT, E. G., CATEZ, F., SMITH, C. L. \& YOULE, R. J. 2001. The Role of Dynamin-Related Protein 1, a Mediator of Mitochondrial Fission, in Apoptosis. Developmental Cell, 1, 515-525.

FREZZA, C., CIPOLAT, S., MARTINS DE BRITO, O., MICARONI, M., BEZNOUSSENKO, G. V., RUDKA, T., BARTOLI, D., POLISHUCK, R. S., DANIAL, N. N., DE STROOPER, B. \& SCORRANO, L. 2006. OPA1 Controls Apoptotic Cristae Remodeling Independently from Mitochondrial Fusion. Cell, 126, 177189.

FRIEDMAN, J. R., LACKNER, L. L., WEST, M., DIBENEDETTO, J. R., NUNNARI, J. \& VOELTZ, G. K. 2011. ER tubules mark sites of mitochondrial division. Science, 334, 358-362.

GANDRE-BABBE, S. \& VAN DER BLIEK, A. M. 2008. The novel tail-anchored membrane protein Mff controls mitochondrial and peroxisomal fission in mammalian cells. Molecular Biology of the Cell, 19, 2402-12.

GAO, K., LI, Y., HU, S. \& LIU, Y. 2019. SUMO peptidase ULP-4 regulates mitochondrial UPR-mediated innate immunity and lifespan extension. eLife, 8, e41792.

GEGG, M. E., COOPER, J. M., CHAU, K. Y., ROJO, M., SCHAPIRA, A. H. \& TAANMAN, J. W. 2010. Mitofusin 1 and mitofusin 2 are ubiquitinated in a PINK1/parkin-dependent manner upon induction of mitophagy. Human Molecular Genetics, 19, 4861-70.

GEHRKE, S., WU, Z., KLINKENBERG, M., SUN, Y., AUBURGER, G., GUO, S. \& LU, B. 2015. PINK1 and Parkin control localized translation of respiratory chain component mRNAs on mitochondria outer membrane. Cell Metabolism, 21, 95-108.

GELMETTI, V., DE ROSA, P., TOROSANTUCCI, L., MARINI, E. S., ROMAGNOLI, A., DI RIENZO, M., ARENA, G., VIGNONE, D., FIMIA, G. M. \& VALENTE, E. M. 2017. PINK1 and BECN1 relocalize at mitochondria-associated membranes during mitophagy and promote ER-mitochondria tethering and autophagosome formation. Autophagy, 13, 654-669.

GERBER, S., CHARIF, M., CHEVROLlier, A., CHAUMETTE, T., ANGEBAULT, C., KANE, M. S., PARIS, A., ALBAN, J., QUILES, M., DELETTRE, C., BONNEAU, D., PROCACCIO, V., AMATI-BONNEAU, P., REYNIER, P., LERUEZ, S., CALMON, R., BODDAERT, N., FUNALOT, B., RIO, M., BOUCCARA, D., MEUNIER, I., SESAKI, H., KAPLAN, J., HAMEL, C. P., ROZET, J. M. \& LENAERS, G. 2017. Mutations in DNM1L, as in OPA1, result in dominant optic atrophy despite opposite effects on mitochondrial fusion and fission. Brain, 140, 2586-2596.

GIACOMELLO, M., PYAKUREL, A., GLYTSOU, C. \& SCORRANO, L. 2020. The cell biology of mitochondrial membrane dynamics. Nature Reviews Molecular Cell Biology, 21, 204-224.

GISPERT, S., PARGANLIJA, D., KLINKENBERG, M., DRÖSE, S., WITTIG, I., MITTELBRONN, M., GRZMIL, P., KOOB, S., HAMANN, A., WALTER, M., BÜCHEL, F., ADLER, T., HRABÉ DE ANGELIS, M., BUSCH, D. H., ZELL, A., REICHERT, A. S., BRANDT, U., OSIEWACZ, H. D., JENDRACH, M. \& AUBURGER, G. 2013. Loss of mitochondrial peptidase Clpp leads to infertility, hearing loss plus growth retardation via accumulation of CLPX, mtDNA and inflammatory factors. Human Molecular Genetics, 22, 4871-4887.

GOMES, L. C., DI BENEDETTO, G. \& SCORRANO, L. 2011. During autophagy mitochondria elongate, are spared from degradation and sustain cell viability. Nature cell biology, 13, 589-598. 
GREENE, A. W., GRENIER, K., AGUILETA, M. A., MUISE, S., FARAZIFARD, R., HAQUE, M. E., MCBRIDE, H. M., PARK, D. S. \& FON, E. A. 2012. Mitochondrial processing peptidase regulates PINK1 processing, import and Parkin recruitment. EMBO reports, 13, 378-385.

GRIFFIN, E. E., GRAUMANN, J. \& CHAN, D. C. 2005. The WD40 protein Caf4p is a component of the mitochondrial fission machinery and recruits Dnm1p to mitochondria. Journal of Cell Biology, 170, 237-248.

GUO, X., AVILES, G., LIU, Y., TIAN, R., UNGER, B. A., LIN, Y.-H. T., WIITA, A. P., XU, K., CORREIA, M. A. \& KAMPMANN, M. 2020. Mitochondrial stress is relayed to the cytosol by an OMA1-DELE1-HRI pathway. Nature, 579, 427-432.

GUSTAFSSON, C. M., FALKENBERG, M. \& LARSSON, N.-G. 2016. Maintenance and Expression of Mammalian Mitochondrial DNA. Annual Review of Biochemistry, 85, 133-160.

HAMASAKI, M., FURUTA, N., MATSUDA, A., NEZU, A., YAMAMOTO, A., FUJITA, N., OOMORI, H., NODA, T., HARAGUCHI, T., HIRAOKA, Y., AMANO, A. \& YOSHIMORI, T. 2013. Autophagosomes form at ER-mitochondria contact sites. Nature, 495, 389-393.

HAO, Y.-H., ZHANG, J., WANG, H., WANG, H.-Y., DONG, J., XU, X.-P., YAO, B.-W., WANG, L.-F., ZHOU, H.M., ZHAO, L. \& PENG, R.-Y. 2018. HIF-1 $\alpha$ regulates COXIV subunits, a potential mechanism of self-protective response to microwave induced mitochondrial damages in neurons. Scientific Reports, 8, 10403.

HARTMANN, B., WAI, T., HU, H., MACVICAR, T., MUSANTE, L., FISCHER-ZIRNSAK, B., STENZEL, W., GRÄF, R., VAN DEN HEUVEL, L., ROPERS, H.-H., WIENKER, T. F., HÜBNER, C., LANGER, T. \& KAINDL, A. M. 2016. Homozygous YME1L1 mutation causes mitochondriopathy with optic atrophy and mitochondrial network fragmentation. eLife, 5, e16078.

HAYAKAWA, K., ESPOSITO, E., WANG, X., TERASAKI, Y., LIU, Y., XING, C., JI, X. \& LO, E. H. 2016. Transfer of mitochondria from astrocytes to neurons after stroke. Nature, 535, 551-555.

HAYNES, C. M., PETROVA, K., BENEDETTI, C., YANG, Y. \& RON, D. 2007. ClpP Mediates Activation of a Mitochondrial Unfolded Protein Response in C. elegans. Developmental Cell, 13, 467-480.

HAYNES, C. M., YANG, Y., BLAIS, S. P., NEUBERT, T. A. \& RON, D. 2010. The matrix peptide exporter HAF1 signals a mitochondrial UPR by activating the transcription factor ZC376.7 in C. elegans. Molecular Cell, 37, 529-40.

HE, G.-W., GÜNTHER, C., KREMER, A. E., THONN, V., AMANN, K., POREMBA, C., NEURATH, M. F., WIRTZ, S. \& BECKER, C. 2017. PGAM5-mediated programmed necrosis of hepatocytes drives acute liver injury. Gut, 66, 716-723.

HEAD, B., GRIPARIC, L., AMIRI, M., GANDRE-BABBE, S. \& VAN DER BLIEK, A. M. 2009. Inducible proteolytic inactivation of OPA1 mediated by the OMA1 protease in mammalian cells. Journal of Cell Biology, 187, 959-66.

HEO, J.-M., LIVNAT-LEVANON, N., TAYLOR, E. B., JONES, K. T., DEPHOURE, N., RING, J., XIE, J., BRODSKY, J. L., MADEO, F., GYGI, S. P., ASHRAFI, K., GLICKMAN, M. H. \& RUTTER, J. 2010. A StressResponsive System for Mitochondrial Protein Degradation. Molecular Cell, 40, 465-480.

HERLAN, M., VOGEL, F., BORNHOVD, C., NEUPERT, W. \& REICHERT, A. S. 2003. Processing of Mgm1 by the rhomboid-type protease Pcp1 is required for maintenance of mitochondrial morphology and of mitochondrial DNA. Journal of Biological Chemistry, 278, 27781-8.

HO, T. T., WARR, M. R., ADELMAN, E. R., LANSINGER, O. M., FLACH, J., VEROVSKAYA, E. V., FIGUEROA, M. E. \& PASSEGUÉ, E. 2017. Autophagy maintains the metabolism and function of young and old stem cells. Nature, 543, 205-210.

HUGHES, A. L., HUGHES, C. E., HENDERSON, K. A., YAZVENKO, N. \& GOTTSCHLING, D. E. 2016. Selective sorting and destruction of mitochondrial membrane proteins in aged yeast. eLife, 5, e13943.

HWANG, J. \& QI, L. 2018. Quality Control in the Endoplasmic Reticulum: Crosstalk between ERAD and UPR pathways. Trends in Biochemical Sciences, 43, 593-605. 
IKEDA, Y., SHIRAKABE, A., MAEJIMA, Y., ZHAI, P., SCIARRETTA, S., TOLI, J., NOMURA, M., MIHARA, K., EGASHIRA, K., OHISHI, M., ABDELLATIF, M. \& SADOSHIMA, J. 2015. Endogenous Drp1 Mediates Mitochondrial Autophagy and Protects the Heart Against Energy Stress. Circulation Research, $116,264-278$.

ISHIHARA, N., EURA, Y. \& MIHARA, K. 2004. Mitofusin 1 and 2 play distinct roles in mitochondrial fusion reactions via GTPase activity. Journal of Cell Science, 117, 6535-6546.

ITAKURA, E., KISHI-ITAKURA, C., KOYAMA-HONDA, I. \& MIZUSHIMA, N. 2012. Structures containing Atg9A and the ULK1 complex independently target depolarized mitochondria at initial stages of Parkin-mediated mitophagy. Journal of Cell Science, 125, 1488-1499.

IZAWA, T., PARK, S.-H., ZHAO, L., HARTL, F. U. \& NEUPERT, W. 2017. Cytosolic Protein Vms1 Links Ribosome Quality Control to Mitochondrial and Cellular Homeostasis. Cell, 171, 890-903.e18.

JACOBI, D., LIU, S., BURKEWITZ, K., KORY, N., KNUDSEN, N. H., ALEXANDER, R. K., UNLUTURK, U., LI, X., KONG, X., HYDE, A. L., GANGL, M. R., MAIR, W. B. \& LEE, C. H. 2015. Hepatic Bmal1 Regulates Rhythmic Mitochondrial Dynamics and Promotes Metabolic Fitness. Cell Metabolism, 22, 70920.

JACOUPY, M., HAMON-KEROMEN, E., ORDUREAU, A., ERPAPAZOGLOU, Z., COGE, F., CORVOL, J. C., NOSJEAN, O., MANNOURY LA COUR, C., MILLAN, M. J., BOUTIN, J. A., HARPER, J. W., BRICE, A., GUEDIN, D., GAUTIER, C. A. \& CORTI, O. 2019. The PINK1 kinase-driven ubiquitin ligase Parkin promotes mitochondrial protein import through the presequence pathway in living cells. Scientific Reports, 9, 11829.

JANG, S. C., CRESCITELLI, R., CVJETKOVIC, A., BELGRANO, V., OLOFSSON BAGGE, R., SUNDFELDT, K., OCHIYA, T., KALLURI, R. \& LÖTVALL, J. 2019. Mitochondrial protein enriched extracellular vesicles discovered in human melanoma tissues can be detected in patient plasma. Journal of Extracellular Vesicles, 8, 1635420.

JENKINSON, E. M., REHMAN, A. U., WALSH, T., CLAYTON-SMITH, J., LEE, K., MORELL, R. J., DRUMMOND, M. C., KHAN, S. N., NAEEM, M. A., RAUF, B., BILLINGTON, N., SCHULTZ, J. M., URQUHART, J. E., LEE, M. K., BERRY, A., HANLEY, N. A., MEHTA, S., CILLIERS, D., CLAYTON, P. E., KINGSTON, H., SMITH, M. J., WARNER, T. T., BLACK, G. C., TRUMP, D., DAVIS, J. R., AHMAD, W., LEAL, S. M., RIAZUDDIN, S., KING, M. C., FRIEDMAN, T. B. \& NEWMAN, W. G. 2013. Perrault syndrome is caused by recessive mutations in CLPP, encoding a mitochondrial ATP-dependent chambered protease. American Journal of Human Genetics, 92, 605-13.

JEON, H. B., CHOI, E. S., YOON, J. H., HWANG, J. H., CHANG, J. W., LEE, E. K., CHOI, H. W., PARK, Z.-Y. \& YOO, Y. J. 2007. A proteomics approach to identify the ubiquitinated proteins in mouse heart. Biochemical and Biophysical Research Communications, 357, 731-736.

JIN, S. M., LAZAROU, M., WANG, C., KANE, L. A., NARENDRA, D. P. \& YOULE, R. J. 2010. Mitochondrial membrane potential regulates PINK1 import and proteolytic destabilization by PARL. Journal of Cell Biology, 191, 933-942.

JOHANSEN, T. \& LAMARK, T. 2020. Selective Autophagy: ATG8 Family Proteins, LIR Motifs and Cargo Receptors. Journal of Molecular Biolology, 432, 80-103.

KAGEYAMA, Y., HOSHIJIMA, M., SEO, K., BEDJA, D., SYSA-SHAH, P., ANDRABI, S. A., CHEN, W., HÖKE, A., DAWSON, V. L., DAWSON, T. M., GABRIELSON, K., KASS, D. A., IIJIMA, M. \& SESAKI, H. 2014. Parkin-independent mitophagy requires Drp1 and maintains the integrity of mammalian heart and brain. The EMBO Journal, 33, 2798-2813.

KANE, L. A., LAZAROU, M., FOGEL, A. I., LI, Y., YAMANO, K., SARRAF, S. A., BANERJEE, S. \& YOULE, R. J. 2014. PINK1 phosphorylates ubiquitin to activate Parkin E3 ubiquitin ligase activity. Journal of Cell Biology, 205, 143-153. 
KANG, Y. J., BANG, B.-R., HAN, K. H., HONG, L., SHIM, E.-J., MA, J., LERNER, R. A. \& OTSUKA, M. 2015. Regulation of NKT cell-mediated immune responses to tumours and liver inflammation by mitochondrial PGAM5-Drp1 signalling. Nature Communications, 6, 8371.

KANKI, T. \& KLIONSKY, D. J. 2008. Mitophagy in yeast occurs through a selective mechanism. Journal of Biological Chemistry, 283, 32386-32393.

KARBOWSKI, M., NEUTZNER, A. \& YOULE, R. J. 2007. The mitochondrial E3 ubiquitin ligase MARCH5 is required for Drp1 dependent mitochondrial division. Journal of Cell Biology, 178, 71-84.

KATHEDER, N. S., KHEZRI, R., O'FARRELL, F., SCHULTZ, S. W., JAIN, A., RAHMAN, M. M., SCHINK, K. O., THEODOSSIOU, T. A., JOHANSEN, T., JUHÁSZ, G., BILDER, D., BRECH, A., STENMARK, H. \& RUSTEN, T. E. 2017. Microenvironmental autophagy promotes tumour growth. Nature, 541, 417-420.

KAUFMAN, B. A., DURISIC, N., MATIVETSKY, J. M., COSTANTINO, S., HANCOCK, M. A., GRUTTER, P. \& SHOUBRIDGE, E. A. 2007. The mitochondrial transcription factor TFAM coordinates the assembly of multiple DNA molecules into nucleoid-like structures. Molecular Biology of the Cell, 18, 32253236.

KHACHO, M., TARABAY, M., PATTEN, D., KHACHO, P., MACLAURIN, J. G., GUADAGNO, J., BERGERON, R., CREGAN, S. P., HARPER, M.-E., PARK, D. S. \& SLACK, R. S. 2014. Acidosis overrides oxygen deprivation to maintain mitochondrial function and cell survival. Nature Communications, 5, 3550 .

KHALIL, B., EL FISSI, N., AOUANE, A., CABIROL-POL, M. J., RIVAL, T. \& LIÉVENS, J. C. 2015. PINK1-induced mitophagy promotes neuroprotection in Huntington's disease. Cell death \& disease, 6, e1617e1617.

KHALIMONCHUK, O., JEONG, M.-Y., WATTS, T., FERRIS, E. \& WINGE, D. R. 2012. Selective Oma1 Protease-mediated Proteolysis of Cox1 Subunit of Cytochrome Oxidase in Assembly Mutants. Journal of Biological Chemistry, 287, 7289-7300.

KIM, T. Y., WANG, D., KIM, A. K., LAU, E., LIN, A. J., LIEM, D. A., ZHANG, J., ZONG, N. C., LAM, M. P. \& PING, P. 2012. Metabolic labeling reveals proteome dynamics of mouse mitochondria. Molecular and Cellular Proteomics, 11, 1586-94.

KIM, Y. Y., UM, J. H., YOON, J. H., KIM, H., LEE, D. Y., LEE, Y. J., JEE, H. J., KIM, Y. M., JANG, J. S., JANG, Y. G., CHUNG, J., PARK, H. T., FINKEL, T., KOH, H. \& YUN, J. 2019. Assessment of mitophagy in mtKeima Drosophila revealed an essential role of the PINK1-Parkin pathway in mitophagy induction in vivo. The FASEB Journal, 33, 9742-9751.

KITADA, T., ASAKAWA, S., HATTORI, N., MATSUMINE, H., YAMAMURA, Y., MINOSHIMA, S., YOKOCHI, M., MIZUNO, Y. \& SHIMIZU, N. 1998. Mutations in the parkin gene cause autosomal recessive juvenile parkinsonism. Nature, 392, 605-8.

KOCH, A., THIEMANN, M., GRABENBAUER, M., YOON, Y., MCNIVEN, M. A. \& SCHRADER, M. 2003. Dynamin-like protein 1 is involved in peroxisomal fission. Journal of Biological Chemistry, 278, 8597-605.

KOCH, J., FEICHTINGER, R. G., FREISINGER, P., PIES, M., SCHRÖDL, F., IUSO, A., SPERL, W., MAYR, J. A., PROKISCH, H. \& HAACK, T. B. 2016. Disturbed mitochondrial and peroxisomal dynamics due to loss of MFF causes Leigh-like encephalopathy, optic atrophy and peripheral neuropathy. Journal of Medical Genetics, 53, 270-8.

KOROBOVA, F., RAMABHADRAN, V. \& HIGGS, H. N. 2013. An actin-dependent step in mitochondrial fission mediated by the ER-associated formin INF2. Science, 339, 464-7.

KORWITZ, A., MERKWIRTH, C., RICHTER-DENNERLEIN, R., TRÖDER, S. E., SPRENGER, H. G., QUIRÓS, P. M., LÓPEZ-OTÍN, C., RUGARLI, E. I. \& LANGER, T. 2016. Loss of OMA1 delays neurodegeneration by preventing stress-induced OPA1 processing in mitochondria. Journal of Cell Biology, 212, 15766. 
KOYANO, F., YAMANO, K., KOSAKO, H., TANAKA, K. \& MATSUDA, N. 2019. Parkin recruitment to impaired mitochondria for nonselective ubiquitylation is facilitated by MITOL. Journal of Biological Chemistry, 294, 10300-10314.

KUANG, Y., MA, K., ZHOU, C., DING, P., ZHU, Y., CHEN, Q. \& XIA, B. 2016. Structural basis for the phosphorylation of FUNDC1 LIR as a molecular switch of mitophagy. Autophagy, 12, 2363-2373.

KUBLI, D. A., CORTEZ, M. Q., MOYZIS, A. G., NAJOR, R. H., LEE, Y. \& GUSTAFSSON Å, B. 2015. PINK1 Is Dispensable for Mitochondrial Recruitment of Parkin and Activation of Mitophagy in Cardiac Myocytes. PLoS One, 10, e0130707.

KUROHA, K., ZINOVIEV, A., HELLEN, C. U. T. \& PESTOVA, T. V. 2018. Release of Ubiquitinated and Nonubiquitinated Nascent Chains from Stalled Mammalian Ribosomal Complexes by ANKZF1 and Ptrh1. Molecular Cell, 72, 286-302.e8.

KÖNIG, T., TRÖDER, S. E., BAKKA, K., KORWITZ, A., RICHTER-DENNERLEIN, R., LAMPE, P. A., PATRON, M., MÜHLMEISTER, M., GUERRERO-CASTILLO, S., BRANDT, U., DECKER, T., LAURIA, I., PAGGIO, A., RIZZUTO, R., RUGARLI, E. I., DE STEFANI, D. \& LANGER, T. 2016. The m-AAA Protease Associated with Neurodegeneration Limits MCU Activity in Mitochondria. Molecular Cell, 64, 148-162.

LABROUSSE, A. M., ZAPPATERRA, M. D., RUBE, D. A. \& VAN DER BLIEK, A. M. 1999. C. elegans DynaminRelated Protein DRP-1 Controls Severing of the Mitochondrial Outer Membrane. Molecular Cell, 4, 815-826.

LAGOUGE, M., MOURIER, A., LEE, H. J., SPÅHR, H., WAI, T., KUKAT, C., SILVA RAMOS, E., MOTORI, E., BUSCH, J. D., SIIRA, S., GERMAN MOUSE CLINIC, C., KREMMER, E., FILIPOVSKA, A. \& LARSSON, N.-G. 2015. SLIRP Regulates the Rate of Mitochondrial Protein Synthesis and Protects LRPPRC from Degradation. PLoS Genetics, 11, e1005423.

LAVIE, J., DE BELVALET, H., SONON, S., ION, A. M., DUMON, E., MELSER, S., LACOMBE, D., DUPUY, J. W., LALOU, C. \& BÉNARD, G. 2018. Ubiquitin-Dependent Degradation of Mitochondrial Proteins Regulates Energy Metabolism. Cell Reports, 23, 2852-2863.

LAZAROU, M., JIN, SEOK M., KANE, LESLEY A. \& YOULE, RICHARD J. 2012. Role of PINK1 Binding to the TOM Complex and Alternate Intracellular Membranes in Recruitment and Activation of the E3 Ligase Parkin. Developmental Cell, 22, 320-333.

LAZAROU, M., SLITER, D. A., KANE, L. A., SARRAF, S. A., WANG, C., BURMAN, J. L., SIDERIS, D. P., FOGEL, A. I. \& YOULE, R. J. 2015. The ubiquitin kinase PINK1 recruits autophagy receptors to induce mitophagy. Nature, 524, 309-314.

LE GUERROUÉ, F., ECK, F., JUNG, J., STARZETZ, T., MITTELBRONN, M., KAULICH, M. \& BEHRENDS, C. 2017. Autophagosomal Content Profiling Reveals an LC3C-Dependent Piecemeal Mitophagy Pathway. Molecular Cell, 68, 786-796.e6.

LEBOUCHER, G. P., TSAI, Y. C., YANG, M., SHAW, K. C., ZHOU, M., VEENSTRA, T. D., GLICKMAN, M. H. \& WEISSMAN, A. M. 2012. Stress-induced phosphorylation and proteasomal degradation of mitofusin 2 facilitates mitochondrial fragmentation and apoptosis. Molecular Cell, 47, 547-57.

LEE, H., SMITH, S. B. \& YOON, Y. 2017. The short variant of the mitochondrial dynamin OPA1 maintains mitochondrial energetics and cristae structure. Journal of Biological Chemistry, 292, 7115-7130.

LEE, J. J., SANCHEZ-MARTINEZ, A., ZARATE, A. M., BENINCÁ, C., MAYOR, U., CLAGUE, M. J. \& WHITWORTH, A. J. 2018a. Basal mitophagy is widespread in Drosophila but minimally affected by loss of Pink1 or parkin. Journal of Cell Biology, 217, 1613-1622.

LEE, K.-S., HUH, S., LEE, S., WU, Z., KIM, A.-K., KANG, H.-Y. \& LU, B. 2018b. Altered ER-mitochondria contact impacts mitochondria calcium homeostasis and contributes to neurodegeneration in vivo in disease models. Proceedings of the National Academy of Sciences, 115, E8844-E8853.

LEHMANN, G., ZIV, T., BRATEN, O., ADMON, A., UDASIN, R. G. \& CIECHANOVER, A. 2016. Ubiquitination of specific mitochondrial matrix proteins. Biochemical and Biophysical Research Communications, 475, 13-18. 
LEMASTERS, J. J. 2005. Selective mitochondrial autophagy, or mitophagy, as a targeted defense against oxidative stress, mitochondrial dysfunction, and aging. Rejuvenation Res, 8, 3-5.

LEONHARD, K., STIEGLER, A., NEUPERT, W. \& LANGER, T. 1999. Chaperone-like activity of the AAA domain of the yeast Yme1 AAA protease. Nature, 398, 348-351.

LEWIS, S. C., UCHIYAMA, L. F. \& NUNNARI, J. 2016. ER-mitochondria contacts couple mtDNA synthesis with mitochondrial division in human cells. Science, 353, aaf5549.

LI, B., ZHAO, H., WU, Y., ZHU, Y., ZHANG, J., YANG, G., YAN, Q., LI, J., LI, T. \& LIU, L. 2020. MitochondrialDerived Vesicles Protect Cardiomyocytes Against Hypoxic Damage. Frontiers in Cell and Developmental Biology, 8.

LIAO, P.-C., WOLKEN, D. M. A., SERRANO, E., SRIVASTAVA, P. \& PON, L. A. 2020. MitochondriaAssociated Degradation Pathway (MAD) Function beyond the Outer Membrane. Cell Reports, 32, 107902.

LITONIN, D., SOLOGUB, M., SHI, Y., SAVKINA, M., ANIKIN, M., FALKENBERG, M., GUSTAFSSON, C. M. \& TEMIAKOV, D. 2010. Human mitochondrial transcription revisited: only TFAM and TFB2M are required for transcription of the mitochondrial genes in vitro. Journal of Biological Chemistry, 285, 18129-18133.

LIU, K., JI, K., GUO, L., WU, W., LU, H., SHAN, P. \& YAN, C. 2014. Mesenchymal stem cells rescue injured endothelial cells in an in vitro ischemia-reperfusion model via tunneling nanotube like structure-mediated mitochondrial transfer. Microvascular Research, 92, 10-18.

LIU, L., FENG, D., CHEN, G., CHEN, M., ZHENG, Q., SONG, P., MA, Q., ZHU, C., WANG, R., QI, W., HUANG, L., XUE, P., LI, B., WANG, X., JIN, H., WANG, J., YANG, F., LIU, P., ZHU, Y., SUI, S. \& CHEN, Q. 2012. Mitochondrial outer-membrane protein FUNDC1 mediates hypoxia-induced mitophagy in mammalian cells. Nature Cell Biology, 14, 177-185.

LOH, J. K., LIN, C. C., YANG, M. C., CHOU, C. H., CHEN, W. S., HONG, M. C., CHO, C. L., HSU, C. M., CHENG, J. T., CHOU, A. K., CHANG, C. H., TSENG, C. N., WANG, C. H., LIEU, A. S., HOWNG, S. L. \& HONG, Y. R. 2015. GSKIP- and GSK3-mediated anchoring strengthens CAMP/PKA/Drp1 axis signaling in the regulation of mitochondrial elongation. Biochimica et Biophysica Acta (BBA) - Molecular Cell Research, 1853, 1796-807.

LOSÓN, O. C., SONG, Z., CHEN, H. \& CHAN, D. C. 2013. Fis1, Mff, MiD49, and MiD51 mediate Drp1 recruitment in mitochondrial fission. Molecular Biology of the Cell, 24, 659-67.

LU, J., ZHENG, X., LI, F., YU, Y., CHEN, Z., LIU, Z., WANG, Z., XU, H. \& YANG, W. 2017. Tunneling nanotubes promote intercellular mitochondria transfer followed by increased invasiveness in bladder cancer cells. Oncotarget, 8, 15539-15552.

LUCE, K. \& OSIEWACZ, H. D. 2009. Increasing organismal healthspan by enhancing mitochondrial protein quality control. Nature Cell Biology, 11, 852-858.

MACVICAR, T. \& LANGER, T. 2016. OPA1 processing in cell death and disease - the long and short of it. Journal of Cell Science, 129, 2297-306.

MACVICAR, T., OHBA, Y., NOLTE, H., MAYER, F. C., TATSUTA, T., SPRENGER, H.-G., LINDNER, B., ZHAO, Y., LI, J., BRUNS, C., KRÜGER, M., HABICH, M., RIEMER, J., SCHWARZER, R., PASPARAKIS, M., HENSCHKE, S., BRÜNING, J. C., ZAMBONI, N. \& LANGER, T. 2019. Lipid signalling drives proteolytic rewiring of mitochondria by YME1L. Nature, 575, 361-365.

MANOR, U., BARTHOLOMEW, S., GOLANI, G., CHRISTENSON, E., KOZLOV, M., HIGGS, H., SPUDICH, J. \& LIPPINCOTT-SCHWARTZ, J. 2015. A mitochondria-anchored isoform of the actin-nucleating spire protein regulates mitochondrial division. eLife, 4, e08828.

MAO, K., WANG, K., LIU, X. \& KLIONSKY, DANIEL J. 2013. The Scaffold Protein Atg11 Recruits Fission Machinery to Drive Selective Mitochondria Degradation by Autophagy. Developmental Cell, 26, 9-18. 
MATHIVANAN, S., FAHNER, C. J., REID, G. E. \& SIMPSON, R. J. 2012. ExoCarta 2012: database of exosomal proteins, RNA and lipids. Nucleic acids research, 40, D1241-D1244.

MATSUMOTO, S., NAKATSUKASA, K., KAKUTA, C., TAMURA, Y., ESAKI, M. \& ENDO, T. 2019. Msp1 Clears Mistargeted Proteins by Facilitating Their Transfer from Mitochondria to the ER. Molecular Cell, 76, 191-205.e10.

MATSUSHIMA, Y., GOTO, Y. \& KAGUNI, L. S. 2010. Mitochondrial Lon protease regulates mitochondrial DNA copy number and transcription by selective degradation of mitochondrial transcription factor A (TFAM). Proceedings of the National Academy of Sciences, 107, 18410-5.

MATSUSHIMA, Y., HIROFUJI, Y., AIHARA, M., YUE, S., UCHIUMI, T., KAGUNI, L. S. \& KANG, D. 2017. Drosophila protease CIpXP specifically degrades DmLRPPRC1 controlling mitochondrial mRNA and translation. Scientific Reports, 7, 8315.

MCLELLAND, G.-L., GOIRAN, T., YI, W., DORVAL, G., CHEN, C. X., LAUINGER, N. D., KRAHN, A. I., VALIMEHR, S., RAKOVIC, A., ROUILLER, I., DURCAN, T. M., TREMPE, J.-F. \& FON, E. A. 2018. Mfn2 ubiquitination by PINK1/parkin gates the p97-dependent release of ER from mitochondria to drive mitophagy. eLife, 7, e32866.

MCLELLAND, G.-L., LEE, S. A., MCBRIDE, H. M. \& FON, E. A. 2016. Syntaxin-17 delivers PINK1/parkindependent mitochondrial vesicles to the endolysosomal system. Journal of Cell Biology, 214, 275-291.

MCLELLAND, G. L., SOUBANNIER, V., CHEN, C. X., MCBRIDE, H. M. \& FON, E. A. 2014. Parkin and PINK1 function in a vesicular trafficking pathway regulating mitochondrial quality control. The EMBO Journal, 33, 282-95.

MCQUIBBAN, G. A., SAURYA, S. \& FREEMAN, M. 2003. Mitochondrial membrane remodelling regulated by a conserved rhomboid protease. Nature, 423, 537-41.

MCWILLIAMS, T. G., PRESCOTT, A. R., MONTAVA-GARRIGA, L., BALL, G., SINGH, F., BARINI, E., MUQIT, M. M. K., BROOKS, S. P. \& GANLEY, I. G. 2018. Basal Mitophagy Occurs Independently of PINK1 in Mouse Tissues of High Metabolic Demand. Cell Metabolism, 27, 439-449.e5.

MELENTIJEVIC, I., TOTH, M. L., ARNOLD, M. L., GUASP, R. J., HARINATH, G., NGUYEN, K. C., TAUB, D., PARKER, J. A., NERI, C., GABEL, C. V., HALL, D. H. \& DRISCOLL, M. 2017. C. elegans neurons jettison protein aggregates and mitochondria under neurotoxic stress. Nature, 542, 367-371.

MENDL, N., OCCHIPINTI, A., MÜLLER, M., WILD, P., DIKIC, I. \& REICHERT, A. S. 2011. Mitophagy in yeast is independent of mitochondrial fission and requires the stress response gene WHI2. Journal of Cell Science, 124, 1339-1350.

MORGENSTERN, M., STILLER, S. B., LÜBBERT, P., PEIKERT, C. D., DANNENMAIER, S., DREPPER, F., WEILL, U., HÖß, P., FEUERSTEIN, R., GEBERT, M., BOHNERT, M., VAN DER LAAN, M., SCHULDINER, M., SCHÜTZE, C., OELJEKLAUS, S., PFANNER, N., WIEDEMANN, N. \& WARSCHEID, B. 2017. Definition of a High-Confidence Mitochondrial Proteome at Quantitative Scale. Cell Reports, 19, 28362852.

MORITA, M., PRUDENT, J., BASU, K., GOYON, V., KATSUMURA, S., HULEA, L., PEARL, D., SIDDIQUI, N., STRACK, S., MCGUIRK, S., ST-PIERRE, J., LARSSON, O., TOPISIROVIC, I., VALI, H., MCBRIDE, H. M., BERGERON, J. J. \& SONENBERG, N. 2017. mTOR Controls Mitochondrial Dynamics and Cell Survival via MTFP1. Mol Cell, 67, 922-935.e5.

MOTTIS, A., HERZIG, S. \& AUWERX, J. 2019. Mitocellular communication: Shaping health and disease. Science, 366, 827-832.

MURAKAWA, T., YAMAGUCHI, O., HASHIMOTO, A., HIKOSO, S., TAKEDA, T., OKA, T., YASUI, H., UEDA, H., AKAZAWA, Y., NAKAYAMA, H., TANEIKE, M., MISAKA, T., OMIYA, S., SHAH, A. M., YAMAMOTO, A., NISHIDA, K., OHSUMI, Y., OKAMOTO, K., SAKATA, Y. \& OTSU, K. 2015. Bcl-2-like protein 13 is a mammalian Atg32 homologue that mediates mitophagy and mitochondrial fragmentation. Nature Communications, 6, 7527. 
MÜNCH, C. \& HARPER, J. W. 2016. Mitochondrial unfolded protein response controls matrix pre-RNA processing and translation. Nature, 534, 710-713.

MÅRTENSSON, C. U., PRIESNITZ, C., SONG, J., ELLENRIEDER, L., DOAN, K. N., BOOS, F., FLOERCHINGER, A., ZUFALL, N., OELJEKLAUS, S., WARSCHEID, B. \& BECKER, T. 2019. Mitochondrial protein translocation-associated degradation. Nature, 569, 679-683.

NAGASHIMA, S., TÁBARA, L.-C., TILOKANI, L., PAUPE, V., ANAND, H., POGSON, J. H., ZUNINO, R., MCBRIDE, H. M. \& PRUDENT, J. 2020. Golgi-derived PI (4) P-containing vesicles drive late steps of mitochondrial division. Science, 367, 1366-1371.

NAGASHIMA, S., TOKUYAMA, T., YONASHIRO, R., INATOME, R. \& YANAGI, S. 2014. Roles of mitochondrial ubiquitin ligase MITOL/MARCH5 in mitochondrial dynamics and diseases. Journal of Biochemistry, 155, 273-279.

NAKADA, K., INOUE, K. \& HAYASHI, J.-I. 2001. Interaction Theory of Mammalian Mitochondria. Biochemical and Biophysical Research Communications, 288, 743-746.

NAON, D., ZANINELLO, M., GIACOMELLO, M., VARANITA, T., GRESPI, F., LAKSHMINARANAYAN, S., SERAFINI, A., SEMENZATO, M., HERKENNE, S., HERNÁNDEZ-ALVAREZ, M. I., ZORZANO, A., DE STEFANI, D., DORN, G. W. \& SCORRANO, L. 2016. Critical reappraisal confirms that Mitofusin 2 is an endoplasmic reticulum-mitochondria tether. Proceedings of the National Academy of Sciences, 113, 11249-11254.

NAON, D., ZANINELLO, M., GIACOMELLO, M., VARANITA, T., GRESPI, F., LAKSHMINARANAYAN, S., SERAFINI, A., SEMENZATO, M., HERKENNE, S., HERNÁNDEZ-ALVAREZ, M. I., ZORZANO, A., DE STEFANI, D., DORN, G. W. \& SCORRANO, L. 2017. Reply to Filadi et al.: Does Mitofusin 2 tether or separate endoplasmic reticulum and mitochondria? Proceedings of the National Academy of Sciences, 114, E2268-E2269.

NARENDRA, D., TANAKA, A., SUEN, D.-F. \& YOULE, R. J. 2008. Parkin is recruited selectively to impaired mitochondria and promotes their autophagy. Journal of Cell Biology, 183, 795-803.

NARGUND, A. M., FIORESE, C. J., PELLEGRINO, M. W., DENG, P. \& HAYNES, C. M. 2015. Mitochondrial and nuclear accumulation of the transcription factor ATFS-1 promotes OXPHOS recovery during the UPR(mt). Molecular Cell, 58, 123-33.

NARGUND, A. M., PELLEGRINO, M. W., FIORESE, C. J., BAKER, B. M. \& HAYNES, C. M. 2012. Mitochondrial import efficiency of ATFS-1 regulates mitochondrial UPR activation. Science, 337, 587-90.

NEUPERT, W. \& HERRMANN, J. M. 2007. Translocation of Proteins into Mitochondria. Annual Review of Biochemistry, 76, 723-749.

NEUSPIEL, M., SCHAUSS, A. C., BRASCHI, E., ZUNINO, R., RIPPSTEIN, P., RACHUBINSKI, R. A., ANDRADENAVARRO, M. A. \& MCBRIDE, H. M. 2008. Cargo-Selected Transport from the Mitochondria to Peroxisomes Is Mediated by Vesicular Carriers. Current Biology, 18, 102-108.

NGUYEN, T. D., SHAID, S., VAKHRUSHEVA, O., KOSCHADE, S. E., KLANN, K., THÖLKEN, M., BAKER, F., ZHANG, J., OELLERICH, T., SÜRÜN, D., DERLET, A., HABERBOSCH, I., EIMER, S., OSIEWACZ, H. D., BEHRENDS, C., MÜNCH, C., DIKIC, I. \& BRANDTS, C. H. 2019. Loss of the selective autophagy receptor p62 impairs murine myeloid leukemia progression and mitophagy. Blood, 133, 168179.

NGUYEN, T. N., PADMAN, B. S., USHER, J., OORSCHOT, V., RAMM, G. \& LAZAROU, M. 2016. Atg8 family LC3/GABARAP proteins are crucial for autophagosome-lysosome fusion but not autophagosome formation during PINK1/Parkin mitophagy and starvation. Journal of Cell Biology, 215, 857-874.

NICOLÁS-ÁVILA, J. A., LECHUGA-VIECO, A. V., ESTEBAN-MARTÍNEZ, L., SÁNCHEZ-DÍAZ, M., DÍAZ-GARCÍA, E., SANTIAGO, D. J., RUBIO-PONCE, A., LI, J. L., BALACHANDER, A., QUINTANA, J. A., MARTÍNEZDE-MENA, R., CASTEJÓN-VEGA, B., PUN-GARCÍA, A., TRAVÉS, P. G., BONZÓN-KULICHENKO, E., GARCÍA-MARQUÉS, F., CUSSÓ, L., A-GONZÁLEZ, N., GONZÁLEZ-GUERRA, A., ROCHE-MOLINA, M., 
MARTIN-SALAMANCA, S., CRAINICIUC, G., GUZMÁN, G., LARRAZABAL, J., HERRERO-GALÁN, E., ALEGRE-CEBOLLADA, J., LEMKE, G., ROTHLIN, C. V., JIMENEZ-BORREGUERO, L. J., REYES, G., CASTRILLO, A., DESCO, M., MUÑOZ-CÁNOVES, P., IBÁÑEZ, B., TORRES, M., NG, L. G., PRIORI, S. G., BUENO, H., VÁZQUEZ, J., CORDERO, M. D., BERNAL, J. A., ENRÍQUEZ, J. A. \& HIDALGO, A. 2020. A Network of Macrophages Supports Mitochondrial Homeostasis in the Heart. Cell, 183, 94-109.e23.

NOLDEN, M., EHSES, S., KOPPEN, M., BERNACCHIA, A., RUGARLI, E. I. \& LANGER, T. 2005. The m-AAA Protease Defective in Hereditary Spastic Paraplegia Controls Ribosome Assembly in Mitochondria. Cell, 123, 277-289.

OKAMOTO, K., KONDO-OKAMOTO, N. \& OHSUMI, Y. 2009. Mitochondria-Anchored Receptor Atg32 Mediates Degradation of Mitochondria via Selective Autophagy. Developmental Cell, 17, 87-97.

OKATSU, K., KOYANO, F., KIMURA, M., KOSAKO, H., SAEKI, Y., TANAKA, K. \& MATSUDA, N. 2015. Phosphorylated ubiquitin chain is the genuine Parkin receptor. Journal of Cell Biology, 209, 11128.

OLÁHOVÁ, M., THOMPSON, K., HARDY, S. A., BARBOSA, I. A., BESSE, A., ANAGNOSTOU, M. E., WHITE, K., DAVEY, T., SIMPSON, M. A., CHAMPION, M., ENNS, G., SCHELLEY, S., LIGHTOWLERS, R. N., CHRZANOWSKA-LIGHTOWLERS, Z. M., MCFARLAND, R., DESHPANDE, C., BONNEN, P. E. \& TAYLOR, R. W. 2017. Pathogenic variants in HTRA2 cause an early-onset mitochondrial syndrome associated with 3-methylglutaconic aciduria. Journal of Inherited Metabolic Disease, 40, 121-130.

OLICHON, A., BARICAULT, L., GAS, N., GUILLOU, E., VALETTE, A., BELENGUER, P. \& LENAERS, G. 2003. Loss of OPA1 perturbates the mitochondrial inner membrane structure and integrity, leading to cytochrome c release and apoptosis. Journal of Biological Chemistry, 278, 7743-6.

ONOUE, K., JOFUKU, A., BAN-ISHIHARA, R., ISHIHARA, T., MAEDA, M., KOSHIBA, T., ITOH, T., FUKUDA, M., OTERA, H., OKA, T., TAKANO, H., MIZUSHIMA, N., MIHARA, K. \& ISHIHARA, N. 2013. Fis1 acts as a mitochondrial recruitment factor for TBC1D15 that is involved in regulation of mitochondrial morphology. Journal of Cell Science, 126, 176-85.

OSELLAME, L. D., SINGH, A. P., STROUD, D. A., PALMER, C. S., STOJANOVSKI, D., RAMACHANDRAN, R. \& RYAN, M. T. 2016. Cooperative and independent roles of the Drp1 adaptors Mff, MiD49 and MiD51 in mitochondrial fission. Journal of Cell Science, 129, 2170-81.

OSMAN, C., MERKWIRTH, C. \& LANGER, T. 2009. Prohibitins and the functional compartmentalization of mitochondrial membranes. Journal of Cell Science, 122, 3823-3830.

OTSUGA, D., KEEGAN, B. R., BRISCH, E., THATCHER, J. W., HERMANN, G. J., BLEAZARD, W. \& SHAW, J. M. 1998. The Dynamin-related GTPase, Dnm1p, Controls Mitochondrial Morphology in Yeast. Journal of Cell Biology, 143, 333-349.

PADMAN, B. S., NGUYEN, T. N., UOSELIS, L., SKULSUPPAISARN, M., NGUYEN, L. K. \& LAZAROU, M. 2019. LC3/GABARAPs drive ubiquitin-independent recruitment of Optineurin and NDP52 to amplify mitophagy. Nature Communications, 10, 408.

PALMER, C. S., OSELLAME, L. D., LAINE, D., KOUTSOPOULOS, O. S., FRAZIER, A. E. \& RYAN, M. T. 2011. MiD49 and MiD51, new components of the mitochondrial fission machinery. EMBO reports, 12, 565-73.

PAPA, L. \& GERMAIN, D. 2011. Estrogen receptor mediates a distinct mitochondrial unfolded protein response. Journal of cell science, 124, 1396-1402.

PAPA, L. \& GERMAIN, D. 2014. SirT3 regulates the mitochondrial unfolded protein response. Molecular and Cellular Biology, 34, 699-710.

PARK, Y.-Y., LEE, S., KARBOWSKI, M., NEUTZNER, A., YOULE, R. J. \& CHO, H. 2010. LosS of MARCH5 mitochondrial E3 ubiquitin ligase induces cellular senescence through dynamin-related protein 1 and mitofusin 1. Journal of Cell Science, 123, 619-626. 
PATIL, H., YOON, D., BHOWMICK, R., CAI, Y., CHO, K. I. \& FERREIRA, P. A. 2019. Impairments in agedependent ubiquitin proteostasis and structural integrity of selective neurons by uncoupling Ran GTPase from the Ran-binding domain 3 of Ranbp2 and identification of novel mitochondrial isoforms of ubiquitin-conjugating enzyme E2I (ubc9) and Ranbp2. Small GTPases, 10, 146-161.

PENG, W., WONG, Y. C. \& KRAINC, D. 2020. Mitochondria-lysosome contacts regulate mitochondrial Ca2+ dynamics via lysosomal TRPML1. Proceedings of the National Academy of Sciences, 117, 19266-19275.

PERNAS, L. \& SCORRANO, L. 2016. Mito-Morphosis: Mitochondrial Fusion, Fission, and Cristae Remodeling as Key Mediators of Cellular Function. Annual Review of Physiology, 78, 505-531.

PETER, B., WADDINGTON, C. L., OLÁHOVÁ, M., SOMMERVILLE, E. W., HOPTON, S., PYLE, A., CHAMPION, M., OHLSON, M., SIIBAK, T., CHRZANOWSKA-LIGHTOWLERS, Z. M. A., TAYLOR, R. W., FALKENBERG, M. \& LIGHTOWLERS, R. N. 2018. Defective mitochondrial protease LonP1 can cause classical mitochondrial disease. Human Molecular Genetics, 27, 1743-1753.

PHU, L., ROSE, C. M., TEA, J. S., WALL, C. E., VERSCHUEREN, E., CHEUNG, T. K., KIRKPATRICK, D. S. \& BINGOL, B. 2020. Dynamic Regulation of Mitochondrial Import by the Ubiquitin System. Molecular Cell, 77, 1107-1123.e10.

PICCA, A., GUERRA, F., CALVANI, R., MARINI, F., BIANCOLILLO, A., LANDI, G., BELI, R., LANDI, F., BERNABEI, R., BENTIVOGLIO, A. R., MONACO, M. R. L., BUCCI, C. \& MARZETTI, E. 2020. Mitochondrial Signatures in Circulating Extracellular Vesicles of Older Adults with Parkinson's Disease: Results from the EXosomes in PArkiNson's Disease (EXPAND) Study. Journal of Clinical Medicine, 9.

PITTS, K. R., YOON, Y., KRUEGER, E. W. \& MCNIVEN, M. A. 1999. The dynamin-like protein DLP1 is essential for normal distribution and morphology of the endoplasmic reticulum and mitochondria in mammalian cells. Molecular Biology of the Cell, 10, 4403-4417.

POTTING, C., TATSUTA, T., KÖNIG, T., HAAG, M., WAI, T., AALTONEN, M. J. \& LANGER, T. 2013. TRIAP1/PRELI complexes prevent apoptosis by mediating intramitochondrial transport of phosphatidic acid. Cell Metabolism, 18, 287-95.

PRIETO, J., LEÓN, M., PONSODA, X., SENDRA, R., BORT, R., FERRER-LORENTE, R., RAYA, A., LÓPEZGARCÍA, C. \& TORRES, J. 2016. Early ERK1/2 activation promotes DRP1-dependent mitochondrial fission necessary for cell reprogramming. Nature Communications, 7, 11124.

PRINCELY ABUDU, Y., PANKIV, S., MATHAI, B. J., HÅKON LYSTAD, A., BINDESB $\varnothing L L$, C., BRENNE, H. B., YOKE WUI NG, M., THIEDE, B., YAMAMOTO, A., MUTUGI NTHIGA, T., LAMARK, T., ESGUERRA, C. V., JOHANSEN, T. \& SIMONSEN, A. 2019. NIPSNAP1 and NIPSNAP2 Act as "Eat Me" Signals for Mitophagy. Developmental Cell, 49, 509-525.e12.

PRUDENT, J., ZUNINO, R., SUGIURA, A., MATTIE, S., SHORE, G. C. \& MCBRIDE, H. M. 2015. MAPL SUMOylation of Drp1 Stabilizes an ER/Mitochondrial Platform Required for Cell Death. Molecular Cell, 59, 941-55.

PUHM, F., AFONYUSHKIN, T., RESCH, U., OBERMAYER, G., ROHDE, M., PENZ, T., SCHUSTER, M., WAGNER, G., RENDEIRO, A. F., MELKI, I., KAUN, C., WOJTA, J., BOCK, C., JILMA, B., MACKMAN, N., BOILARD, E. \& BINDER, C. J. 2019. Mitochondria Are a Subset of Extracellular Vesicles Released by Activated Monocytes and Induce Type I IFN and TNF Responses in Endothelial Cells. Circulation Research, 125, 43-52.

PYAKUREL, A., SAVOIA, C., HESS, D. \& SCORRANO, L. 2015. Extracellular regulated kinase phosphorylates mitofusin 1 to control mitochondrial morphology and apoptosis. Molecular Cell, 58, 244-54.

QIAN, W., CHOI, S., GIBSON, G. A., WATKINS, S. C., BAKKENIST, C. J. \& VAN HOUTEN, B. 2012. Mitochondrial hyperfusion induced by loss of the fission protein Drp1 causes ATM-dependent G2/M arrest and aneuploidy through DNA replication stress. Journal of Cell Science, 125, 5745 57. 
QUINSAY, M. N., THOMAS, R. L., LEE, Y. \& GUSTAFSSON, Å. B. 2010. Bnip3-mediated mitochondrial autophagy is independent of the mitochondrial permeability transition pore. Autophagy, 6, 855862.

QUIRÓS, PEDRO M., ESPAÑOL, Y., ACÍN-PÉREZ, R., RODRÍGUEZ, F., BÁRCENA, C., WATANABE, K., CALVO, E., LOUREIRO, M., FERNÁNDEZ-GARCÍA, M. S., FUEYO, A., VÁZQUEZ, J., ENRÍQUEZ, JOSÉ A. \& LÓPEZ-OTÍN, C. 2014. ATP-Dependent Lon Protease Controls Tumor Bioenergetics by Reprogramming Mitochondrial Activity. Cell Reports, 8, 542-556.

QUIRÓS, P. M., PRADO, M. A., ZAMBONI, N., D'AMICO, D., WILLIAMS, R. W., FINLEY, D., GYGI, S. P. \& AUWERX, J. 2017. Multi-omics analysis identifies ATF4 as a key regulator of the mitochondrial stress response in mammals. Journal of Cell Biology, 216, 2027-2045.

RAINBOLT, T. K., ATANASSOVA, N., GENEREUX, J. C. \& WISEMAN, R. L. 2013. Stress-regulated translational attenuation adapts mitochondrial protein import through Tim17A degradation. Cell Metabolism, 18, 908-919.

RAINBOLT, T. K., LEBEAU, J., PUCHADES, C. \& WISEMAN, R. L. 2016. Reciprocal Degradation of YME1L and OMA1 Adapts Mitochondrial Proteolytic Activity during Stress. Cell Reports, 14, 2041-2049.

RAINBOLT, T. K., SAUNDERS, J. M. \& WISEMAN, R. L. 2015. YME1L degradation reduces mitochondrial proteolytic capacity during oxidative stress. EMBO reports, 16, 97-106.

RAMBOLD, A. S., KOSTELECKY, B., ELIA, N. \& LIPPINCOTT-SCHWARTZ, J. 2011. Tubular network formation protects mitochondria from autophagosomal degradation during nutrient starvation. Proceedings of the National Academy of Sciences, 108, 10190-10195.

RATH, S., SHARMA, R., GUPTA, R., AST, T., CHAN, C., DURHAM, T. J., GOODMAN, R. P., GRABAREK, Z., HAAS, M. E., HUNG, W. H. W., JOSHI, P. R., JOURDAIN, A. A., KIM, S. H., KOTRYS, A. V., LAM, S. S., MCCOY, J. G., MEISEL, J. D., MIRANDA, M., PANDA, A., PATGIRI, A., ROGERS, R., SADRE, S., SHAH, H., SKINNER, O. S., TO, T.-L., WALKER, MELISSA A., WANG, H., WARD, P. S., WENGROD, J., YUAN, C.-C., CALVO, S. E. \& MOOTHA, V. K. 2020. MitoCarta3.0: an updated mitochondrial proteome now with sub-organelle localization and pathway annotations. Nucleic Acids Research, 49, D1541-D1547.

RICHTER, F., DENNERLEIN, S., NIKOLOV, M., JANS, D. C., NAUMENKO, N., AICH, A., MACVICAR, T., LINDEN, A., JAKOBS, S., URLAUB, H., LANGER, T. \& REHLING, P. 2019. ROMO1 is a constituent of the human presequence translocase required for YME1L protease import. Journal of Cell Biology, 218, 598-614.

RIUS-PÉREZ, S., TORRES-CUEVAS, I., MILLÁN, I., ORTEGA, Á. L. \& PÉREZ, S. 2020. PGC-1 $\alpha$, Inflammation, and Oxidative Stress: An Integrative View in Metabolism. Oxidative Medicine and Cellular Longevity, 2020, 1452696.

ROCHA, N., BULGER, D. A., FRONTINI, A., TITHERADGE, H., GRIBSHOLT, S. B., KNOX, R., PAGE, M., HARRIS, J., PAYNE, F., ADAMS, C., SLEIGH, A., CRAWFORD, J., GJESING, A. P., BORK-JENSEN, J., PEDERSEN, O., BARROSO, I., HANSEN, T., COX, H., REILLY, M., ROSSOR, A., BROWN, R. J., TAYLOR, S. I., MCHALE, D., ARMSTRONG, M., ORAL, E. A., SAUDEK, V., O'RAHILLY, S., MAHER, E. R., RICHELSEN, B., SAVAGE, D. B. \& SEMPLE, R. K. 2017. Human biallelic MFN2 mutations induce mitochondrial dysfunction, upper body adipose hyperplasia, and suppression of leptin expression. elife, 6.

ROGOV, V. V., SUZUKI, H., MARINKOVIĆ, M., LANG, V., KATO, R., KAWASAKI, M., BULJUBAŠIĆ, M., ŠPRUNG, M., ROGOVA, N., WAKATSUKI, S., HAMACHER-BRADY, A., DÖTSCH, V., DIKIC, I., BRADY, N. R. \& NOVAK, I. 2017. Phosphorylation of the mitochondrial autophagy receptor Nix enhances its interaction with LC3 proteins. Scientific Reports, 7, 1131.

ROJANSKY, R., CHA, M.-Y. \& CHAN, D. C. 2016. Elimination of paternal mitochondria in mouse embryos occurs through autophagic degradation dependent on PARKIN and MUL1. eLife, 5, e17896. 
RUSTOM, A., SAFFRICH, R., MARKOVIC, I., WALTHER, P. \& GERDES, H.-H. 2004. Nanotubular Highways for Intercellular Organelle Transport. Science, 303, 1007-1010.

RYAN, T. A., PHILLIPS, E. O., COLLIER, C. L., JB ROBINSON, A., ROUTLEDGE, D., WOOD, R. E., ASSAR, E. A. \& TUMBARELLO, D. A. 2020. Tollip coordinates Parkin-dependent trafficking of mitochondrialderived vesicles. The EMBO Journal, 39, e102539.

SABOUNY, R. \& SHUTT, T. E. 2020. Reciprocal Regulation of Mitochondrial Fission and Fusion. Trends in Biochemical Sciences, 45, 564-577.

SAITA, S., NOLTE, H., FIEDLER, K. U., KASHKAR, H., VENNE, A. S., ZAHEDI, R. P., KRÜGER, M. \& LANGER, T. 2017. PARL mediates Smac proteolytic maturation in mitochondria to promote apoptosis. Nature Cell Biology, 19, 318-328.

SANCAK, Y., MARKHARD, A. L., KITAMI, T., KOVÁCS-BOGDÁN, E., KAMER, K. J., UDESHI, N. D., CARR, S. A., CHAUDHURI, D., CLAPHAM, D. E., LI, A. A., CALVO, S. E., GOLDBERGER, O. \& MOOTHA, V. K. 2013. EMRE is an essential component of the mitochondrial calcium uniporter complex. Science, $342,1379-1382$.

SANDOVAL, H., THIAGARAJAN, P., DASGUPTA, S. K., SCHUMACHER, A., PRCHAL, J. T., CHEN, M. \& WANG, J. 2008. Essential role for Nix in autophagic maturation of erythroid cells. Nature, 454, 232-235.

SCHWARTEN, M., MOHRLÜDER, J., MA, P., STOLDT, M., THIELMANN, Y., STANGLER, T., HERSCH, N., HOFFMANN, B., MERKEL, R. \& WILLBOLD, D. 2009. Nix directly binds to GABARAP: A possible crosstalk between apoptosis and autophagy. Autophagy, 5, 690-698.

SCHWARTZ, A. L., TRAUSCH, J. S., CIECHANOVER, A., SLOT, J. W. \& GEUZE, H. 1992. Immunoelectron microscopic localization of the ubiquitin-activating enzyme E1 in HepG2 cells. Proceedings of the National Academy of Sciences, 89, 5542-5546.

SEKINE, S., KANAMARU, Y., KOIKE, M., NISHIHARA, A., OKADA, M., KINOSHITA, H., KAMIYAMA, M., MARUYAMA, J., UCHIYAMA, Y., ISHIHARA, N., TAKEDA, K. \& ICHIJO, H. 2012. Rhomboid protease PARL mediates the mitochondrial membrane potential loss-induced cleavage of PGAM5. Journal of Biological Chemistry, 287, 34635-45.

SEKINE, S., YAO, A., HATTORI, K., SUGAWARA, S., NAGURO, I., KOIKE, M., UCHIYAMA, Y., TAKEDA, K. \& ICHIJO, H. 2016. The Ablation of Mitochondrial Protein Phosphatase Pgam5 Confers Resistance Against Metabolic Stress. EBioMedicine, 5, 82-92.

SEO, J. H., RIVADENEIRA, D. B., CAINO, M. C., CHAE, Y. C., SPEICHER, D. W., TANG, H.-Y., VAIRA, V., BOSARI, S., PALLESCHI, A., RAMPINI, P., KOSSENKOV, A. V., LANGUINO, L. R. \& ALTIERI, D. C. 2016. The Mitochondrial Unfoldase-Peptidase Complex ClpXP Controls Bioenergetics Stress and Metastasis. PLoS Biology, 14, e1002507.

SESAKI, H., SOUTHARD, S. M., YAFFE, M. P. \& JENSEN, R. E. 2003. Mgm1p, a dynamin-related GTPase, is essential for fusion of the mitochondrial outer membrane. Molecular Biology of the Cell, 14, 2342-56.

SHAMSELDIN, H. E., ALSHAMMARI, M., AL-SHEDDI, T., SALIH, M. A., ALKHALIDI, H., KENTAB, A., REPETTO, G. M., HASHEM, M. \& ALKURAYA, F. S. 2012. Genomic analysis of mitochondrial diseases in a consanguineous population reveals novel candidate disease genes. Journal of Medical Genetics, 49, 234-41.

SHAO, L.-W., PENG, Q., DONG, M., GAO, K., LI, Y., LI, Y., LI, C.-Y. \& LIU, Y. 2020. Histone deacetylase HDA1 modulates mitochondrial stress response and longevity. Nature Communications, 11, 4639.

SHAW, J. M. \& NUNNARI, J. 2002. Mitochondrial dynamics and division in budding yeast. Trends in cell biology, 12, 178-184.

SHEN, P. S., PARK, J., QIN, Y., LI, X., PARSAWAR, K., LARSON, M. H., COX, J., CHENG, Y., LAMBOWITZ, A. M., WEISSMAN, J. S., BRANDMAN, O. \& FROST, A. 2015. Rqc2p and $60 S$ ribosomal subunits mediate mRNA-independent elongation of nascent chains. Science, 347, 75-78. 
SHEN, Z., LI, Y., GASPARSKI, A. N., ABELIOVICH, H. \& GREENBERG, M. L. 2017. Cardiolipin Regulates Mitophagy through the Protein Kinase C Pathway. Journal of Biological Chemistry, 292, 29162923.

SHIBA-FUKUSHIMA, K., ARANO, T., MATSUMOTO, G., INOSHITA, T., YOSHIDA, S., ISHIHAMA, Y., RYU, K. Y., NUKINA, N., HATTORI, N. \& IMAI, Y. 2014. Phosphorylation of mitochondrial polyubiquitin by PINK1 promotes Parkin mitochondrial tethering. PLoS Genet, 10, e1004861.

SHIN, J.-H., KO, HAN S., KANG, H., LEE, Y., LEE, Y.-I., PLETINKOVA, O., TROCONSO, JUAN C., DAWSON, VALINA L. \& DAWSON, TED M. 2011. PARIS (ZNF746) Repression of PGC-1 $\alpha$ Contributes to Neurodegeneration in Parkinson's Disease. Cell, 144, 689-702.

SHITARA, H., KANEDA, H., SATO, A., INOUE, K., OGURA, A., YONEKAWA, H. \& HAYASHI, J. I. 2000. Selective and continuous elimination of mitochondria microinjected into mouse eggs from spermatids, but not from liver cells, occurs throughout embryogenesis. Genetics, 156, 1277-84.

SHPILKA, T. \& HAYNES, C. M. 2018. The mitochondrial UPR: mechanisms, physiological functions and implications in ageing. Nature Reviews Molecular Cell Biology, 19, 109-120.

SLITER, D. A., MARTINEZ, J., HAO, L., CHEN, X., SUN, N., FISCHER, T. D., BURMAN, J. L., LI, Y., ZHANG, Z., NARENDRA, D. P., CAI, H., BORSCHE, M., KLEIN, C. \& YOULE, R. J. 2018. Parkin and PINK1 mitigate STING-induced inflammation. Nature, 561, 258-262.

SMIRNOVA, E., GRIPARIC, L., SHURLAND, D. L. \& VAN DER BLIEK, A. M. 2001. Dynamin-related protein Drp1 is required for mitochondrial division in mammalian cells. Molecular Biology of the Cell, 12, 2245-2256.

SONG, Z., CHEN, H., FIKET, M., ALEXANDER, C. \& CHAN, D. C. 2007. OPA1 processing controls mitochondrial fusion and is regulated by mRNA splicing, membrane potential, and Yme1L. Journal of Cell Biology, 178, 749-55.

SOUBANNIER, V., MCLELLAND, G. L., ZUNINO, R., BRASCHI, E., RIPPSTEIN, P., FON, E. A. \& MCBRIDE, H. M. 2012a. A vesicular transport pathway shuttles cargo from mitochondria to lysosomes. Current Biology, 22, 135-41.

SOUBANNIER, V., RIPPSTEIN, P., KAUFMAN, B. A., SHOUBRIDGE, E. A. \& MCBRIDE, H. M. 2012b. Reconstitution of mitochondria derived vesicle formation demonstrates selective enrichment of oxidized cargo. PLoS One, 7, e52830-e52830.

SPINAZZI, M., RADAELLI, E., HORRÉ, K., ARRANZ, A. M., GOUNKO, N. V., AGOSTINIS, P., MAIA, T. M., IMPENS, F., MORAIS, V. A., LOPEZ-LLUCH, G., SERNEELS, L., NAVAS, P. \& DE STROOPER, B. 2019. PARL deficiency in mouse causes Complex III defects, coenzyme $Q$ depletion, and Leigh-like syndrome. Proceedings of the National Academy of Sciences, 116, 277-286.

SPINELLI, J. B. \& HAIGIS, M. C. 2018. The multifaceted contributions of mitochondria to cellular metabolism. Nature Cell Biology, 20, 745-754.

SPRENGER, H. G., WANI, G., HESSELING, A., KÖNIG, T., PATRON, M., MACVICAR, T., AHOLA, S., WAI, T., BARTH, E., RUGARLI, E. I., BERGAMI, M. \& LANGER, T. 2019. Loss of the mitochondrial i-AAA protease YME1L leads to ocular dysfunction and spinal axonopathy. EMBO Molecular Medicine, 11.

SU, T., IZAWA, T., THOMS, M., YAMASHITA, Y., CHENG, J., BERNINGHAUSEN, O., HARTL, F. U., INADA, T., NEUPERT, W. \& BECKMANN, R. 2019. Structure and function of Vms1 and Arb1 in RQC and mitochondrial proteome homeostasis. Nature, 570, 538-542.

SUGIURA, A., MCLELLAND, G.-L., FON, E. A. \& MCBRIDE, H. M. 2014. A new pathway for mitochondrial quality control: mitochondrial-derived vesicles. The EMBO Journal, 33, 2142-2156.

SUGIURA, A., NAGASHIMA, S., TOKUYAMA, T., AMO, T., MATSUKI, Y., ISHIDO, S., KUDO, Y., MCBRIDE, H. M., FUKUDA, T., MATSUSHITA, N., INATOME, R. \& YANAGI, S. 2013. MITOL regulates endoplasmic reticulum-mitochondria contacts via Mitofusin2. Molecular Cell, 51, 20-34. 
SUGIURA, A., YONASHIRO, R., FUKUDA, T., MATSUSHITA, N., NAGASHIMA, S., INATOME, R. \& YANAGI, S. 2011. A mitochondrial ubiquitin ligase MITOL controls cell toxicity of polyglutamine-expanded protein. Mitochondrion, 11, 139-46.

SUNDARESAN, N. R., GUPTA, M., KIM, G., RAJAMOHAN, S. B., ISBATAN, A. \& GUPTA, M. P. 2009. Sirt3 blocks the cardiac hypertrophic response by augmenting Foxo3a-dependent antioxidant defense mechanisms in mice. J Clin Invest, 119, 2758-71.

SZCZEPANOWSKA, K., MAITI, P., KUKAT, A., HOFSETZ, E., NOLTE, H., SENFT, K., BECKER, C., RUZZENENTE, B., HORNIG-DO, H.-T., WIBOM, R., WIESNER, R. J., KRÜGER, M. \& TRIFUNOVIC, A. 2016. CLPP coordinates mitoribosomal assembly through the regulation of ERAL1 levels. The EMBO Journal, 35, 2566-2583.

SZCZEPANOWSKA, K., SENFT, K., HEIDLER, J., HERHOLZ, M., KUKAT, A., HÖHNE, M. N., HOFSETZ, E., BECKER, C., KASPAR, S., GIESE, H., ZWICKER, K., GUERRERO-CASTILLO, S., BAUMANN, L., KAUPPILA, J., RUMYANTSEVA, A., MÜLLER, S., FRESE, C. K., BRANDT, U., RIEMER, J., WITTIG, I. \& TRIFUNOVIC, A. 2020. A salvage pathway maintains highly functional respiratory complex I. Nature Communications, 11, 1643.

TAKANO-OHMURO, H., MUKAIDA, M., KOMINAMI, E. \& MORIOKA, K. 2000. Autophagy in embryonic erythroid cells: its role in maturation. European Journal of Cell Biology, 79, 759-64.

TANAKA, A., CLELAND, M. M., XU, S., NARENDRA, D. P., SUEN, D.-F., KARBOWSKI, M. \& YOULE, R. J. 2010. Proteasome and $p 97$ mediate mitophagy and degradation of mitofusins induced by Parkin. Journal of Cell Biology, 191, 1367-1380.

TESKE, B. F., FUSAKIO, M. E., ZHOU, D., SHAN, J., MCCLINTICK, J. N., KILBERG, M. S. \& WEK, R. C. 2013. $\mathrm{CHOP}$ induces activating transcription factor 5 (ATF5) to trigger apoptosis in response to perturbations in protein homeostasis. Molecular Biology of the Cell, 24, 2477-90.

TIEU, Q., OKREGLAK, V., NAYLOR, K. \& NUNNARI, J. 2002. The WD repeat protein, Mdv1p, functions as a molecular adaptor by interacting with Dnm1p and Fis1p during mitochondrial fission. Journal of Cell Biology, 158, 445-452.

TONDERA, D., CZAUDERNA, F., PAULICK, K., SCHWARZER, R., KAUFMANN, J. \& SANTEL, A. 2005. The mitochondrial protein MTP18 contributes to mitochondrial fission in mammalian cells. Journal of Cell Science, 118, 3049-3059.

TONDERA, D., GRANDEMANGE, S., JOURDAIN, A., KARBOWSKI, M., MATTENBERGER, Y., HERZIG, S., DA CRUZ, S., CLERC, P., RASCHKE, I., MERKWIRTH, C., EHSES, S., KRAUSE, F., CHAN, D. C., ALEXANDER, C., BAUER, C., YOULE, R., LANGER, T. \& MARTINOU, J.-C. 2009. SLP-2 is required for stress-induced mitochondrial hyperfusion. The EMBO Journal, 28, 1589-1600.

TONDERA, D., SANTEL, A., SCHWARZER, R., DAMES, S., GIESE, K., KLIPPEL, A. \& KAUFMANN, J. 2004. Knockdown of MTP18, a novel phosphatidylinositol 3-kinase-dependent protein, affects mitochondrial morphology and induces apoptosis. Journal of Biological Chemistry, 279, 3154455.

TOYAMA, E. Q., HERZIG, S., COURCHET, J., LEWIS, T. L., JR., LOSÓN, O. C., HELLBERG, K., YOUNG, N. P., CHEN, H., POLLEUX, F., CHAN, D. C. \& SHAW, R. J. 2016. Metabolism. AMP-activated protein kinase mediates mitochondrial fission in response to energy stress. Science, 351, 275-281.

TRACY, K., DIBLING, B. C., SPIKE, B. T., KNABB, J. R., SCHUMACKER, P. \& MACLEOD, K. F. 2007. BNIP3 IS an RB/E2F Target Gene Required for Hypoxia-Induced Autophagy. Molecular and Cellular Biology, 27, 6229-6242.

TWIG, G., ELORZA, A., MOLINA, A. J. A., MOHAMED, H., WIKSTROM, J. D., WALZER, G., STILES, L., HAIGH, S. E., KATZ, S., LAS, G., ALROY, J., WU, M., PY, B. F., YUAN, J., DEENEY, J. T., CORKEY, B. E. \& SHIRIHAI, O. S. 2008. Fission and selective fusion govern mitochondrial segregation and elimination by autophagy. The EMBO Journal, 27, 433-446. 
VAFAI, S. B. \& MOOTHA, V. K. 2012. Mitochondrial disorders as windows into an ancient organelle. Nature, 491, 374-83.

VALENTE, E. M., ABOU-SLEIMAN, P. M., CAPUTO, V., MUQIT, M. M., HARVEY, K., GISPERT, S., ALI, Z., DEL TURCO, D., BENTIVOGLIO, A. R., HEALY, D. G., ALBANESE, A., NUSSBAUM, R., GONZÁLEZMALDONADO, R., DELLER, T., SALVI, S., CORTELLI, P., GILKS, W. P., LATCHMAN, D. S., HARVEY, R. J., DALLAPICCOLA, B., AUBURGER, G. \& WOOD, N. W. 2004. Hereditary early-onset Parkinson's disease caused by mutations in PINK1. Science, 304, 1158-60.

VAN HAAFTEN-VISSER, D. Y., HARAKALOVA, M., MOCHOLI, E., VAN MONTFRANS, J. M., ELKADRI, A., RIETER, E., FIEDLER, K., VAN HASSELT, P. M., TRIFFAUX, E. M. M., VAN HAELST, M. M., NIJMAN, I. J., KLOOSTERMAN, W. P., NIEUWENHUIS, E. E. S., MUISE, A. M., CUPPEN, E., HOUWEN, R. H. J. \& COFFER, P. J. 2017. Ankyrin repeat and zinc-finger domain-containing 1 mutations are associated with infantile-onset inflammatory bowel disease. Journal of Biological Chemistry, 292, 79047920.

VARGAS, J. N. S., WANG, C., BUNKER, E., HAO, L., MARIC, D., SCHIAVO, G., RANDOW, F. \& YOULE, R. J. 2019. Spatiotemporal Control of ULK1 Activation by NDP52 and TBK1 during Selective Autophagy. Molecular Cell, 74, 347-362.e6.

VERMA, R., OANIA, R. S., KOLAWA, N. J. \& DESHAIES, R. J. 2013. Cdc48/p97 promotes degradation of aberrant nascent polypeptides bound to the ribosome. eLife, 2, e00308.

VERMA, R., REICHERMEIER, K. M., BURROUGHS, A. M., OANIA, R. S., REITSMA, J. M., ARAVIND, L. \& DESHAIES, R. J. 2018. Vms1 and ANKZF1 peptidyl-tRNA hydrolases release nascent chains from stalled ribosomes. Nature, 557, 446-451.

VILLA, E., PROÏCS, E., RUBIO-PATIÑO, C., OBBA, S., ZUNINO, B., BOSSOWSKI, J. P., ROZIER, R. M., CHICHE, J., MONDRAGÓN, L., RILEY, J. S., MARCHETTI, S., VERHOEYEN, E., TAIT, S. W. G. \& RICCI, J.-E. 2017. Parkin-Independent Mitophagy Controls Chemotherapeutic Response in Cancer Cells. Cell Reports, 20, 2846-2859.

VUKOTIC, M., NOLTE, H., KÖNIG, T., SAITA, S., ANANJEW, M., KRÜGER, M., TATSUTA, T. \& LANGER, T. 2017. Acylglycerol Kinase Mutated in Sengers Syndrome Is a Subunit of the TIM22 Protein Translocase in Mitochondria. Molecular Cell, 67, 471-483.e7.

VÖGTLE, F. N., BURKHART, J. M., GONCZAROWSKA-JORGE, H., KÜCÜKKÖSE, C., TASKIN, A. A., KOPCZYNSKI, D., AHRENDS, R., MOSSMANN, D., SICKMANN, A., ZAHEDI, R. P. \& MEISINGER, C. 2017. Landscape of submitochondrial protein distribution. Nature Communications, 8, 290.

WAI, T., GARCÍA-PRIETO, J., BAKER, M. J., MERKWIRTH, C., BENIT, P., RUSTIN, P., RUPÉREZ, F. J., BARBAS, C., IBAÑEZ, B. \& LANGER, T. 2015. Imbalanced OPA1 processing and mitochondrial fragmentation cause heart failure in mice. Science, 350, aad0116.

WAI, T. \& LANGER, T. 2013. Chapter 146 - The i-AAA Protease. In: RAWLINGS, N. D. \& SALVESEN, G. (eds.) Handbook of Proteolytic Enzymes (Third Edition). Academic Press.

WAI, T., SAITA, S., NOLTE, H., MÜLLER, S., KÖNIG, T., RICHTER-DENNERLEIN, R., SPRENGER, H. G., MADRENAS, J., MÜHLMEISTER, M., BRANDT, U., KRÜGER, M. \& LANGER, T. 2016. The membrane scaffold SLP2 anchors a proteolytic hub in mitochondria containing PARL and the i-AAA protease YME1L. EMBO reports, 17, 1844-1856.

WANG, K., JIN, M., LIU, X. \& KLIONSKY, D. J. 2013. Proteolytic processing of Atg32 by the mitochondrial iAAA protease $Y m e 1$ regulates mitophagy. Autophagy, 9, 1828-36.

WANG, L., MYASNIKOV, A., PAN, X. \& WALTER, P. 2020. Structure of the AAA protein Msp1 reveals mechanism of mislocalized membrane protein extraction. eLife, 9, e54031.

WANG, X. \& CHEN, X. J. 2015. A cytosolic network suppressing mitochondria-mediated proteostatic stress and cell death. Nature, 524, 481-484.

WANG, X. \& GERDES, H. H. 2015. Transfer of mitochondria via tunneling nanotubes rescues apoptotic PC12 cells. Cell Death and Differentiation, 22, 1181-91. 
WANG, Z., JIANG, H., CHEN, S., DU, F. \& WANG, X. 2012. The mitochondrial phosphatase PGAM5 functions at the convergence point of multiple necrotic death pathways. Cell, 148, 228-43.

WATERHAM, H. R., KOSTER, J., VAN ROERMUND, C. W., MOOYER, P. A., WANDERS, R. J. \& LEONARD, J. V. 2007. A lethal defect of mitochondrial and peroxisomal fission. New England Journal of Medicine, 356, 1736-41.

WAUER, T., SIMICEK, M., SCHUBERT, A. \& KOMANDER, D. 2015. Mechanism of phospho-ubiquitininduced PARKIN activation. Nature, 524, 370-374.

WEI, Y., CHIANG, W. C., SUMPTER, R., JR., MISHRA, P. \& LEVINE, B. 2017. Prohibitin 2 Is an Inner Mitochondrial Membrane Mitophagy Receptor. Cell, 168, 224-238.e10.

WEIDBERG, H. \& AMON, A. 2018. MitoCPR-A surveillance pathway that protects mitochondria in response to protein import stress. Science, 360, eaan4146.

WIEDEMANN, N. \& PFANNER, N. 2017. Mitochondrial Machineries for Protein Import and Assembly. Annual Review of Biochemistry, 86, 685-714.

WOLF, D. M., SEGAWA, M., KONDADI, A. K., ANAND, R., BAILEY, S. T., REICHERT, A. S., VAN DER BLIEK, A. M., SHACKELFORD, D. B., LIESA, M. \& SHIRIHAI, O. S. 2019. Individual cristae within the same mitochondrion display different membrane potentials and are functionally independent. The EMBO Journal, 38, e101056.

WONG, Y. C. \& HOLZBAUR, E. L. 2014. Optineurin is an autophagy receptor for damaged mitochondria in parkin-mediated mitophagy that is disrupted by an ALS-linked mutation. Proceedings of the National Academy of Sciences, 111, E4439-48.

WONG, Y. C., YSSELSTEIN, D. \& KRAINC, D. 2018. Mitochondria-lysosome contacts regulate mitochondrial fission via RAB7 GTP hydrolysis. Nature, 554, 382-386.

WROBEL, L., TOPF, U., BRAGOSZEWSKI, P., WIESE, S., SZTOLSZTENER, M. E., OELJEKLAUS, S., VARABYOVA, A., LIRSKI, M., CHROSCICKI, P., MROCZEK, S., JANUSZEWICZ, E., DZIEMBOWSKI, A., KOBLOWSKA, M., WARSCHEID, B. \& CHACINSKA, A. 2015. Mistargeted mitochondrial proteins activate a proteostatic response in the cytosol. Nature, 524, 485-8.

WU, W., LIN, C., WU, K., JIANG, L., WANG, X., LI, W., ZHUANG, H., ZHANG, X., CHEN, H., LI, S., YANG, Y., LU, Y., WANG, J., ZHU, R., ZHANG, L., SUI, S., TAN, N., ZHAO, B., ZHANG, J., LI, L. \& FENG, D. 2016a. FUNDC1 regulates mitochondrial dynamics at the ER-mitochondrial contact site under hypoxic conditions. The EMBO Journal, 35, 1368-1384.

WU, W., TIAN, W., HU, Z., CHEN, G., HUANG, L., LI, W., ZHANG, X., XUE, P., ZHOU, C., LIU, L., ZHU, Y., ZHANG, X., LI, L., ZHANG, L., SUI, S., ZHAO, B. \& FENG, D. 2014. ULK1 translocates to mitochondria and phosphorylates FUNDC1 to regulate mitophagy. EMBO reports, 15, 566-575.

WU, X., LI, L. \& JIANG, H. 2016b. Doa1 targets ubiquitinated substrates for mitochondria-associated degradation. Journal of Cell Biology, 213, 49-63.

WU, Z., TANTRAY, I., LIM, J., CHEN, S., LI, Y., DAVIS, Z., SITRON, C., DONG, J., GISPERT, S., AUBURGER, G., BRANDMAN, O., BI, X., SNYDER, M. \& LU, B. 2019. MISTERMINATE Mechanistically Links Mitochondrial Dysfunction with Proteostasis Failure. Molecular Cell, 75, 835-848.e8.

WU, Z., WANG, Y., LIM, J., LIU, B., LI, Y., VARTAK, R., STANKIEWICZ, T., MONTGOMERY, S. \& LU, B. 2018. Ubiquitination of ABCE1 by NOT4 in Response to Mitochondrial Damage Links Co-translational Quality Control to PINK1-Directed Mitophagy. Cell Metabolism, 28, 130-144.e7.

XIAO, X., HU, Y., QUIRÓS, P. M., WEI, Q., LÓPEZ-OTÍN, C. \& DONG, Z. 2014. OMA1 mediates OPA1 proteolysis and mitochondrial fragmentation in experimental models of ischemic kidney injury. American Journal of Physiology - Renal Physiology, 306, F1318-26.

XU, S., PENG, G., WANG, Y., FANG, S. \& KARBOWSKI, M. 2011. The AAA-ATPase $p 97$ is essential for outer mitochondrial membrane protein turnover. Molecular Biology of the Cell, 22, 291-300.

YAMADA, T., MURATA, D., ADACHI, Y., ITOH, K., KAMEOKA, S., IGARASHI, A., KATO, T., ARAKI, Y., HUGANIR, R. L., DAWSON, T. M., YANAGAWA, T., OKAMOTO, K., IIJIMA, M. \& SESAKI, H. 2018. 
Mitochondrial Stasis Reveals p62-Mediated Ubiquitination in Parkin-Independent Mitophagy and Mitigates Nonalcoholic Fatty Liver Disease. Cell Metabolism, 28, 588-604.e5.

YAMANO, K., KIKUCHI, R., KOJIMA, W., HAYASHIDA, R., KOYANO, F., KAWAWAKI, J., SHODA, T., DEMIZU, Y., NAITO, M., TANAKA, K. \& MATSUDA, N. 2020. Critical role of mitochondrial ubiquitination and the OPTN-ATG9A axis in mitophagy. Journal of Cell Biology, 219.

YAMANO, K. \& YOULE, R. J. 2013. PINK1 is degraded through the N-end rule pathway. Autophagy, 9, 1758-1769.

YAMASHITA, S.-I., JIN, X., FURUKAWA, K., HAMASAKI, M., NEZU, A., OTERA, H., SAIGUSA, T., YOSHIMORI, T., SAKAI, Y., MIHARA, K. \& KANKI, T. 2016. Mitochondrial division occurs concurrently with autophagosome formation but independently of Drp1 during mitophagy. Journal of Cell Biology, 215, 649-665.

YAMASHITA, S. I. \& KANKI, T. 2017. How autophagy eats large mitochondria: Autophagosome formation coupled with mitochondrial fragmentation. Autophagy, 13, 980-981.

YAN, J., LIU, X.-H., HAN, M.-Z., WANG, Y.-M., SUN, X.-L., YU, N., LI, T., SU, B. \& CHEN, Z.-Y. 2015. Blockage of GSK3 $\beta$-mediated Drp1 phosphorylation provides neuroprotection in neuronal and mouse models of Alzheimer's disease. Neurobiology of Aging, 36, 211-227.

YANG, J.-Y. \& YANG, W. Y. 2013. Bit-by-bit autophagic removal of parkin-labelled mitochondria. Nature Communications, 4, 2428.

YANG, L., NA, C. L., LUO, S., WU, D., HOGAN, S., HUANG, T. \& WEAVER, T. E. 2017. The Phosphatidylcholine Transfer Protein Stard7 is Required for Mitochondrial and Epithelial Cell Homeostasis. Scientific Reports, 7, 46416.

YAO, P. J., EREN, E., PETRALIA, R. S., GU, J. W., WANG, Y.-X. \& KAPOGIANNIS, D. 2020. Mitochondrial Protrusions in Neuronal Cells. iScience, 23, 101514.

YE, X., SUN, X., STAROVOYTOV, V. \& CAI, Q. 2015. Parkin-mediated mitophagy in mutant hAPP neurons and Alzheimer's disease patient brains. Human Molecular Genetics, 24, 2938-51.

YIEN, Y. Y., DUCAMP, S., VAN DER VORM, L. N., KARDON, J. R., MANCEAU, H., KANNENGIESSER, C., BERGONIA, H. A., KAFINA, M. D., KARIM, Z., GOUYA, L., BAKER, T. A., PUY, H., PHILLIPS, J. D., NICOLAS, G. \& PAW, B. H. 2017. Mutation in human CLPX elevates levels of $\delta$-aminolevulinate synthase and protoporphyrin IX to promote erythropoietic protoporphyria. Proceedings of the National Academy of Sciences, 114, E8045-E8052.

YIP, M. C. J., KESZEI, A. F. A., FENG, Q., CHU, V., MCKENNA, M. J. \& SHAO, S. 2019. Mechanism for recycling tRNAs on stalled ribosomes. Nature Structural \& Molecular Biology, 26, 343-349.

YLÄ-ANTTILA, P., VIHINEN, H., JOKITALO, E. \& ESKELINEN, E. L. 2009. 3D tomography reveals connections between the phagophore and endoplasmic reticulum. Autophagy, 5, 1180-5.

YONASHIRO, R., SUGIURA, A., MIYACHI, M., FUKUDA, T., MATSUSHITA, N., INATOME, R., OGATA, Y., SUZUKI, T., DOHMAE, N. \& YANAGI, S. 2009. Mitochondrial ubiquitin ligase MITOL ubiquitinates mutant SOD1 and attenuates mutant SOD1-induced reactive oxygen species generation. Molecular Biology of the Cell, 20, 4524-30.

YOSHII, S. R., KISHI, C., ISHIHARA, N. \& MIZUSHIMA, N. 2011. Parkin mediates proteasome-dependent protein degradation and rupture of the outer mitochondrial membrane. Journal of Biological Chemistry, 286, 19630-40.

YU, R., JIN, S. B., LENDAHL, U., NISTÉR, M. \& ZHAO, J. 2019. Human Fis1 regulates mitochondrial dynamics through inhibition of the fusion machinery. The EMBO Journal, 38.

YUN, J., PURI, R., YANG, H., LIZZIO, M. A., WU, C., SHENG, Z. H. \& GUO, M. 2014. MUL1 acts in parallel to the PINK1/parkin pathway in regulating mitofusin and compensates for loss of PINK1/parkin. elife, 3, e01958.

ZACHARI, M., GUDMUNDSSON, S. R., LI, Z., MANIFAVA, M., SHAH, R., SMITH, M., STRONGE, J., KARANASIOS, E., PIUNTI, C., KISHI-ITAKURA, C., VIHINEN, H., JOKITALO, E., GUAN, J. L., BUSS, F., 
SMITH, A. M., WALKER, S. A., ESKELINEN, E. L. \& KTISTAKIS, N. T. 2019. Selective Autophagy of Mitochondria on a Ubiquitin-Endoplasmic-Reticulum Platform. Developmental Cell, 50, 627643.e5.

ZHONG, Z., UMEMURA, A., SANCHEZ-LOPEZ, E., LIANG, S., SHALAPOUR, S., WONG, J., HE, F., BOASSA, D., PERKINS, G., ALI, S. R., MCGEOUGH, M. D., ELLISMAN, M. H., SEKI, E., GUSTAFSSON, A. B., HOFFMAN, H. M., DIAZ-MECO, M. T., MOSCAT, J. \& KARIN, M. 2016. NF-KB Restricts Inflammasome Activation via Elimination of Damaged Mitochondria. Cell, 164, 896-910.

ZHOU, D., PALAM, L. R., JIANG, L., NARASIMHAN, J., STASCHKE, K. A. \& WEK, R. C. 2008. Phosphorylation of elF2 directs ATF5 translational control in response to diverse stress conditions. Journal of Biological Chemistry, 283, 7064-73.

ZHOU, W., CHEN, K. H., CAO, W., ZENG, J., LIAO, H., ZHAO, L. \& GUO, X. 2010. Mutation of the protein kinase $\mathrm{A}$ phosphorylation site influences the anti-proliferative activity of mitofusin 2. Atherosclerosis, 211, 216-23.

ZHU, Y., MASSEN, S., TERENZIO, M., LANG, V., CHEN-LINDNER, S., EILS, R., NOVAK, I., DIKIC, I., HAMACHER-BRADY, A. \& BRADY, N. R. 2013. Modulation of serines 17 and 24 in the LC3interacting region of Bnip3 determines pro-survival mitophagy versus apoptosis. Journal of Biological Chemistry, 288, 1099-113.

ZURITA RENDÓN, O., FREDRICKSON, E. K., HOWARD, C. J., VAN VRANKEN, J., FOGARTY, S., TOLLEY, N. D., KALIA, R., OSUNA, B. A., SHEN, P. S., HILL, C. P., FROST, A. \& RUTTER, J. 2018. Vms1p is a release factor for the ribosome-associated quality control complex. Nature Communications, 9, 2197.

ZURITA RENDÓN, O. \& SHOUBRIDGE, E. A. 2018. LONP1 Is Required for Maturation of a Subset of Mitochondrial Proteins, and Its Loss Elicits an Integrated Stress Response. Molecular and Cellular Biology, 38.

ZÜCHNER, S., MERSIYANOVA, I. V., MUGLIA, M., BISSAR-TADMOURI, N., ROCHELLE, J., DADALI, E. L., ZAPPIA, M., NELIS, E., PATITUCCI, A., SENDEREK, J., PARMAN, Y., EVGRAFOV, O., JONGHE, P. D., TAKAHASHI, Y., TSUJI, S., PERICAK-VANCE, M. A., QUATTRONE, A., BATTOLOGLU, E., POLYAKOV, A. V., TIMMERMAN, V., SCHRÖDER, J. M. \& VANCE, J. M. 2004. Mutations in the mitochondrial GTPase mitofusin 2 cause Charcot-Marie-Tooth neuropathy type 2A. Nature Genetics, 36, 449451. 


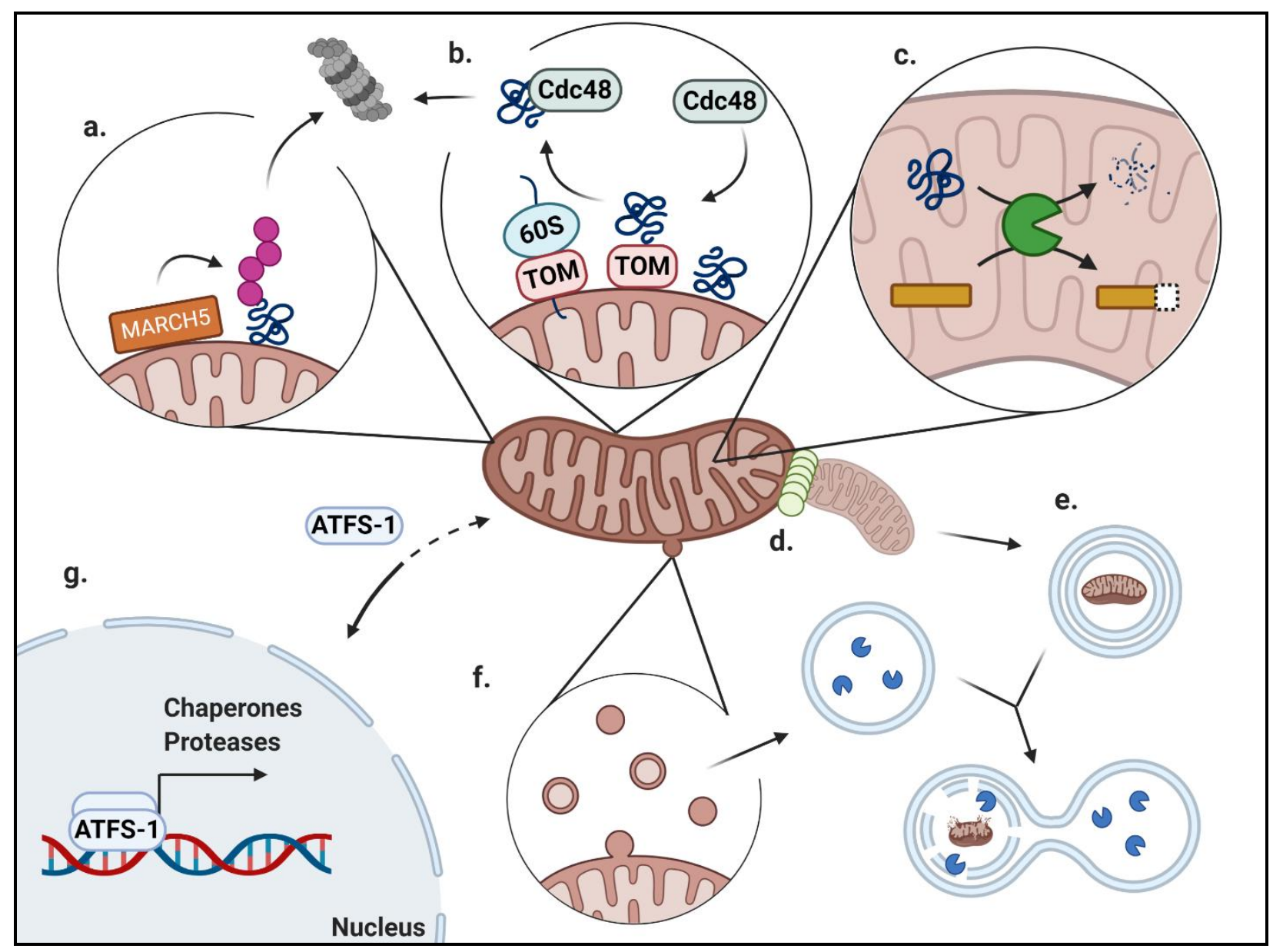

Figure 1: Organellar and protein quality control mechanisms of mitochondria. a. The Ubiquitin Proteasome System (UPS): mitochondrial proteins are conjugated with polyubiquitin chains (in purple) by E3 ubiquitin ligases like MARCH5 and are targeted for degradation by the proteasome. $\mathbf{b}$. Precursor-associated degradation involves the removal of aberrant proteins synthesized on cytosolic ribosomes (60s) on the OMM and on mitochondrial translocases with/without the assistance of the AAA+ ATPase Cdc48. c. Mitochondrial proteases carry out both quality control and regulatory functions. d. Mitochondrial morphology is regulated by fission and fusion events (green circles). e. Mitophagy: mitochondrial fragments destined for degradation are first engulfed in autophagosomes that eventually fuse with lysosomes. $f$. Mitochondrial-derived vesicles (MDVs) are small vesicles formed from the OMM and at times IMM, and contain select mitochondrial proteins that are destined for the peroxisomes or lysosomes. g. The Unfolded Protein Response of the mitochondria (UPRmt) induces chaperone and protease gene expression in response to mitochondrial stress through activation of transcription factors such as ATFS- 1 . 


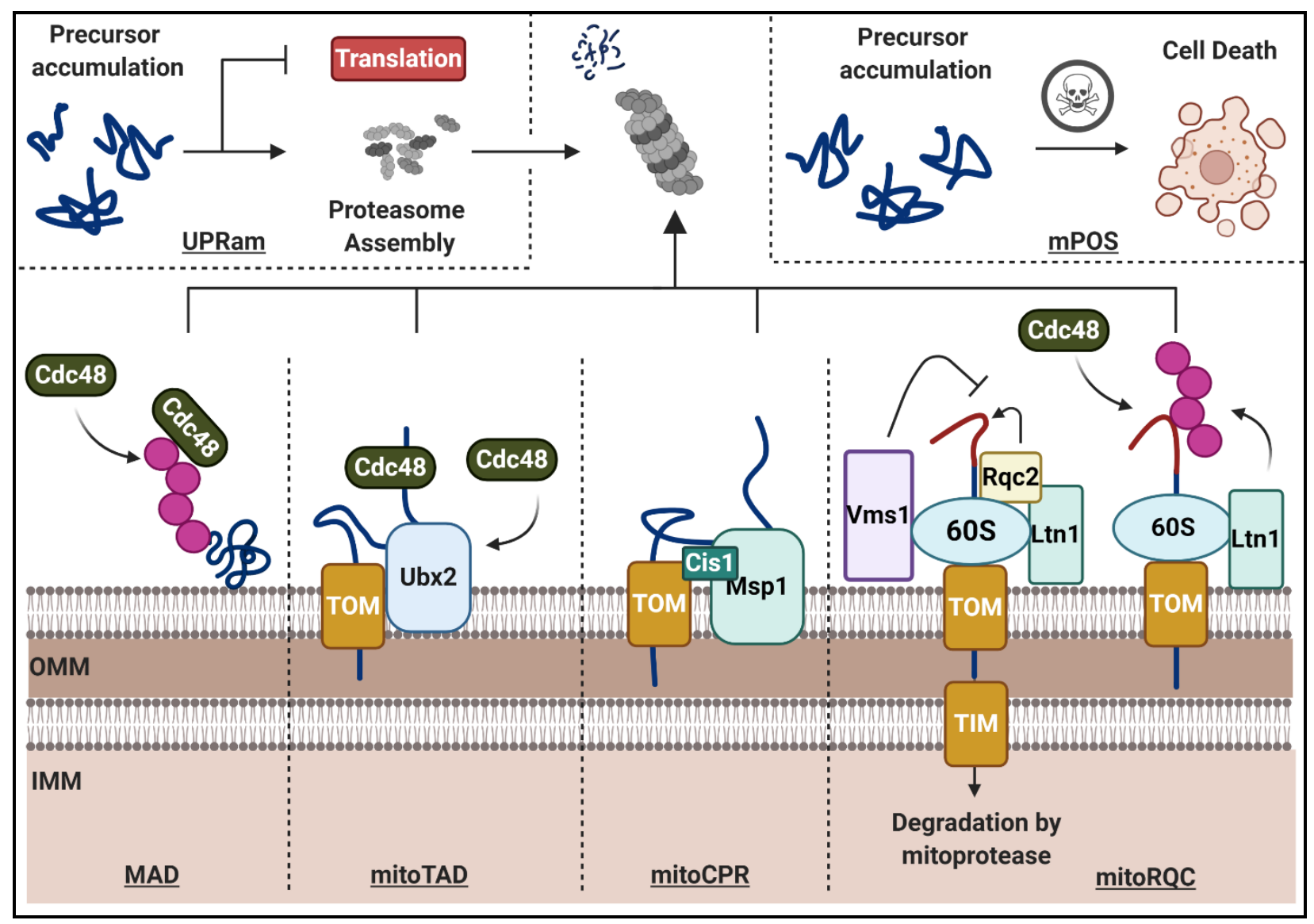

Figure 2: Extramitochondrial protein quality control. Mitochondria associated degradation (MAD): Aggregates on the OMM are ubiquitinated, removed and delivered by $\mathrm{Cdc} 48$ to the proteasome for degradation. Mitochondrial protein translocationassociated degradation (mitoTAD): Ubx2 recruits Cdc48 to assist in the removal of stalled peptides in the TOM complex for degradation by the proteasome. Mitochondrial compromised protein import response (mitoCPR): Cis1 bridges the TOM complex and Msp1, which facilitates the extraction of stalled peptides for degradation at the proteasome. Mitochondria ribosomal quality control (mitoRQC): In the Vms1 arm (left), Vms1 inhibits Rqc2 mediated CAT-tailing at the 60s ribosome, to allow transport of the peptide into the matrix where it is degraded by mitoproteases. In the Ltn1 arm (right), the CAT-tailed peptide (in red) is ubiquitinated, which promotes its extraction by Cdc48 to be degraded by the proteasome. Unfolded protein response activated by mistargeting of proteins (UPRam): Accumulation of unimported precursors in the cytosol induces proteasome assembly and suppress cytosolic translation. Mitochondria precursor overaccumulation stress (mPOS): The accumulation of toxic precursors in the cytosol triggers cell death. 


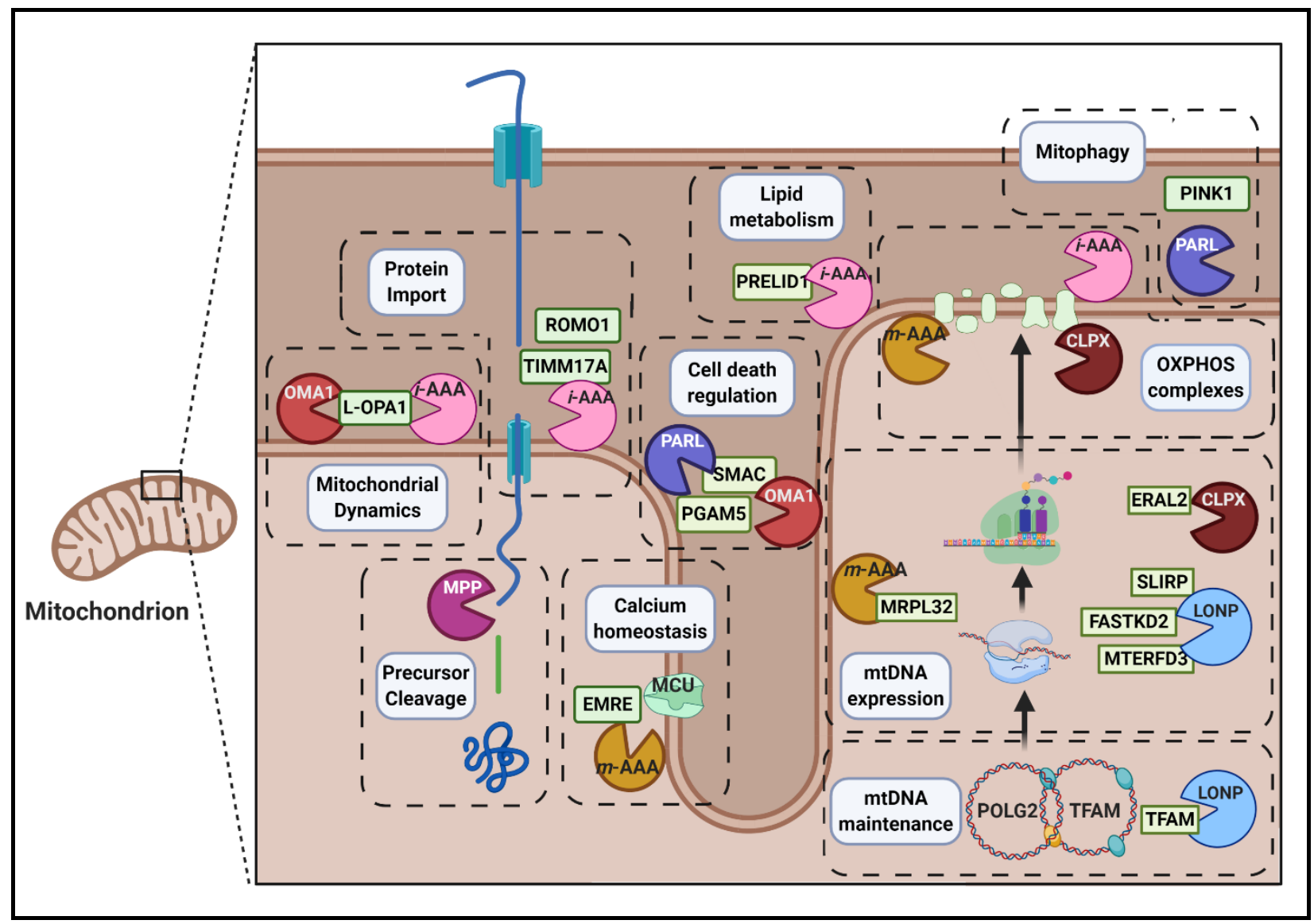

Figure 3: Mitochondrial proteases. Proteins in green boxes represent mitoprotease substrates. Protein import: Translocase proteins, such as TIMM17A and ROMO1, are substrates for YME1L-mediated turnover. Mitochondrial dynamics: YME1L and OMA1 regulate fission/fusion through the processing of L-OPA1. Precursor cleavage: MPP removes the pre-sequence from most precursors. Cell death regulation: Proteolytic processing of SMAC by PARL and PGAM5 by OMA1 promotes apoptosis and necroptosis, respectively. Lipid metabolism: YME1L regulates the turnover of the phosphatidic acid transport protein PRELID1. Calcium homeostasis: m-AAA protease degrades EMRE which otherwise assembles with MCU to form an active $\mathrm{Ca}^{2+}$ channel. Mitophagy: PARL cleaves the mitophagy related PINK1 kinase under normal conditions to stimulate its retro- translocation and subsequent proteasomal degradation. OXPHOS complexes: Components of the OXPHOS machinery are substrates for proteolytic turnover by CLPX, i-AAA and m-AAA. mtDNA expression: LONP regulates the maturation of mitochondria translation associated proteins (SLIRP, MRPL32 and FASTKD2), while the m-AAA mediated processing of MRPL32 promotes mitoribosome assembly, and CLPX degrades the negative regulator of mitoribosome assembly EARL2. $\boldsymbol{m t D N A}$ maintenance: LONP regulates turnover of the mtDNA nucleoid protein TFAM. 


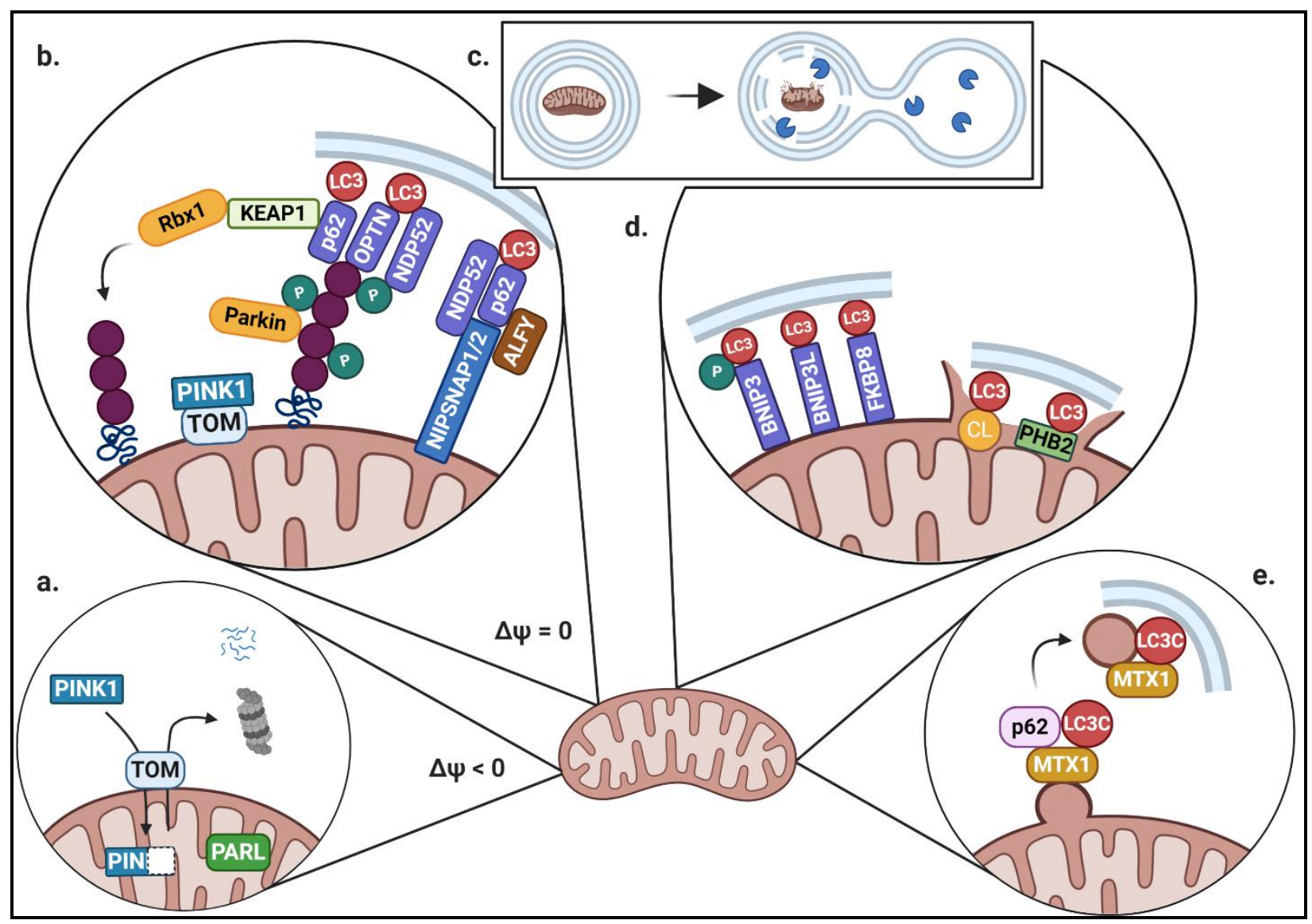

Figure 4: Mitophagy pathways. a. Under basal conditions, PINK1 is translocated into the mitochondrial matrix where it is cleaved into a smaller fragment by PARL and subsequently released into the cytosol where it is degraded by the proteasome. $\mathbf{b}$. The PINK1/Parkin-dependent pathway: when mitochondria are depolarized, PINK1 interacts with the TOM complex to phosphorylate ubiquitin and recruit Parkin, which in turn ubiquitinates OMM proteins (ubiquitin in purple). In the absence of Parkin, p62 can recruit KEAP1 which in turn recruits the E3 ubiquitin ligase Rbx1 to ubiquitinate OMM proteins. Autophagy receptors represented here by NDP52 and OPTN are recruited to the ubiquitinated OMM proteins where they link mitochondria to the autophagosome membrane through interactions with LC3. Similarly, NIPSNAP1 and NIPSNAP2 are stabilized on the OMM when mitochondria are depolarized, where they recruit mitophagy receptors such as NDP52 and p62, as well as the scaffolding protein ALFY, which interact with ATG8 proteins on the autophagosome membrane. c. Mitochondria are engulfed in double membrane vesicles called autophagosomes which fuse with lysosomes to mediate mitochondria turnover. $\mathbf{d}$. PINK1/Parkin-independent mitophagy: OMM bound mitophagy receptors, such as BNIP3L and FKBP8 interact with LC3 on the autophagosome membrane. CL and PHB2 in the IMM are also capable of binding to LC3 to mediate recruitment of mitochondria to the autophagosome. e. Piecemeal 
mitophagy: the OMM protein MTX1 interacts with LC3C and p62 to deliver MTX1 positive mitochondrial vesicles to the autophagosome.

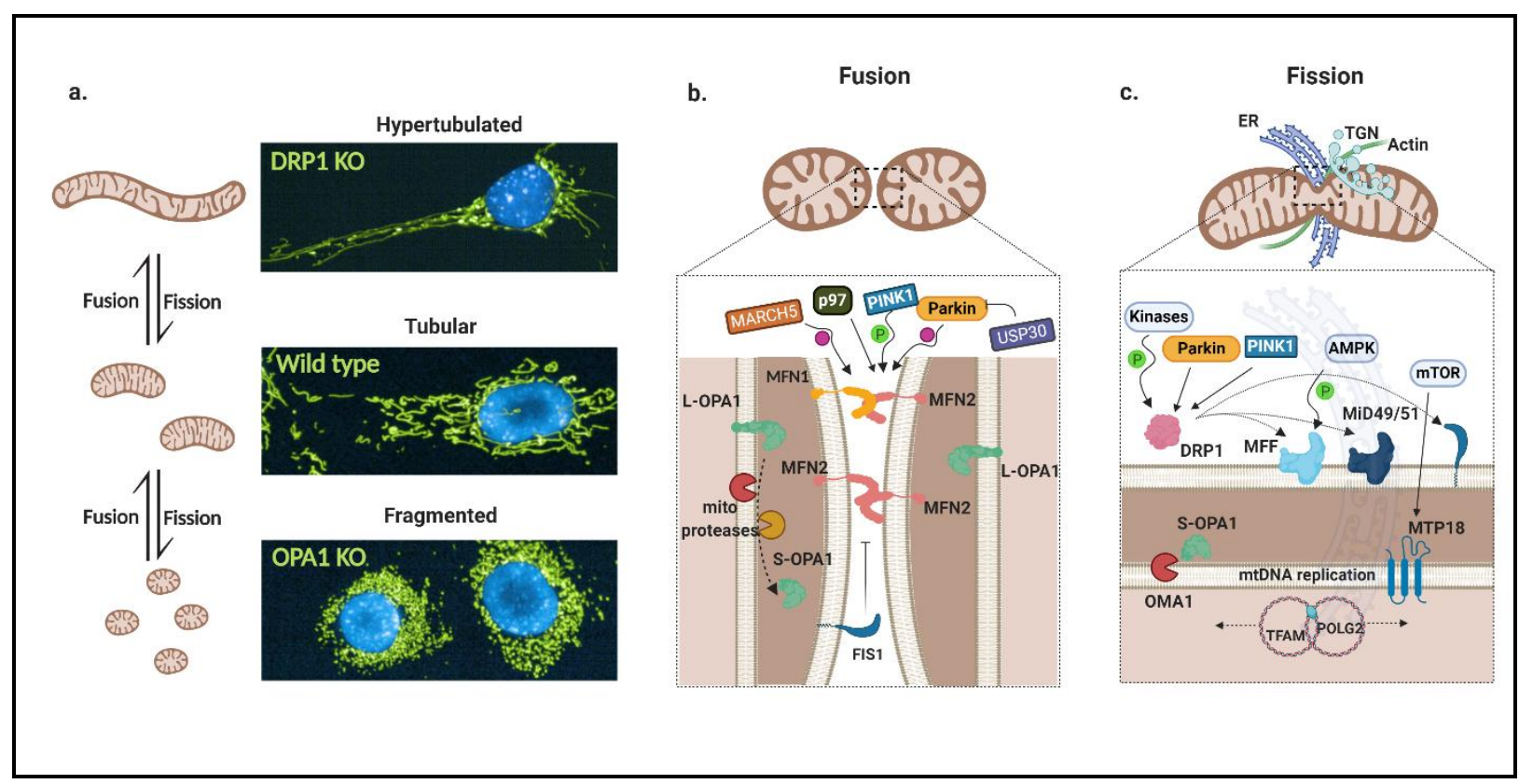

Figure 5: Mitochondrial morphology regulation. a. mitochondrial morphology is maintained by a balance between mitochondrial fission and fusion. Inhibition of mitochondrial fission (via DRP1 $\mathrm{KO}$ ) results in hypertubulated mitochondria, while inhibition of mitochondrial fusion (via OPA1 KO) results in fragmented mitochondria. Mitochondria (green) and nuclei (blue) labeled in fibroblasts imaged by confocal microscopy. b. Mitochondrial fission: DRP1 binds to its receptors MFF or MiD49/51 at the OMM at sites of contact with the endoplasmic reticulum (ER) and actin. Trans-golgi network (TGN) completes mitochondrial fission downstream of DRP1. At the IMM, MTFP1 contributes to IMM fission, which occurs coincident with mtDNA replication mediated by TFAM and POLG2. S-OPA1 accumulation generated by OMA1 accelerates fission. c. Mitochondrial fusion: Dynamin-like GTPases MFN1/2 and OPA1 (L-OPA1) execute OMM and IMM fusion, respectively, and are regulated by posttranslational modification by ubiquitination (MARCH5, p97, Parkin) or deubiquitination (USP30), phosphorylation (PINK1) or proteolytic cleavage by OMA1 and YME1L (mitoproteases). FIS1 antagonizes fusion at the OMM. 


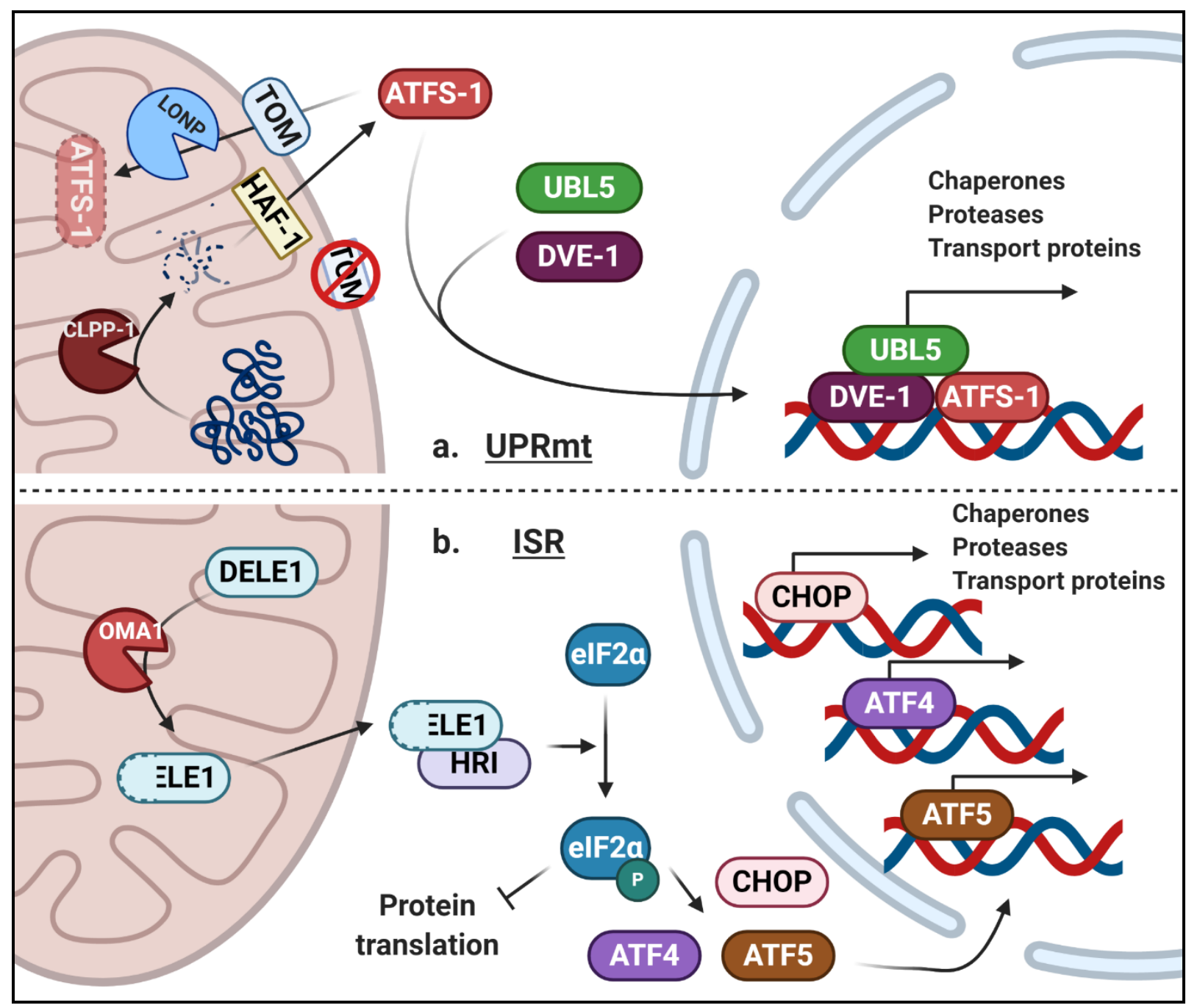

Figure 6. Mitochondria-to-Nucleus stress response. a. Mitochondrial Unfolded Protein Response (UPRmt): The transcription factor ATFS-1 is normally transported into the mitochondria where it is degraded by the mitoprotease LONP in C.elegans. Aberrant proteins are degraded by CLPP-1 and the resulting peptide fragments are released to the cytosol through the matrix peptide exporter, HAF-1. These peptides, together with mitochondrial import impairment promote the nuclear translocation of ATFS-1, UBL5 and DVE-1 to initiate transcription of chaperones, proteases and transport proteins. b. Integrated Stress Response (ISR): In mammals, mitochondrial DELE1 is cleaved by OMA1, and subsequently translocates into the cytosol where it interacts with and activates HRI. HRI phosphorylates elF2a to inhibit cytosolic protein translation and to activate the transcription factors CHOP, ATF4 and ATF5 to initiate stress response gene expression. 